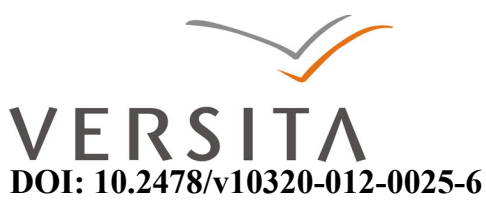

\title{
“CONTENDING WITH THE FRETFUL ELEMENT": SHAKESPEARE AND THE (GENDERED) GREAT CHAIN OF BEING
}

\author{
GYÖRGY E. SZÖNYI \\ University of Szeged; \\ Central European University, Budapest, \\ 6722-H Szeged Egyetem u. 2., Hungary \\ geszonyi@freemail.hu
}

\begin{abstract}
E. M. W. Tillyard's short but seminal book, The Elizabethan World Picture made its appearance as a ground-breaking work in the mid-1940s. It successfully adapted Arthur O. Lovejoy's discovery of the Great Chain of Being as the central idea and metaphor of the premodern world picture for English Renaissance culture and literature, offering a key to understanding the often unfamiliar and obscure natural philosophy and metaphysics behind its works of art and literature. The concept of the Great Chain also led to Shakespeare being seen as a supporter of a conservative order in which religious, moral, philosophical, and scientific notions corresponded with each other in a strict hierarchy. The poststructuralist turn unleashed a severe attack on Tillyard and his legacy. As Ewan Fernie in a recent book on the Renaissance has diagnosed: "Now, after the theoretical overhaul, the notion of an ultimately authoritarian Renaissance has been thoroughly revised. In place of Tillyard's full-fledged and secured physical, social and cosmological system, more recent critics tend to posit a conflicted and constantly negotiated culture with no essential pattern". But what has happened to the idea of the Great Chain of Being, which, without doubt, played a major role in the Renaissance world picture and provided a basic knowledge about the elements? In my paper I am going to revisit some aspects of this world picture and examine how Shakespeare related to this (more often than not) in a subversive way, while still remaining within the boundaries of this organic and proto-modern system. Since the concept of the elements had gender aspects, too, I will also focus on the question of how proto-modern natural philosophy theorised about the dichotomy, antagonism, and the cooperation of male and female principles.
\end{abstract}

Keywords: gender, Great Chain of Being, premodern natural philosophy, romances, Shakespeare, theology 
Shakespeare saw the relationship of humans to the elements in a variety of ways, ranging from hopeless struggle to glorious and dignified victories. When Lear stands against the storm he seems to combine both attitudes while

Contending with the fretful elements;

Bids the wind blow the earth into the sea,

Or swell the curled waters 'bove the main,

That things might change or cease; tears his white hair,

Which the impetuous blasts, with eyeless rage,

Catch in their fury and make nothing of;

Strives in his little world of man to outscorn

The to-and-fro-conflicting wind and rain.

This night, wherein the cub-drawn bear would couch,

The lion and the belly-pinched wolf

Keep their fur dry, unbonneted he runs,

And bids what will take all. (King Lear 3.1.4-15)

The playwright's views seem to have been motivated on the one hand by his own personal disposition, which underwent radical changes during his career. On the other hand, equally importantly, he was confronted by the received theological, philosophical, and scientific ideas of his time which he treated sometimes with approval, sometimes subversively. From all this it follows that one should not expect a homogeneous worldview to emerge from the study of "Shakespeare and the elements"; rather, what follows will corroborate what Fernie recently summarized as follows: "the twenty-first century Renaissance has to come to be envisaged as an intensely turbulent period, in which construction of class, race, and gender were negotiated, in which doubts and anxieties freely circulated" (Fernie 2005:1).

This current view has radically displaced E. M. W. Tillyard's position in The Elizabethan World Picture (1943), which was considered to be ground-breaking in the mid-1940s. It successfully adapted for English Renaissance culture and literature Arthur O. Lovejoy's (1936) history of ideas and his concept of the "Great Chain of Being" as the central notion and metaphor of the premodern world picture, something that would offer 
a key to understanding the often unfamiliar and obscure natural philosophy and metaphysics behind the works of art and literature (on Lovejoy's concept see Wilson 1987). The concept of the Great Chain also led to Shakespeare being seen as a supporter of a conservative order in which religious, moral, philosophical, and scientific notions corresponded to each other in a strict hierarchy.

The poststructuralist turn launched a severe attack on Tillyard and his legacy. As Fernie diagnoses: "Now, after the theoretical overhaul, the notion of an ultimately authoritarian Renaissance has been thoroughly revised. In place of Tillyard's full-fledged and secured physical, social and cosmological system, more recent critics tend to posit a conflicted and constantly negotiated culture with no essential pattern" (Fernie: ibid.). But what has become of the idea of the Great Chain of Being, the links of which, without doubt, played a major role in the Renaissance world picture and provided a basic knowledge about the elements?

In my paper I am going to revisit some aspects of this world picture and examine how Shakespeare related to it - more often than not in a subversive way, while still remaining within the boundaries of this organic and proto-modern system. Since the concept of the elements had gender-aspects, too, I will also focus on the question of how proto-modern natural philosophy theorised about the dichotomy, antagonism, and cooperation of male and female principles.

\section{II}

The most convenient starting point is to revisit Tillyard's key propositions. According to the author's own description, The Elizabethan World Picture was a byproduct of his other book, Shakespeare's History Plays (1944), in which he tried to describe the political order of the Elizabethan age, only to soon discover that this notion of order was much more general - through the idea of the chain and correspondences it connected the world of humans to a larger, cosmic system. It should cause no surprise that today Tillyard's analysis of the history plays is also severely attacked and labelled as exhibiting a false essentialism, having been forged among the last efforts of British imperialism and in the context of a nationalistic upsurge resulting from the struggle against Nazi Germany in the 1940s (see for example Holderness [1992]). 
Undoubtedly, Tillyard was looking for "the notions about the world and man which were quite taken for granted by the ordinary educated Elizabethan; the utter commonplaces too familiar for the poets to make detailed use of except in explicitly didactic passages, but essential as basic assumptions and invaluable at moments of high passion." (Tillyard 1943: vii-viii). The programme of the book was accordingly:

\footnotetext{
My object then is to extract and expound the most ordinary beliefs about the constitution of the world as pictured in the Elizabethan age and through this exposition to help the ordinary reader to understand and to enjoy the great writers of the age. (ibid.)
}

Today's readers may sceptically gloss this ambition by remarking that the utter commonplaces are not necessarily the most enjoyable aspects of the great writers of the past. It remains a fact, however, that when one is reading literature from remote periods, alongside local and occasional humour, it will always be the references to world view and scientific ideas that will be the least accessible to the modern reader or theatregoer. In this respect Tillyard is still useful as an easy introduction to the theological, philosophical and scientific theories of the early modern period. After all, the notion of predestination, the medical concepts about the four humours and the temperaments of humans, and the correspondences between the macrocosm and the microcosm are not readily available to the modern and postmodern audience.

Recent Renaissance and Shakespeare criticism has taught us to realise in what subtle and intricate ways the great masters of the period were subverting the received ideas of the age. At first reading Tillyard seems to have neglected these subversions and to picture the Elizabethans en bloc as traditionalists and conservatives. I think it is time to admit that this criticism is not entirely fair. In fact, one of Tillyard's recurrent concerns is to prove that their thinking and behaviour was far more manifold and versatile, even paradoxical, than we might imagine. When Tillyard wrote, there was a tendency to interpret the English Renaissance as a primarily modern and secular age, so he tried to pinpoint its strong religious and theological concerns as well, highlighting that under the banner of a unifying ideology very contrarian ideas and activities could be accommodated. For example, "Queen Elizabeth translated Boethius, Raleigh was a theologian as well as a discoverer, and sermons were as much a part of an ordinary 
Elizabethan's life as bear-baiting" (The Elizabethan, 3). After the vogue of New Historicism and Cultural Materialism, one has to recognise that these aspects have again been forgotten about, or at least that everything that occupied the Elizabethans has been interpreted in the context of a racial, gender, and ideological power struggle in which no place has been left for the desire and ambition to attain peace, harmony, understanding, or good will.

In this respect Tillyard's book is a useful reminder. And, furthermore, it is also not entirely true the he was completely blind to subversive tendencies against the received, commonplace ideas of the age. He repeatedly emphasised that the serious ceremoniality of the Middle Ages had by the time of the Renaissance often degenerated into farce, and that though "the general medieval picture of the world survived in outline into the Elizabethan age, its existence was by then precarious" (ibid., 8). Among the new challenges he listed the new, subversive political ideology proposed by Machiavelli, the scientific revolution heralded by Copernican astronomy, and the new commercialism that was hostile to medieval stability.

All this is not enough to absolve Tillyard from under the charge of having created a "grand narrative," and having by and large disregarded many intriguing features of the Elizabethan world picture. The problematic nature of saying anything definitive about this period has become dramatically visible recently, since the Early English Books Online project has made available the full text of all English printed books up to the end of the seventeenth century. While EEBO is an invaluable research tool and has democratised early modern cultural and literary research, its existence has created two main problems. Firstly, as anyone can now access a rare book library of over a hundred and thirty thousand works on his/her computer, even the illusion of gaining a relatively comprehensive knowledge of the printed works of a period has vanished. From now on one can never be sure how the content of these books which are now readily available in EEBO ought to have modified the results of earlier research projects carried out at a time when, because of the physical limitations of the previous researcher could not be checked. From this uncertainty follows another necessity. From now on any interpretative analysis has to be accompanied by an extremely meticulous documentation of the consulted sources, and one has to bear in mind that the results have their validity only 
within this circle of sources. All in all, the information boom has not only widened, but at the same time also limited, our epistemological possibilities.

\section{III}

Compared with the almost limitless source materials burdening the cultural historian of the Elizabethan Age, the Shakespeare scholar is in a relatively easy situation since his/her primary sources are limited to - more or less - 38 plays, 154 sonnets, two longer epics and a few other poems. It is a manageable amount of text in which to look for references to the elements, their cosmic order and their influence on human nature. The hard part is to identify their proper contexts, and one should bear in mind that the identification will never be independent of the biases of the interpreter.

With the help of a concordance program it is easy to collect the occurrences of the word "elements" in Shakespeare's oeuvre. We have 23 items, out of which 8 have meteorological meanings, referring to the wild elements, that is stormy weather. The obvious examples are from King Lear ("I tax not you, you elements, with unkindness," 3.2.16) and from The Tempest ("You are a / counsellor; if you can command these elements to / silence, and work the peace of the present, we will / not hand a rope more," 1.1.20-22). Likewise, when Pericles mourns over the dead body of Thaisa, he breaks out: "the unfriendly elements / Forgot thee utterly" (3.1.57-8).

The rest of the occurrences refer in one way or another to the four elements which - according to the premodern world picture - were the building blocks of the material universe. It should not be surprising that Shakespeare's frame of reference is the received protomodern system in which there are only four elements - earth, water, air, and fire whose pre-ordered place is at the bottom of the Great Chain of Being. Since they are the constituents of the whole visible and material universe as well as the human body, they are of the utmost importance in establishing the links and correspondences between the macro- and microcosms. This is what Pericles recognizes when he welcomes his newborn daughter, Marina, into this world:

Thou hast as chiding a nativity

As fire, air, water, earth, and heaven can make,

To herald thee from the womb. (Per 3.1.32-34) 
So also Toby Belch asks in Twelfth Night: "Does not our life consist of the / four elements?" (2.3.9-10).

The structural role of these elements in the premodern world picture can be seen in countless Renaissance illustrations, from popular almanacs and calendars to complicated works of natural philosophy. FIG. 1 dates from the Middle Ages.

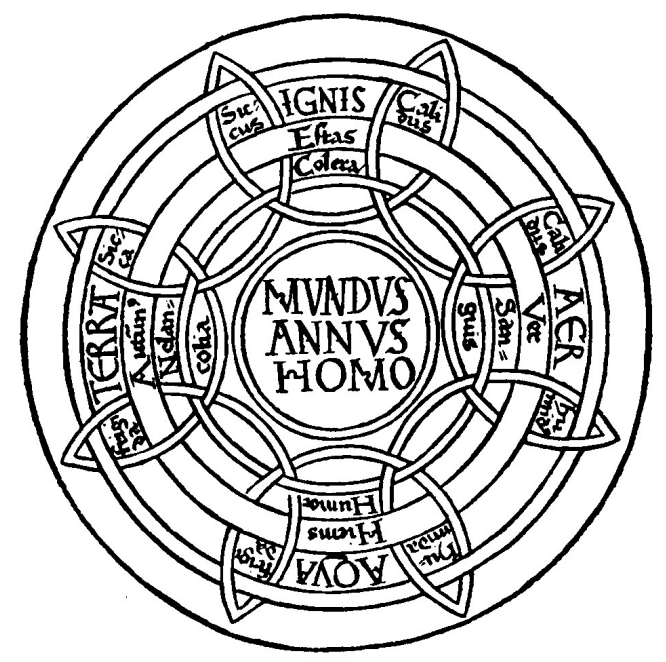

FIG. 1 Isidore1472-Tetrad

It is the famous tetrad of Isidore of Seville, representing the four elements, the four qualities (moist-dry-cold-hot), the four seasons and the four human temperaments (sanguine-choleric-phlegmatic-melancholic).

According to this world view, the human temperaments are the consequence of the different proportions of the elements and qualities in the individual body.

One of the popular schoolbooks of Shakespeare's time, Robert Recorde's Castle of Knowledge, described the four elements as follows:

And these four, that is, earth, water, ayer, and fyre, are named the four elements, that is to say, the fyrste, symple and originall matters, whereof all myxt and compounde bodies be made, and into which all shall tourne againe. (Recorde 1556: 6)

Henry Peacham in his emblem book, Minerva Britanna (1612), also described the composition of the human body as consisting of four elements (FIG. 2 - some more 
books by contemporaries of Shakespeare explaining the system of the elements and humours: Davies 1603; Walkington 1607; Nemesius-Wither 1636; etc.):

Of heate and cold as is the Aire composed,

So likewise man we see breath's hot and cold,

His bodie's earthy: in his lunges inclosed,

Remaines the Aire: his braine doth moisture hold,

His heart and liver, doe the heate infold:

Of Earth, Fire, Water, Man thus framed is,

Of Elements the threefold Qualities. (Peacham 1612: 190)

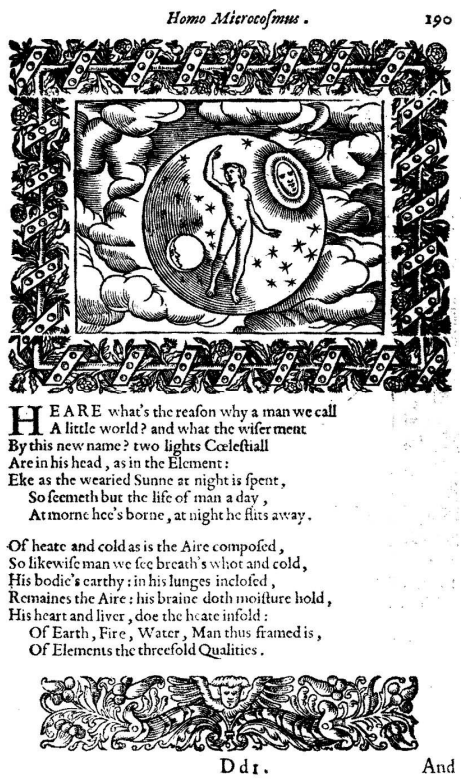

FIG. 2 Peacham1612-Homo microcosmus

Apart from the meteorological connotations, Shakespeare's references to the elements are all related to the system of the abovementioned tetrads which result from the combination of these four constituents. But since Shakespeare is not primarily interested in natural philosophy, rather in the human condition, the elements and qualities are important for him as markers of psychological character and temperament. One of the most elaborate and finest examples may be found in Sonnets 44 and 45 . The former is about earth and water: 
If the dull substance of my flesh were thought,

Injurious distance should not stop my way;

For then despite of space I would be brought,

From limits far remote where thou dost stay.

No matter then although my foot did stand

Upon the farthest earth removed from thee;

For nimble thought can jump both sea and land

As soon as think the place where he would be.

But ah! thought kills me that I am not thought,

To leap large lengths of miles when thou art gone,

But that so much of earth and water wrought

I must attend time's leisure with my moan,

Receiving nought by elements so slow

But heavy tears, badges of either's woe.

Earth and water, the "dull and slow elements", make up the body, as opposed to air and fire, which pertain to thought and intelligence. While the body cannot defeat distance "to jump both sea and land" in order to be with his lover, Sonnet 45 assures the lover that

The other two, slight air and purging fire,

Are both with thee, wherever I abide.

Air corresponds here to thought and fire to desire. And as the two escape to the lover, the speaking self, composed of the four elements but left with only two, "Sinks down to death, oppress'd with melancholy."

Melancholy results, according to contemporary medical theory, from the disturbed balance of the elements and humours of the body. As Timothy Bright wrote in his treatise on melancholy - just a few years before Shakespeare appeared on the English stage:

It was declared that the quantitie of melancholie should be least in the just temper of bloud of al the other parts, saving choler, which naturall proportion and rate when it exceedeth, then is the bodie turned into a disposition melancholicke by humour. (Bright $1586: 25)$ 
Another contemporary, Jacques Ferrand, a French physician, whose book, Erotomania, or a Treatise Discoursing of the Essence, Causes, Symptomes, Prognosticks, and Cure of Love, or Erotique Melancholy was published in English, discussed the specifics of love-melancholy. About its symptoms he wrote:

Yet I grant that love is the ground and Principall cause of all our Affections, and the Abstract of all the Passions and perturbations of the mind. [...] By reason of these perturbations, the bloud becomes adust, earthy, and Melancholy, as in all other violent passions, except joy, by which meanes diverse have fallen into strange and desperate diseases, growing Melancholy, Foolish, Mad, Cynicall, Wolvish: as the learned Avicen reports, in his caput de Amore. (Ferrand, 10-11)

In this context we could immediately examine Jacques, Hamlet, or Malvolio; however, let me return to Shakespeare's sonnets. In Sonnet 45 the speaking self recovers from his melancholy state when he is reunited with his missing two elements:

\footnotetext{
Until life's composition be recured

By those swift messengers return'd from thee,

Who even but now come back again, assured

Of thy fair health, recounting it to me...
}

But, of course, a person in love cannot be cured so easily. He deliberately brings himself down, because his passion compels him to send his better elements back again to his lover: "I joy; but then no longer glad, / I send them back again and straight grow sad." Yet, there is hope. Because, as we know from Berowne in Love's Labour's Lost, love catalyses the workings of the elements in the body to achieve wondrous powers:

But love, first learned in a lady's eyes,

Lives not alone immured in the brain;

But, with the motion of all elements,

Courses as swift as thought in every power,

And gives to every power a double power,

Above their functions and their offices. (LLL 4.3.326-32) 
Most of Shakespeare's references to the elements refer to the composition, balance, or disturbance of these four in humans, thus determining their character and temperament.

His life was gentle, and the elements

So mix'd in him that Nature might stand up

And say to all the world 'This was a man!'

says Anthony about Caesar over his dead body (JC 5.5.73-75). When Cleopatra commits suicide and calls to the already dead Anthony, the image she uses is very similar to that of Sonnet 45 mentioned above:

husband, I come [...]

I am fire and air; my other elements

I give to baser life. (Ant. 5.2.287-90)

But the same image can also be used about an animal. When Lewis the Dauphin in Henry $V$ praises his horse, he says,

\section{It is a beast for}

Perseus: he is pure air and fire; and the dull

elements of earth and water never appear in him, but

only in Patient stillness while his rider mounts

him: he is indeed a horse... (H5 3.7.20-24)

The four elements not only provided the foundation for early modern medicine and through the humoral system for psychology too, but also connected to astrology and alchemy (the latter nicknamed as "inferior astronomy"), these two "cosmic sciences" being closely connected with theories about man's spiritual and bodily well being, fate and fortune. On the title page of the already mentioned schoolbook, Recorde's Castle of Knowledge (FIG. 3), the fortress - its strength signified by the keyholes to which the student has to find the proper keys - is flanked by two allegorical female figures, Destiny 
and Fortune. These are the rulers of life, unless one, by the help of knowledge and wisdom (Urania), can overcome Fortune's power:

To KNOWLEDGE this Trophy set,

All learnings friends will it support,

So shall their name great honour get,

And gaine great fame with good report.

Though spitefull Fortune turned her wheele

To staye the Sphere to Uranye,

Yet doth this Sphere resist that wheele,

And fleeyth all fortunes villanye.

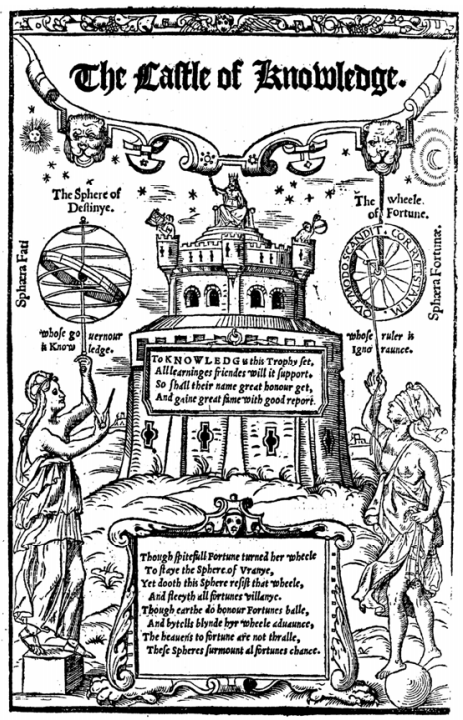

FIG. 3 Recorde1556 Castle of Knowledge

Premodern notions of alchemy relied heavily on the theories of the four elements as well as the Great Chain of Being. The transmutation of the elements from a base and corrupt state to a purified and perfect one (the Philosopher's Stone, or quinta essentia) also meant ascension along the chain of being. Furthermore, it is interesting to notice how references to sexuality, bodily and spiritual union were also embedded in these speculations, thus opening up a gender aspect in these cultural representations.

The English mystical philosopher, Robert Fludd, one year after Shakespeare's death published his monumental Utriusque cosmi historia (The History of the Two 
Worlds - i.e. macrocosm and microcosm, Oppenheim, 1617) in which one of his meticulous diagrams describes the elemental connections of the Great Chain of Being as follows (FIG. 4, Fludd 1617: 4-5): the cloud, representing God, is chained to a beautiful naked woman, who is the allegorical personification of Nature, standing on two elements: earth and water. In the middle of the cosmic spheres there is a small globe on which a monkey sits, chained to Lady Nature. The ape stands for Art, which is capable of imitating Nature by the help of the human sciences and "Artes liberaliores," surrounding the Ape-artist. Shakespeare also uses the "Nature's Ape" image when he introduces the Italian Julio Romano as the creator of Hermione's "statue" in The Winter's Tale:

A piece many years in doing and now newly performed by that rare Italian master, Julio Romano, who, had he himself eternity and could put breath into his work, would beguile Nature of her custom, so perfectly he is her ape: he so near to Hermione hath done Hermione that they say one would speak to her and stand in hope of answer. (WT 5.2.106-112)

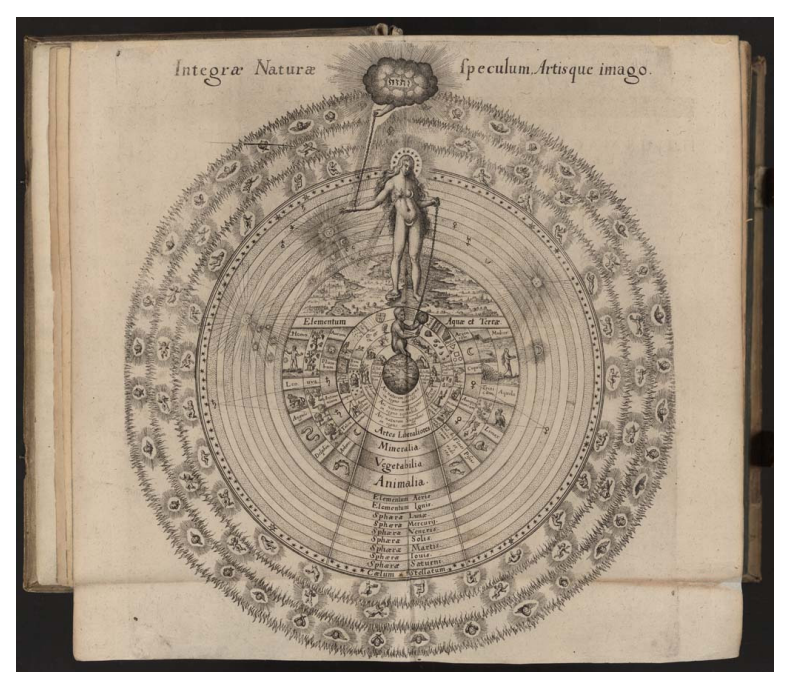

FIG. 4, Fludd 1617 Nature-Art

This artistry also demonstrates that the sculptor is like an alchemist; he can translate the base element earth (in the case of a statue: stone, mineralia) into composite and living human tissue - at least according to the fiction of the play and Pauline, the director-woman of the scene, who presents this magic to the stunned king, Leontes. The magical parallel to the miracle of the sculptor is the creation of the Golem in early 
modern Jewish mysticism (Scholem 1987:101-3; Idel 1988:100-24; 260), or the idea of the homunculus in the works of the magical doctor, Paracelsus (1976: vol 2, 120, 334). As Henry More, the Cambridge Platonist, summarized Paracelsus' notion:

\footnotetext{
That there is an artificiall way of making an Homunculus, and that the Fairies of the woods, Nymphs and Giants themselves had some such originall, and that these Homunculi thus made will know all manner of secrets and mysteries of art, themselves receiving their lives, bodies, flesh, bone, and blood from an artificiall principle. (More $1656: 46)$
}

Medieval and Renaissance alchemy consisted of two practices. One was the chemical transmutation which aimed at changing lower quality elements through purging and purification into higher ones (from iron to copper to quicksilver to silver to gold). The other type of alchemy was spiritual, programmed to purify, transform, and elevate the soul into the state of exaltatio (Calian 2010). As is clear from Samuel Norton's illustration of the hermetic transformation in his Mercurius redivivus (Frankfurt, 1630, FIG. 5, reproduced from Jung 1980:240): the raw material is represented by the roots of the tree being anchored in the elements - in the human microcosm it is the body, the corpus. The transmutation turns the quadrat of the elements into a spiritual triangle (roofed by spiritus and anima), which, exalted, will bring forth the beautiful flowers at the top. (The roses indicate that we here encounter a Rosicrucian-inspired symbolism.)

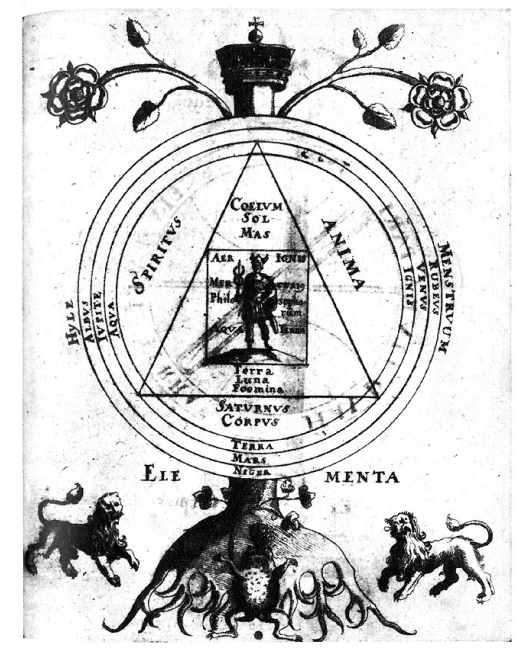

FIG. 5 Norton 1630 
In George Ripley' Compound of Alchemy (1471, published in London, 1591) a description of the chemical exaltation is described in language that could be either religious or that of a Shakespearean play:

\footnotetext{
For like as soules after paines transitorie

Be brought to Paradise where ever is joyfull life,

So shall our Stone (after his darknes in Purgatorie)

Be purged and joyned in Elements withouten strife,

Reioyce the whitenes and beautie of his wife...

(quoted by Nicholl 1980:203)
}

The expression "wife" reminds us that paradigmatically these alchemical transformations were described as sexual exaltatio and visually the process was represented as different phases of coitus (FIG. 6: Rosarium philosophorum, MS from 1550, reproduced from Roob 1997:453).

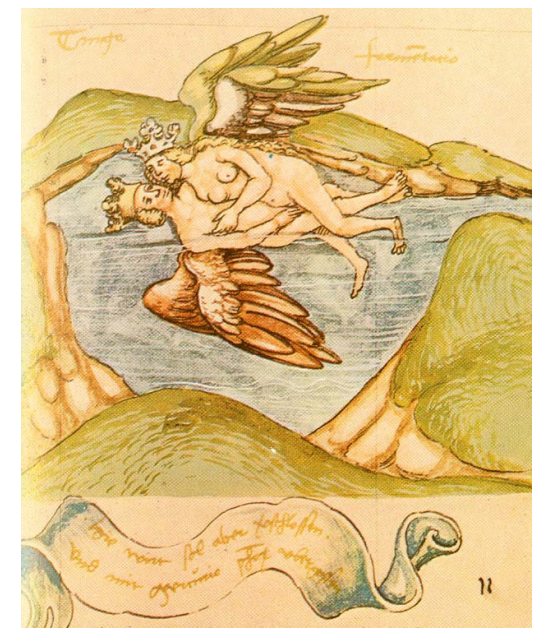

FIG. 6: Alchemy-Rosarium-1550-11-K\&Q fermentation

All throughout Shakespeare's career we find various references to chemical and spiritual alchemy. In Romeo and Juliet the Friar speaks the language of Paracelsian natural philosophy when calling the earth "Nature's mother," which brings forth "children of divers kind" (cf. Rom 2.3.8-27 - for this and the following references I rely on Nicholl 1980, passim). In Sonnet 5 the destructive working of Time is represented by 
the image of Nature turning from Summer to the bareness of hideous Winter, yet an alchemical type of distillation can preserve the essence of summer - instead of roses we have rosewater perfume:

Then, were not summer's distillation left,

A liquid prisoner pent in walls of glass,

Beauty's effect with beauty were bereft,

Nor it nor no remembrance what it was:

But flowers distill'd though they with winter meet,

Leese but their show; their substance still lives sweet.

This preserving act of distillation and producing the "essence" of things can be achieved in three ways. One is alchemical transmutation which aims to produce the mystical quinta essentia. Another procedure is procreation, which carries on the essence of the parents as a result of the sexual union:

Then let not winter's ragged hand deface

In thee thy summer, ere thou be distill' $\mathrm{d}$ : [ . . ]

That use is not forbidden usury,

Which happies those that pay the willing loan;

That's for thyself to breed another thee, $[\ldots]$

Then what could death do, if thou shouldst depart,

Leaving thee living in posterity?

- asks Shakespeare in Sonnet 6.

As Charles Nicholl has argued, alchemical symbolism, even alchemicalemblematic theatricality, become most complex and dense in the last plays, the romances. In The Chemical Theatre he analysed in detail the cave-scene in Cymbeline (4.2 - Nicholl 1980:225-36), where Imogen in disguise seemingly dies of a magical potion; in the meantime the two princes in disguise kill the wicked Cloten in disguise - wearing the clothes of Posthumus, Imogen's husband -; and when Imogen wakes from her sleep, she thinks the beheaded body of Cloten is that of her beloved and smears his blood onto her face and embraces him in a deadly sexual hug. This is the beginning of the alchemical transmutation: Imogen enters the cave in the forest, penetrates matter and finds her 
disguised royal brothers. The discovery and the ensuing horrifying events (in the alchemical narratives: regicide followed by copulation in the coffin [FIG. 7 - Johannes Mylius, Philosophia reformata, Frankfurt, 1622 - reproduced from Klossowski de Rola 1988:174] followed by death and regeneration) will lead to the final recognition and restoration when the Philosopher's Stone, or the elixir, or the quinta essentia is produced.

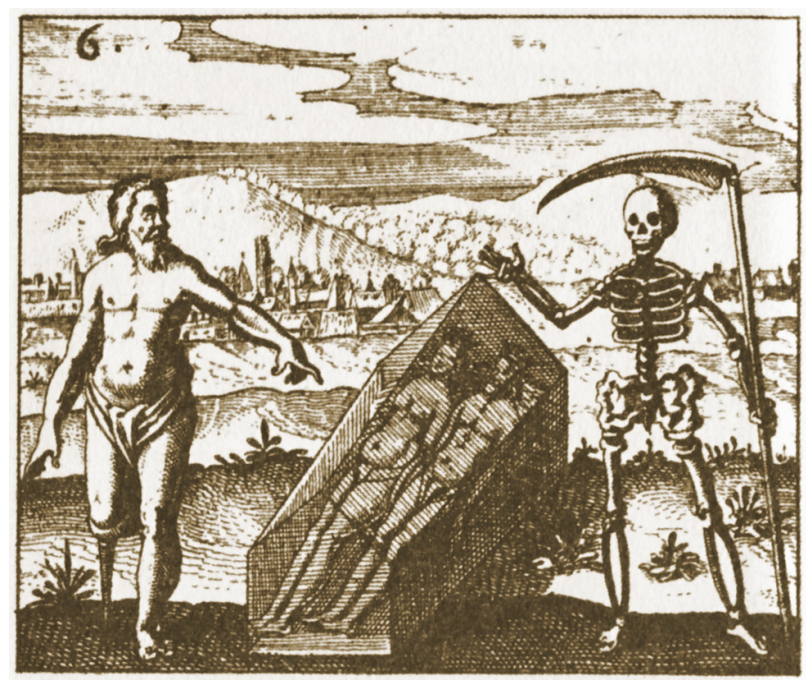

FIG. 7 Alchemy-Mylius-Philos Reformata-1622-K\&Q in coffin

In Leonhard Thurneisser's alchemical study, Quinta essentia, the main catalyzer of the Work, the spirit of Mercury (quicksilver), is a beautiful naked woman (FIG. 8 reproduced in Jung 1980: 189). In Cymbeline Imogen is this Anima Mercurii who brings about the transformation of all the male characters: the king, his sons, Posthumus, Bellarius, even the wicked Iachimo. 


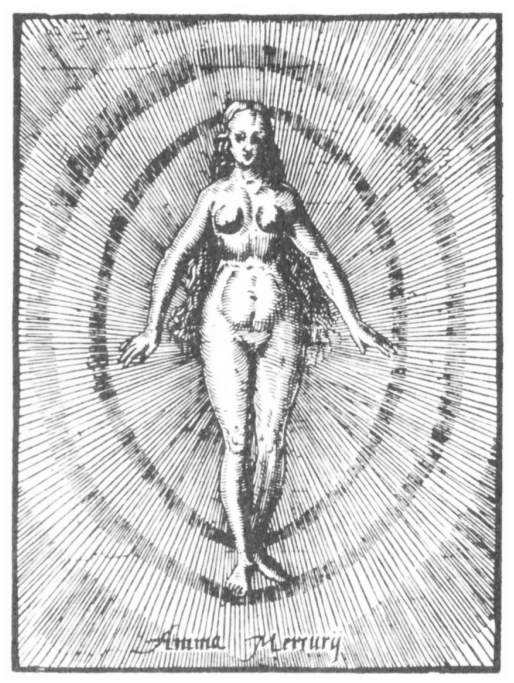

FIG. 8 Alchemy-Thurneisser-Qessentia-1576-Anima mercurii

As has been mentioned, in alchemy there are two parallel processes taking place. On the one hand the elemental matter is transmuted into gold or elixir, on the other hand, the operator, the alchemist, also goes through a spiritual transmutation. The gender roles in the process are traditional: the active, male principle is in focus, represented by the King, the bridegroom, the Sun, gold, the lion, - and the alchemist himself is invariably a man. The female principle is also essential in the process as foundation (earth, Nature), or catalyzer (the Queen, the bride, Moon, silver, the virgin, the whore). The most elaborate allegorical narrative of these processes is to be found in Johann Valentin Andreae's Chimische Hochzeit (1626, English translation by E. Foxcroft, 1690) and Michel Maier's Themis aurea (1618, English translation 1656), but of course, as mentioned above, one could also rely on native English alchemical texts, such as Ripley's Compound of Alchemy, [Pseudo] Roger Bacon's The Mirror of Alchimy (1597) and many others finally republished in the huge anthology of Elias Ashmole, the Theatrum Chemicum Britannicum (1652). All of these transmitted the above mentioned traditional approach to gender hierarchy, and Shakespeare was no exception when he used alchemical imagery.

It is all the more interesting that on one occasion the Bard radically subverted the traditional understanding of alchemy, in a way similar to his technique of transgressing tradition-based emblematic imagery (on this see Szönyi 2003: passim). At the end of The Winter's Tale there takes place a magic transmutation of the "stone statue" of Hermione 
into a living, organic being: "Who was most marble, there changed colour" (5.2.89). There is a certain irony in the situation concerning Leontes: the King/Lion who comes to be exalted into Sun/Gold when he does not notice the trick played on his senses. But if we take the emblematic setting seriously, we are satisfied to see that he comprehends and accepts the moral lesson:

I am ashamed: does not the stone rebuke me

For being more stone than it? O royal piece,

There's magic in thy majesty. (5.3.37-9)

Who is the Royal Piece then, the Magnum Opus? Hermione, the perfect woman who did not need to change at all, and who represented superiority from the beginning. And who is the alchemist then, the operator, who also undergoes spiritual exaltatio? In this Shakespearean scene the two functions, the active operator and the spiritually transmuted person, are separated, or doubled. There is the male king who badly needs renovation and regeneration, but on the other hand the operator is again a woman, Paulina. It has been noticed by several critics that at the end of The Winter's Tale Leontes in fact is definitely pushed into the background behind the dignified and celebrated female interactions among Paulina, Hermione, and the lost-found Perdita.

\section{IV}

Because of the constraints of this paper I cannot pursue further examples; rather, I will try to come to some conclusions. It is well known regarding Shakespeare that he used the commonplace ideas of the premodern world picture in a creative way, often arriving at perfect ambiguities, by which he at the same time asserted and subverted the received knowledge. As for his attitude to the elements, the Great Chain of Being, or chemical/spiritual transmutation, he does not seem to have challenged the theories of Aristotle, Galen, and the medieval alchemists. Although in this paper I could not discuss this aspect, he also seems to have believed in forces greater than humans determining their lives: fate, providence, and fortune. At the same time, his attitude is by no means submissive or fatalistic. Some of his characters try to outwit nature as much as others abide by her rules. And the poet is on neither side; he can equally endorse both attitudes. 
When Shakespeare comes to subvert received ideas, he often uses the emblematic way of expression, using well-known images in bonam partem and in malam partem (see Daly 1993; Szönyi 2000 and 2003). This is how Richard II is associated with the setting sun, or the daughter of Antiochus in Pericles turns from the "fruit of a celestial tree" and a "fair glass of light" into a "glorious casket stor'd with ill," not to mention being "a fair viol [...] played upon before [her] time, / Hell only danceth at so harsh a chime" (1.1.22, 76-85). As we have been able to see in the case of The Winter's Tale (and further examples could be multiplied from other plays), Shakespeare skilfully used this subversive technique to undermine traditional gender hierarchies too.

Contra many (post)modernist opinions, I think that Shakespeare is exciting and inspiring even today, precisely because he manages to do two things in parallel: while subverting and uncovering the falsity of a disintegrating world picture and the hypocrisy of its value system, he presents these with such poetic power that it evokes a feeling of nostalgia, and of admiration too.

\section{References}

[Andreae, Johann Valentin.] 1690 (original German: 1626). The Hermetick Romance or

The Chymical Wedding Written by Christian Rosencreutz. Translated by E. Foxcroft, late Fellow of Kings College Cambridge. London.

Ashmole, E. (ed.). 1652. Theatrum Chemicum Britannicum. Containing Severall

Poeticall Pieces of our famous English Philosophers. London.

[Pseudo] Bacon, R. 1597. The Mirror of Alchimy. London.

Bright, T. 1586. A Treatise of Melancholie Containing the Causes Thereof, \&

Reasons of the Strange Effects it Worketh in Our Minds and Bodies. London:

Thomas Vautrollier.

Calian, G.-F. 2010. “Alkimia Operativa and Alkimia Speculativa. Some Modern

Controversies on the Historiography of Alchemy" in K. Szende and J. Rasson

(eds.). Annual of Medieval Studies At Ceu 10. Budapest: CEUPress, pp.166-90.

Daly, P. 1993. Teaching Shakespeare and the Emblem. A Lecture and Bibliography.

Wolfville: Acadia University.

Davies, J. 1603. Microcosmos. The Discovery of the Little World, with the Government Thereof. London.

Fernie, E. et al. (eds.) 2005. Reconceiving The Renaissance. Oxford: Oxford University Press. 
Ferrand, James [Jacques]. 1640. Erotomania, or a Treatise Discoursing of the Essence,

Causes, Symptomes, Prognosticks, and Cure of Love, or Erotique Melancholy. London.

Fludd, Robert. 1617. Utriusque cosmi historia (2 vols). Oppenheim: Theodor de Bry.

Holderness, G. 1992. Shakespeare Recycled. The Making of Historical Drama. London: Harvester.

Idel, M. 1988. Kabbalah. New Perspectives. Yale University Press.

Jung, C. G. 1980 (1953). Psychology and Alchemy. London: Routledge \& Kegan Paul.

Klossowski de Rola, S. 1988. The Golden Game: Alchemical Engravings of the Seventeenth Century. London: Thames \& Hudson.

Lovejoy, A. O. 1936. The Great Chain of Being: A Study of a History of an Idea. Cambridge, Mass.: Harvard University Press (several subsequent editions).

Maier, M. 1656 (original Latin 1618). Themis aurea. The Laws of the Fraternity of the Rosie Crosse. London: N. Brooke.

More, H. 1656. Enthusiasmus Triumphatus, Or, A Discourse of the Nature, Causes, Kinds, and Cure, of Enthusiasme. London.

Nemesius, tr. and ed. G. Wither. 1636. The Nature of Man. London.

Nicholl, C. 1980. The Chemical Theatre. London: Routledge.

Paracelsus, A. Ph. Th. 1976 (1894). The Hermetic and Alchemical Writings. 2 vols. Ed. A. E. Waite. Berkeley: Shambala.

Peacham, H. 1612. Minerva Britanna [collection of emblems]. London. See also: "The Minerva Britanna Project" [Online]. Available: http://f01.middlebury.edu/FS010A/STUDENTS/index.htm.

Recorde, R. 1556. The Castle of Knowledge. London.

Ripley, G. 1591 (1471). The Compound of Alchemy. London.

Roob, A.1997. The Hermetic Museum: Alchemy and Mysticism. Köln: Taschen.

Scholem, G. 1987. Origins of the Kabbalah. Princeton University Press, The Jewish Publication Society.

Shakespeare $=$ OpenSource Shakespeare (www.opensourceshakespeare.com)

Shakespeare, W. 1974. The Riverside Shakespeare. Ed. G. Blakemore Evans. Boston: Houghton Mifflin.

Szönyi, G.E. 2000. "Matching the 'Falles of Princes' and 'Machiavell': Tradition and Subversion in the Historiography and Iconography of Shakespeare's Histories" in Szönyi G. E. \& R. Wymer (eds.). The Iconography of Power: Ideas and Images of Rulership on the English Renaissance Stage (Szeged: JATEPress, Papers in English \& American Studies 8), pp. 5-33.

—. 2003. "The 'Emblematic' as a Way of Thinking and Seeing in Renaissance Culture" 
in E-Colloquia 1.1: <http://ecolloquia.btk.ppke.hu/issues/200301/>.

Tillyard, E. M. W. 1943. The Elizabethan World Picture. London: Chatto \& Windus (and several subsequent editions).

—. 1944. Shakespeare's History Plays. London: Chatto \& Windus.

Walkington, T. 1607. The Optick Glasse of Humors. Or the Touchstone of a golden temperature, or the Philosophers Stone to make a golden temper. Wherein the four complections Sanguine, Cholericke, Phlegmaticke, Melancholicke are succintly painted forth... London.

Wilson, D. J. 1987. “Lovejoy’s the Great Chain of Being after Fifty Years” in Journal of the History of Ideas 48.2: 187-206.

For text and concordance I have used the OpenSource Shakespeare (www.opensourceshakespeare.com), access 2010-03-21, always doublechecking with The Riverside Shakespeare (Ed. G. Blakemore Evans, Boston: Houghton Mifflin, 1974). 


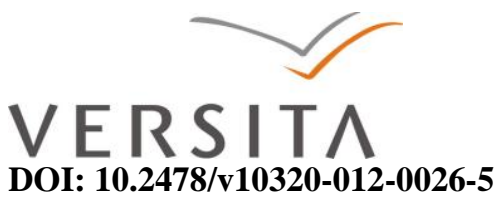

\title{
MARITIME FANTASIES AND GENDER SPACE IN THREE SHAKESPEAREAN COMEDIES
}

\author{
WAI FONG CHEANG \\ Chang Gung University, Taiwan \\ Wen-Hwa 1st Road, Kwei-Shan Tao-Yuan,Taiwan \\ cheangwf@mail.cgu.edu.tw
}

\begin{abstract}
Laden with sea images, Shakespeare's plays dramatise the maritime fantasies of his time. This paper discusses the representation of maritime elements in Twelfth Night, The Tempest and The Merchant of Venice by relating them to gender and space issues. It focuses on Shakespeare's creation of maritime space as space of liberty for his female characters.
\end{abstract}

Keywords: Shakespeare, maritime space, gender, Twelfth Night, The Tempest, The Merchant of Venice

As a crucial constituent of the planet Earth, the sea has always had some influence on socio-cultural aspects of human life, especially for islanders surrounded by water. Great works of world literature, such as Homer's Iliad and Odyssey, manifest human beings' deep involvement with the vast expanse of water around their lands. Not unlike the Greeks, the English, as islanders, have a long history of involvement with the sea. The English Renaissance was a period during which real and imaginary ambitions beyond seas boomed, stimulating rich literary productions reflecting this culturalhistorical reality.

The huge fantasies of the English regarding sea adventures during the Renaissance were triggered by excitement arising from the discovery of new lands and trade routes and the legends of successful pirates. "Chronicles of New World explorers," such as updated Jamestown narratives, "appeared regularly in London bookshops" and were read by "an eager public" (Woodward 2009:5-9). Water formed a part of the life of 
Londoners, as they constantly witnessed the arrival of ships loaded with foreign goods in the River Thames. The theatres were very closely involved with water, since crossing the river was needed for city-dwellers to attend the theatres, most of which were located in the Liberties on then other side of the Thames. As an English Renaissance playwright, William Shakespeare's fascination with the sea is apparent in many of his plays, such as Twelfth Night, The Tempest and The Merchant of Venice, which employ sea adventures as pivotal plot elements.

Renaissance maritime culture traditionally conceptualised the sea and sea-crossing vessels as male domains. Sea crossing for conquest and trade was often regarded as exclusively men's business. "The world of the seafarer," as Anne Chambers, Dian H. Murray and Julie Wheelwright write, "is both a world unfit for ladies and one where women's presence leads to disaster" (1995:11). Marcus Rediker, a student of eighteenthcentury Anglo-American maritime culture, points out that "seafaring was an occupation sharply segregated by sex" and that "women" did not ordinarily go to sea (1987:155). Margaret Lincoln also writes in her study of naval wives and mistresses in eighteenthcentury England that "seafaring is a predominantly male profession" (2007:16). If this was so even in the eighteenth century, women must surely have been excluded from seafaring in Renaissance England. During the Elizabethan era, the traditional concept of the sea as a male domain was reinforced by laws and sermons that contributed to a general culture of women's domestication.

Nevertheless, a certain degree of liberty or licentiousness could still exist for women within certain domains, such as theatrical space. There is a well-known funny story in H. Pecham's The Art of Living in London about a woman who went to the theatre after being warned about pickpockets by her husband but still lost her purse. When her husband inquired where she had put her purse, she told him that she had put it "under her petticoat, between that and her smocke." Then her husband asked whether she had felt anybody's hand under her dress. "Yes, quoth shee, I felt ones hand there; but I did not thinke hee had come for that" (1642:6). The story shows the licentiousness and liberty that existed in the Renaissance theatrical space and what a female theatregoer would expect from her trip. Yet "women from every section of society," as Andrew Gurr writes, "went to plays" (1987:67). 
In a certain sense, the world of the seafarer is rather similar to that of the theatre, as the seafarers have their adventures via the ship's "wooden world," (as Isaac Land calls it, 2009:16), while the players offer their audience imaginative adventures in their "wooden O." It is generally assumed that "players," as R. E. Pritchard writes, "needed to be beyond the reach of the City authorities" (2010:190). The outskirts of London, called the Liberties, which housed the theatres, were an "ambiguous realm," a "borderland", which was “'free' or 'at liberty' from manorial rule or obligation to the Crown, and only nominally under the jurisdiction of the lord mayor" (Mullaney 1988:21). It was a site where the city authorities could seem to be far away. There were calls for the brothels there to be closed, for instance, but the moves against these immoral institutions "always fell short" (Greenblatt 2004:176). Hence, just like the sailors' "wooden world," which could seem to be far from the jurisdiction of countries, the licentious Liberties of the players" "wooden O" could seem to be beyond the jurisdiction of the city fathers.

For female audiences who were in reality excluded from the seafaring business, plays about the thrilling dangers of sea adventures, and especially about female characters' involvement with sea -crossings, could be extremely appealing. Hence, the imagination of the sea as an open space full of opportunities not just for men but for women as well, as presented on stage, resembles the liberties for both men and women offered by the London theatrical space. In this licentious "wooden O," imagination could suspend the social reality that women were excluded from seafaring ventures. In the vicinity of brothels, dance halls, bear-baiting pits and scaffolds, playgoing could be an exciting and licentious event. And there was always a sense of adventure and danger involved, real or imaginary, as the cutpurse's hand under the female playgoer's dress suggests, that thrilled theatre goers.

The Tempest, which begins with "a tempestuous noise of thunder and lightning," as the stage direction indicates, vividly presents the imminent dangers of seafaring. Shakespeare has a ship-master, a boatswain and mariners trying to control their ship in a storm. Lines related to how to handle the ship, such as "Take in the topsail" and "Down with the topmast! Yare! Lower, lower! Bring her to try with main-course" (Tempest 1.1.6; 1.1.34-35), simulate the scenario of ship-steering. The sailors are so occupied that they do not answer Alonzo's question, even though he is the King of Naples. The 
boatswain simply asks the king to "keep below", and when Antonio again asks the boatswain where the master is, the boatswain replies, "You mar our labour: keep/ your cabins: you do assist the storm" (Tempest 1.1.11; 13-14). The boatswain even says, "What care these roarers/for the name of King? To cabin: silence! Trouble/us not" (Tempest 1.1.16-18). This initial scene shows not only the threatening power of the sea but also the professional dignity of sailors. The ship becomes a space where the usual power relationship between a king and his subject is subverted.

The sea as shown in the opening scene is undoubtedly an enemy to the men onboard. In a later scene, Francisco describes what happened to Ferdinand: "I saw him beat the surges under him,/And ride upon their backs; he trod the water,/Whose enmity he flung aside..." (Tempest 2.1.110-13). The word "enmity" highlights the relationship between the sea and those fighting for their lives against it. When Alonzo, Sebastian, Antonio, Gonzalo and others finally land on an island, Gonzalo encourages the others to be merry:

...our escape

Is much beyond our loss. Our hint of woe

Is common; every day, some sailor's wife,

The masters of some merchant, and the merchant,

Have just our theme of woe; but for the miracle,

I mean our preservation, few in millions

Can speak like us... (Tempest 2.1.1-7)

These words accentuate how common it is for the sea to take people's lives. Moreover, it also suggests that the sea is a male domain, as sailors' wives have their theme of woe, which implies that sailors are men. Sebastian also says after the shipwreck that "Milan and Naples have/mo widows in them of this business' making/Than we bring men to comfort them" (Tempest 2.1.128-30). By referring to the making of more widows in their thwarted sea-crossing business, Sebastian's words echo Gonzalo's in conceiving of the sea as a male domain. Moreover, the person who commands the tempest that sinks the ship is Prospero, a patriarchal figure. 
At the beginning of the play, when Prospero summons the tempest, Miranda expresses her disapproval. Sympathetic towards the sufferers on the ship, Miranda says to her father: "Had I been any god of power, I would/Have sunk the sea within the earth, or ere/It should the good ship so have swallow'd" (Tempest 1.2.10-13). Nevertheless, she possesses none of her father's power to command the sea. And though she says she desires to sink the sea within the earth, she is fascinated by what the sea brings forth to the island. She comments that the ship is "a brave vessel" (Tempest 1.2.6), and Ferdinand who lands on the island after the shipwreck, is "a thing divine; for nothing natural/I ever saw so noble" (Tempest 1.2.421-22). For Miranda, the malignant force of the sea in the form of the tempest may be dreadful but the benevolent force of the sea in bringing to her attractive elements from outside her small island is welcome. These conflicting features of the sea from Miranda's perspective can be considered as being a reflection of ordinary English people's ideas about the sea during the Renaissance. At a time when trade with foreign countries was becoming more and more frequent and the discovery of new lands and new trade routes was stimulating the development of more seafaring businesses, fear of sea-crossing dangers and fascination with new horizons inevitably coexisted.

Ariel's song for Ferdinand's ears, which begins "Full fadom five thy father lies" (Tempest 1.2. 399-404), echoes this kind of fear and fascination with the sea. Though the beautiful depiction of a sea death for Ferdinand's father is a hoax, the song reinforces the image of the sea as dangerous. "In symbolic terms" as Steve Mentz puts it, "the song represents the transforming powers of oceanic magic" (2009:7), a theme that is reinforced by Gonzola's comment about their garments which "hold, notwithstanding, their freshness/and glosses, being rather new-dyed than stained/with salt water" (Tempest 2.1.60-62).

The employment of a shipwreck as its basic plot frame renders Twelfth Night rather similar to The Tempest. Even though the play does not dramatise a shipwreck at the very beginning of the play, with mariners shouting instructions on how to handle the ship, in Act 1 Scene 2 it does dramatise the aftermath of a shipwreck, and it puts into the mouth of a sea captain a vivid description of how Sebastian struggled for his life after the ship split: "I saw your brother/Most provident in peril, bind himself/... To a strong mast that liv'd upon the sea" (Twelfth 1.2.11-14). In a later scene, Antonio, another sea 
captain, says he had rescued Sebastian "from the rude sea's enrag'd and foamy mouth" (Twelfth 5.1.76), thus personifying the sea and highlighting how dangerous it is. When Sebastian describes the shipwreck which he thinks has taken his sister's life, he also personifies the sea. He says his sister "the blind waves and surges have devour'd" (Twelfth 5.1.227). By poetically linking the salt water of the sea with his tears: "She is drown'd already, sir, with/salt water, though I seem to drown her remembrance/again with more (Twelfth 2.1.29-31), Sebastian presents not only the dangers of the sea but also the interconnection between human misery and the sea in the form of salt water.

Not unlike The Tempest, which endows the mariners with professional dignity, Twelfth Night depicts mariners in a favourable light. The captain who speaks with Viola after the shipwreck is a friendly character. His soothing words comfort Viola and the information he supplies about Illyria starts her on her bold venture. Viola compliments him: "There is a fair behaviour in thee, captain" and she adds that "I will believe thou hast a mind that suits/With this thy fair and outward character" (Twelfth 1.2.47; 50-51). When Viola asks him to conceal her identity and present her to the duke of Illyria as a eunuch, the captain readily promises to do so, in a heroic tone: "Be you his eunuch, and your mute I'll be:/When my tongue blabs, then let mine eyes not see" (Twelfth 1.2.62$63)$.

Likewise, Antonio befriends Sebastian and even lends him his purse with all his money. He is probably a wanted pirate, as he tells Sebastian that it is not without danger that he walks in town because he once served in a "sea-fight 'gainst the Count his galleys" (Twelfth 3.3.26). Moreover, when Orsino meets Antonio, he addresses him as "Notable pirate, thou salt-water thief" (Twelfth 5.1.67). But Antonio replies, "Be pleas'd that I shake off these names you give me:/Antonio never yet was thief, or pirate" (Twelfth 5.1.71-72). Interestingly, there is no further discussion about what exactly Antonio is, and this blank may be understood withinRenaissance maritime history. It is generally known that to empower the English in their conflict with Spanish sea power and expansion in the New World, Queen Elizabeth "let slip her sea dogs" (Konstam 2008:37). According to Augus Konstam, “one country's privateer is another country's pirate" (2008:37). This humorous description sheds light on why Antonio can defend himself boldly against Orsino's accusation. 
Pirate or not, Antonio shows his valour when he comes immediately to the rescue of Viola, who he has mistaken for Sebastian, when Viola is being attacked by Sir Andrew. He readily draws his sword and declares to Sir Andrew: "If this young gentleman/Have done offence, I take the fault on me;/If you offend him, I for him defy you" (Twelfth 3.4.319-321). In Antonio's own words, he has given Sebastian "[his] love, without retention or restraint,/All his in dedication" (Twelfth 5.1.79-80). Not unlike the favourable image of the mariners in the opening scene of The Tempest, Antonio's friendship and valour command respect. In making a captain, who is allegedly a pirate, command respect, Shakespeare probably has the topical issue of the Queen's sea dogs at the back of his mind.

A common denominator of The Tempest and Twelfth Night is the shipwreck that makes possible the coming-together of the main protagonists. Yet Twelfth Night swaps most of the gender roles of The Tempest. Instead of a hero who lands on the island after the tempest, Twelfth Night focuses on a heroine who survives a shipwreck. Viola becomes a counterpart of Ferdinand in their roles as new arrivals on the island, while Orsino becomes the counterpart of Miranda, as both are safe in their home but are powerless in their desires. In addition, the character who holds power on the island turns from Prospero, a patriarchal figure, to Olivia, a countess whose immediate male relatives have all died and who is hence left to command her own household. Though Orsino is the Duke of Illyria, he is not a patriarch like Prospero. The play begins by presenting Orsino's love-sickness.

This weakening of male power is strongly contrasted with the empowering of female characters. Olivia chooses to reject a suit from a most suitable candidate and instead follows her heart's desire in loving a man supposedly below her social rank; Viola chooses to disguise herself as a man to serve a duke whose story fascinates her. These wilful female characters seem to be rather different from the subservient female image one would usually expect of Renaissance women. Yet a close scrutiny of Miranda's part in The Tempest reveals her wilfulness as not greatly different from that of Olivia or Viola. After Ferdinand showers compliments on her, Miranda asks him straightforwardly: "Do you love me?" (Tempest 3.1.68). And she proposes to him: "I am your wife if you will marry me;/If not, I'll die your maid" (Tempest 3.1.83-84). This kind 
of forwardness is not greatly different from that of Olivia, who after she has mistaken Sebastian for Cesario and found him less resistant than before, summons a priest and arranges an immediate marriage. She tells Sebastian, who she thinks is Cesario: "If you mean well,/Now go with me, and with this holy man,/Into the chantry by" (Twelfth 4.3.22-24). In a rather similar fashion, Viola follows her own desires. When she is commissioned by Orsino to woo Olivia, she says to Orsino: "I'll do my best/To woo your lady" (Twelfth 1.4.39-40) but then she says in an aside, "yet, a barful strife!/Whoe'er I woo, myself would be his wife" (Twelfth 1.4.41-42).

Compared to the wilful female characters, the male characters in Twelfth Night are relatively powerless and innocent. Orsino never discovers that the young man close to him is in fact a cross-dressed woman, and Sebastian simply agrees to marry Olivia when she proposes, though he finds his good luck rather incredible. When Olivia says, "would thou'dst be rul'd by me," Sebastian replies, "Madame, I will” (Twelfth 4.2.63-64). These lines signify the reversal of gender roles from traditional male dominance to women on top. Even in the subplot that dramatises what is going on in Olivia's household, Maria, Olivia's waiting gentlewoman, is full of wit and tricks Malvolio, Olivia's steward, into believing that Olivia loves him. The prank provokes a good laugh at the expense of Malvolio, whose image resonates with the other powerless and innocent male images in the play.

Even though there is a real Illyria on earth, in the play this setting seems a dreamland. When Viola first arrives on the island and learns the name of the place from the captain, she says, "And what should I do in Illyria? My brother he is in Elysium" (Twelfth 2.1.3-4). Illyria's link (through alliteration) with Elysium gives the island a surrealistic touch. Moreover, with reversed gender roles on the island, Illyria resembles the island on which Prospero rules - a fictive land in a faraway place across the seas where the usual order and the usual relationships are reconfigured. What makes the protagonists' adventures possible is sea travel, and The Tempest and Twelfth Night share a shipwreck as their common denominator. The sea that causes the disastrous shipwreck at the beginning is eventually proven to be benevolent. As soon as Viola hears Sebastian's name on Antonio's lips, she begins to suspect that he is still alive and says: "O if it prove,/Tempests are kind, and salt waves fresh in love" (Twelfth 3.4.393-394). 
The dangers of seafaring are also crucial to the development of the plot in The Merchant of Venice. Even though there is no actual staging of shipwrecks, Shylock offers a picture of how vulnerable ships can be on the sea:

\author{
But ships are \\ but boards, sailors but men, there be land-rats, and \\ water-rats, water-thieves, and land-thieves, (I mean \\ pirates), and then there is the peril of waters, winds, \\ and rocks. (Merchant 1.3.19)
}

What eventually happens in the play proves that Shylock is quite correct. The failure of Antonio's ships to return creates a violation of the bond that makes Shylock demand a pound of Antonio's flesh, as stated in their agreement. It is noteworthy that when Shylock proposes the uncivil terms of having Antonio agree to pay a pound of flesh as eventual penalty, Antonio readily agrees, though Bassanio tries to stop him. Antonio says "Why fear not man, I will not forfeit it" (Merchant 1.3.152). Antonio's complacency is eventually proved to have been foolish.

The Merchant of Venice opens with a discussion of the mental burdens of seafaring for merchants. Antonio is sad but says he does not know why he is so sad, to which Salerio replies: "Your mind is tossing on the ocean" where your "argosies" are sailing (Merchant 1.1.7-8). Solanio says,

Believe me sir, had I such venture forth,

The better part of my affections would

Be with my hopes aboard. I should be still

Plucking the grass to know where sits the wind,

Piring in maps for ports, and piers and roads:

And every object that might make me fear

Misfortune to my ventures, out of doubt

Would make me sad. (Merchant 1.1.15-22)

Salerio adds: "My wind cooling my broth,/Would blow me to an ague when I thought/What harm a wind too great might do at sea" (Merchant 1.1.22-24). He 
elaborates further on how an hour-glass would prompt him to imagine that his ship was docked in sand, and how the stones of a church would make him relate to the "dangerous rocks" in the sea. This vivid description of the mental burdens of a merchant with ships at sea illustratess the risks involved in seafaring. But Antonio denies having such worries and says, "My ventures are not in one bottom trusted,/Nor to one place; nor is my whole estate/Upon the fortune of this present year" (Merchant 1.1.42-44). But what he says at this point is not the whole truth, because when Bassanio approaches him to borrow money, Antonio says, "Thou know'st that all my fortunes are at sea" (Merchant 1.2.177). These words contradict his earlier comment that his whole estate does not depend upon the fortune of that year. And then what happens next is Antonio staking his own life on the risky ventures of his ships. He says to the worried Bassanio, after he has agreed to go to the notary's with Shylock to seal the bond, "Come on, in this there can be no dismay,/My ships come home a month before the day" (Merchant 1.3.176-77).

When compared to Solanio and Salerio's description of their excessive worries about their ships, Antonio's confidence about the return of his ones is naive. The perils of seafaring in the Renaissance, in the absence of modern nautical equipment, far exceeded those of our own era. Reports of misfortunes at sea were common in Shakespeare's time. William Strachey's A True Reportory of the Wreck and Redemption of Sir Thomas Gates, Knight, upon and from the Islands of the Bermudas: His Coming to Virginia and the Estate of that Colony Then and After, under the Government of the Lord La Warr, July 15,1610 is a good example. "[Strachey's] account of a shipwreck on an enchanted isle," according to Hobson Woodward, was the inspiration for The Tempest (2009:182). Since it is generally believed that Strachey's work inspired Shakespeare's The Tempest, it is reasonable to think that reports of this kind also contextualised The Merchant of Venice. Therefore, even though Antonio may think that the penalty Shylock is proposing is "overwhelmingly likely to remain uncollected" (to borrow Spencer's words 1988:102), Bassanio's concernis more realistic than imaginative, and Shakespeare has already created the atmosphere for such a worry early in the play by including Solanio and Salerio's description of merchants' mental burdens for their ships. Moreover, by choosing Salerio as Antonio's messenger to Portia's home, the play reminds us of what Salerio had said at the beginning of the action about the dangers of seafaring. 
Nevertheless, the sad news from Salerio is later proven to be incorrect. Near the end of the play, Portia gives Antonio a letter and tells him the good news contained within it: "There you should find three of your argosies/are richly come to harbour suddenly" (Merchant 5.1.276). This late information of the recovery of three of Antonio's ships reminds one of how unpredictable and unmanageable the seafaring business is. How Portia has acquired the information and the letter remains unknown, as she states that "You shall not know by what strange accident/I chanced on this letter" (Merchant 5.1.279-30). John Russel Brown's annotation comments that "this beautiful example of Shakespeare's dramatic impudence has been severely criticized by some pundits" (1964:138). Yet the fact that it is Portia who has this information adds a magical touch to her role. Earlier in the play, when she cross-dresses to help Antonio out, she has already manifested her good logic. The joke she plays with Bassanio's ring is rather similar to the tricks Prospero plays via Ariel to those shipwrecked. In a sense, Portia's knowledge and wit make her almost a female counterpart of Prospero. Even though she does not have any power to command a tempest, she has information about ships which even their owners have lost track of. Yet she differs from Prospero in her heartfelt forgiveness for her husband after he has given away the ring she had given to him as a love token. According to Auden, Prospero "has the coldness of someone who has come to the conclusion that human nature is not worth much" (2003:57), but in Portia no such coldness exists. While Prospero's magic to command the tempest may signify man's wish to dominate the sea, Portia's unexplained information about Antonio's ships symbolises a mysterious relationship between woman and the sea.

The quintessential plot element in The Tempest, Twelfth Night and The Merchant of Venice is the danger of seafaring. In Twelfth Night and The Merchant of Venice, the female characters cross-dress for reasons related to a shipwreck. Even in The Tempest, where a patriarchal figure like Prospero holds royal power, Miranda benefits from what the sea brings to her. One of the most interesting things about women's relationship with the sea in The Tempest is that the journey which takes the king's company onboard a ship is for the king's daughter, Claribel. This absentee from the play, who marries the king of Tunis, is the cause of the sea-crossing from Italy which gives an opportunity for Prospero to sink the ship. After the shipwreck, the king laments, 
Would I had never

Married my daughter there! For, coming thence

My son is lost, and, in my rate, she too,

Who is so far from Italy removed

I ne'er again shall see her. (Tempest 2.1.103-107)

The king's words reveal that distance across seas creates great obstacles to the meeting of people who live far away from each other. In The Tempest, when Antonio is encouraging Sebastian to usurp his brother's crown, he says that the next heir of Naples after Ferdinand is Claribel, Queen of Tunis, but she is not to be feared because: "she that dwells/Ten leagues beyond man's life; she that from Naples/Can have no note" (Tempest 2.1.241-43). Again, this shows the barriers the sea can create between the rightful queen and her inheritance. Though the reason why Claribel marries the ruler of a faraway country across the seas is not mentioned in the play, the marriage stimulates imagination about her adventure. Moreover, it is this absentee who initiates the trip that is crucial to the plot. So after all, Claribel's marriage overseas in The Tempest signifies a new possibility for women.

To conclude, even though in the Renaissance the sea was a male domain, Shakespeare would not allow the enormous fantasies of the English during his time regarding sea adventures to exclude women in his theatrical space. Within the imaginative space of Shakespeare's "wooden O," maritime space is dramatised as a space of liberty and opportunity for women. This aspect may have appealed powerfully to his female audience because whereas in reality they found themselves excluded from an extremely fascinating element of their own culture, they could find their comfort from the wild imagination of theatrical space. This wild imagination also harps on a "supreme irony" of the time, which, to borrow Carol Hansen's words, is that "a woman, Elizabeth I, was running the whole show, or to be more precise, the whole country" (1993:4). She was the one who commanded the navy and the privateers, her sea dogs. Not unlike Portia in The Merchant of Venice, who knows about the fate of Antonio's ships, Queen Elizabeth commanded information about ships at sea. Not unlike Claribel, who was the 
reason for the king's sea-crossing in The Tempest, Queen Elizabeth commanded many activities on the sea, including her most famous triumph, that over the Spanish Armada.

It is notable that Queen Elizabeth's great triumph over the Spanish Armada was the result of "a great tempest” (Kay 1992:104). Shakespeare's career as a dramatist began, "in the years immediately following the defeat of the Spanish Armada" (Kay 1992:104). It is hence reasonable to believe that Shakespeare would remember the significance of the tempest in his Queen's glorious triumph over the Spanish. Though in The Tempest Shakespeare creates a male character who commands the tempest, it is rather interesting to link the positive outcome of the tempest for Miranda with what the tempest meant to Queen Elizabeth in the war against the Spanish Armada. The imaginative world of Shakespeare's theatrical space reflects the historical reality of his time - the tempest has impacts not just on men on board ships, but on women too. Yet there is a great difference between Shakespeare's imaginative world and historical reality when it comes to the marriage issue. In the three comedies related to seafaring, the female characters end up with good men to marry, while Queen Elizabeth did not.

It is well known that Queen Elizabeth carried on many marriage negotiations but never married. Many reports of Elizabeth's actions, as Ilona Bell comments, “disturbed conceptions of sex and gender and challenged the patriarchal assumptions underlying politics and marriage" (2010:xii). The attack of the Spanish Armada could even be considered the result of Queen Elizabeth's failed marriage negotiations with King Philip of Spain, as he was her first 'husband candidate' when she became queen but she refused his marriage proposal. According to William Camden, when the Spanish Armada withdrew from the English seas in 1588, "the Queen with a masculine Spirit came and took a View of her Army and Camp at Tilbury," and she rode about "sometimes with a martial Pace, another while gently like a Woman" (1970: 326). The description pinpoints the Queen's embodiment of both masculine and feminine traits. It is perhaps presumptuous to argue that Shakespeare has the self-styled virgin Queen in mind when he wrote these comedies about women crossing the seas and cross-dressing for love and for marriage, but it is undoubtedly interesting to forge the imaginative link.

\section{References}


Auden, W. H. 2003. The Sea and the Mirror: A Commentary on Shakespeare's The Tempest.” Ed. Arthur Kirsch. Princeton: Princeton University Press.

Bell, I. 2010. Elizabeth I: The Voice of a Monarch. New York: Palgrave Macmillan.

Camden, W. 1970. The History of the Most Renowned and Victorious Princess Elizabeth Late Queen of England: Selected Chapters. Ed. W. T. MacCaffrey. Chicago: University of Chicago Press.

Chambers, A., D. H. Murray, and J. Wheelwright. 1995. Bold in Her Breeches: Women Pirates Across the Ages. Ed. J. Stanley. San Fransisco: Harper Collins.

Greenblatt, S. 2004. Will in the World: How Shakespeare Became Shakespeare. New York: W. W. Norton.

Gurr, A. 1987. Playgoing in Shakespeare's London. $3^{\text {rd }}$ ed. Cambridge: Cambridge University Press.

Hansen, C. 1993. Woman as Individual in English Renaissance Drama: A Defiance of the Masculine Code. New York: Peter Lang.

Kay, D. 1992. Shakespeare: His Life, Work and Era. New York: William Morrow.

Konstam, A. 2008. Piracy: The Complete History. Oxford: Osprey.

Land, I. 2009. War, Nationalism and the British Sailor, 1750-1850. New York: Palgrave Macmillan.

Lincoln, M. 2007. Naval Wives and Mistresses. London: National Maritime Museum.

Mentz, S. 2009. At the Bottom of Shakespeare's Ocean. London: Continuum.

Mullaney, S. 1988. The Place of the Stage: License, Play, and Power in Renaissance England. Chicago: University of Chicago Press.

Pecham, H. 1642. The Art of Living in London, or, A Caution How Gentlemen, Countreymen and Strangers Drawn by Occasion of Businesse Should Dispose of Themselves in the Thriftiest Way, not Onely in the Citie, but in All Other Populous Places. As also, a Direction to the Poorer Sort that Come Thither to Seeke Their Fortunes. London: Printed for John Gyles, and are to be sold by Samuel Rand, at his shop at Barnards Inne in Holborne.

Pritchard, R. E. 2010. Shakespeare's England: Life in Elizabethan and Jacobean Times. Thrupp, Stroud: Sutton.

Rediker, M. 1987. Between the Devil and the Deep Blue Sea: Merchant Seamen, Pirates, and the Anglo-American Maritime World, 1700-1750. Cambridge:

Cambridge University Press.

Shakespeare, W. 1964. The Merchant of Venice. Ed. J. Russel Brown. The Arden

Shakespeare ed. London: Methuen.

---. 1964. The Tempest. Ed. F. Kermode. The Arden Shakespeare ed. London: Methuen.

--- 1975. Twelfth Night. Ed. J. M. Lothian and T. W. Craik. The Arden Shakespeare ed. 
London: Methuen.

Spencer, C. 1988. The Genesis of Shakespeare's Merchant of Venice. Lewiston, New York: Edwin Mellen.

Woodward, H. 2009. A Brave Vessel: The True Tale of the Castaways Who Rescued Jamestown. London: Penguin. 


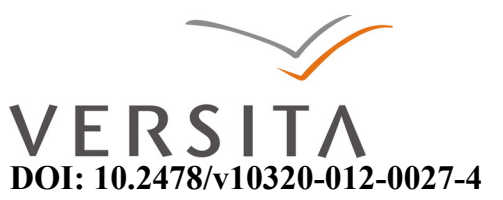

\title{
PATTERNS AND REPRESENTATIONS OF SHAKESPEAREAN LOVE: HUBRIS, INFATUATION, AGAPE IN HAMLET
}

\author{
BIANCA FOGHEL
}

West University, Timişoara,

4, Pârvan Blvd, Timișoara, Romania

foghelbianca@gmail.com

\begin{abstract}
The more conceptually elusive love has proven to be, the more it has whetted humanity's appetite to try to narrow it down. Could one say that Shakespeare is one of the few personalities that managed not only to exemplify almost all recurrent patterns of love, but also to recreate them, in his case, within his plays? Is love weak, or is it so strong that it gives life to a character, only to overwhelm and destroy him/her later? Are there any archetypal emotional stages, or is it a fiery combustion? These are all questions which this paper will attempt to discuss with regard to Hamlet.
\end{abstract}

Keywords: Agape, gender stereotypes, Hubris, love dynamics, women between virtue and evil

Shakespeare's genius has proven to be a source of endless discussions, critical publications and stage representations that have clearly placed him at the head of any list of playwrights, not only in England, but in the whole world. The celebrated figure Shakespeare has become has much to do with the celebrated individuals in his plays.

The present work deals with what is generally accepted as one of Shakespeare's most famous plays, without paying special attention to chronology or other structurerelated issues, but focusing much more on matters of emotional interest in Shakespearean drama, the coexistence of the two genders, its evolution or involution, whether it is constructive or destructive. Alongside these major divisions, I have begun the paper with a brief introduction to the concept of love, as this is the starting point and the favourable environment for the development of inter-gender relationships. 
As mentioned earlier, this analysis focuses on the problematic issue of love, which has at times a very abstract meaning, a meaning that medieval or Renaissance philosophers tried to reshape into a more palpable concept, even though they could never attain the incontestable complexity and depth of Shakespeare, one of the most celebrated figures of the Elizabethan age. It is clear that the patterns revolving around love are construed according to other, broader paradigms, such as that of the social and historical context that to a great extent shape gender dynamics. The deviations that may occur at any paradigmatic level are due to more subtle social co-ordinates such as epistemology, ethics and metaphysics. However, Hamlet's solitary self is set against social custom, which makes him a very early instance of Modernism. Modern interpretations of the play propose strong psychological motivation for him and Freud has taught us much about such contradictory states of mind (since Hamlet both asserts and denies his love for Ophelia), but in part he is responding to Renaissance stereotypes of women. Eve or the Virgin Mary: women were seen either as extremely flawed or as paragons of virtue. Since few real women approach perfection, they are seen as evil, especially vulnerable to the Devil and his wiles, situated between the virginal ingénue and the villainous temptress, but always at an extreme. Ophelia must therefore head for the nunnery, or she will inevitably be corrupted and Gertrude has already fallen:

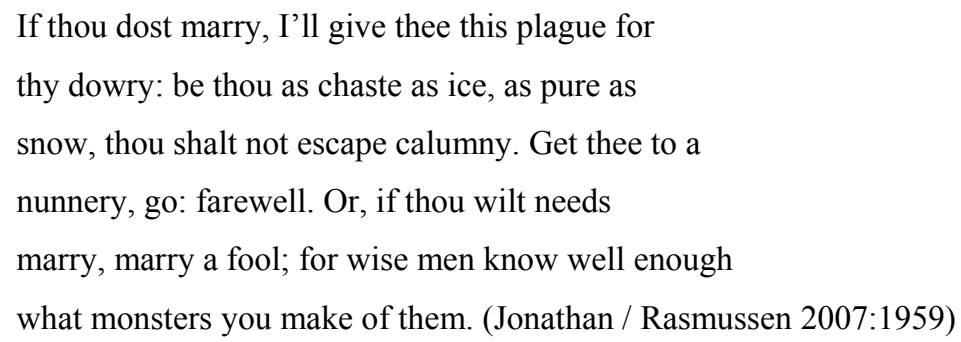

"Women in early modern England, as elsewhere in Europe, benefited from a limited range of scripts as specific contexts in which they lived or as descriptors of their status or character. [...] Female categories were either domestic, with a moral connotation - virgin, wife, mother - or antisocial - scold, whore, witch" (Percec 2006:190). 
During the Middle Ages, the Church was the decisive pillar for most societies; thus, however paradoxically, affective freedom was "dictated" by restrictions and theories that did not always have a positive effect upon people's morale. Sexuality was not seen as an implicit part of a marital relationship, but rather as an act devoid of pleasure and clearly oriented towards leaving heirs and closing a financial deal between the two families involved. By the end of the $11^{\text {th }}$ century, the church was the exclusive owner of marriage.

During the Renaissance, philosophers such as Marsilio Ficino (1433-1499) developed highly elaborate theories relating the idea of love to psychological concepts, much closer in meaning to the contemporary perception of the notion. For that period, Ficino's perspective, which sees love as a game of knowledge as well as an unconscious overlapping of our inner self and the external image of the loved one, brings fineness to the concept, breaking with tradition and setting it on a much higher level in the hierarchy of values. The Renaissance period focuses on the singularity of the individual and so does Ficino. Men and women are equally entitled to express themselves through art, feeling and emotion. The patriarchal society of the Middle Ages was no longer as common in the Renaissance, since this era took both genders into account, feminine beauty and sexuality being as inspiring as masculine. In this context, where order is constantly asserted, the fact that it is a woman who is seen as

\footnotetext{
the cause of the excess and deficiency in the play [...] takes on further resonance, seeming to echo another fundamental drama of psychic experience as described by Freud. This is the drama of sexual difference where the woman appears as the cause of just such a failure in representation, as something deficient, lacking or threatening to the systems and identities which are the precondition not only of integrated artistic form but also of so-called normal adult psychic and sexual life (Rose 1985:96).
}

This is how the idea of the destructive power of love upon the human soul is introduced. Hamlet experiences this collapse, runs it through the filter of his mind, articulates it through his ambiguous language, but is unable to figure out strategies for solving it, because the troubled relationships between men and women are the consequence of a constant interpretation, misinterpretation and reinterpretation of each 
other's feelings and their reliability. The various meanings of words build a linguistic maze, just like the emotional maze built by gender discrepancies, where the Shakespearean heroes lose their way, and hence the opposition between the signified and the signifier, thus the irreversibility of the situation, the final collapse and the hope that the irreversible will become reversible, at least at a spiritual level. It seems that these Shakespearean psychological patterns have continued to reverberate up to the present day, without having lost their applicability to human nature.

The patterns of love in particular are extremely complex and intricate, display enormous powers of representation. Their timelessness is certainly due to their accuracy and psychological reliability: traits and behavioural propensities, even though often deviant, never seem unnatural or without motivation. The reader or the spectator comes to relate to the characters in such a profound way that she/he senses the motivational triggers behind each histrionic act or discourse.

In the case of Hamlet, Ficino has given us the theory of the pathological consequences of love that underlines the essence of the play, the state of mind of the protagonist and the influence of love upon him. Hamlet's constant melancholy is not only the result of the evil eye, his love for Ophelia, but also a consequence of the loss of his ability to love, thus his disgust for femininity and sexuality and his desire for vengeance. Melancholy, hubris and the associated loss of contact with reality take over Hamlet, forcing him to remain on the path of vengeance throughout the play and to experience all its symptoms, namely anomalous behaviour, emotional instability, and an inevitable and gradual loss of sanity. He expects perfection from the other, as he presumably believes himself to be capable of delivering it; Ophelia in particular is burdened with such an expectation of perfection, and Hamlet associates her physical beauty with lecherousness:

\footnotetext{
That if you be honest and fair, your honesty should admit no discourse to your beauty. (Jonathan / Rasmussen 2007:1958)
}

Hamlet experiences his greatest peril when he feels betrayed by Ophelia's love and he himself becomes unable to love and falls into the trap of unfathomable hubris, allowing his idealistic urge for vengeance to take over his entire soul, casting aside any possibility of achieving agape, the only redeeming form of love. Agape, the Greek term 
for pure, spiritual love, is meant to designate the supreme feeling, fiery and serene at the same time, but always authentic. It represents pure Eros, the ascension of the soul towards the supreme union, "beyond all forms of love that are possible in a human's life, therefore a type of love that has nothing to do with marriage" (Percec 2006:235). Ophelia tells of how she witnessed Hamlet uttering a sigh that seemed to "end his being". An end that could also have been considered a beginning: the birth of a new man dedicated to the proposition that the opposite of reason is not madness, but true feeling. However, the clear-mindedness necessary for attaining agape and overcoming his ego eventually eludes him because of his irresolution and inaction. He knows that authenticity of feeling is paramount, but since everything around him seems to reek of betrayal, he cannot devote his extreme self-consciousness to moulding his character powerfully enough. Owing to his highly developed intellectual powers - and his broad and many-sided sympathies, Hamlet can never take a simple view of any question - but always sees a number of different aspects and possible explanations for every problem. A given course of action has never seemed to him unequivocal and obvious, so that in practical life his scepticism and reflective powers have paralysed his conduct. He thus stands for what may roughly be called the type of an intellect over-developed at the expense of the will, held up as a warning example of losing oneself in abstract trains of thought at the expense of contact with reality. He does not even accept that someone else can feel a sorrow as poignant as that he himself experiences; when Laertes bewails the premature death of his sister, Hamlet swiftly intervenes:

What is he whose grief

Bears such an emphasis? whose phrase of sorrow

Conjures the wandering stars, and makes them stand

Like wonder-wounded hearers? This is I,

Hamlet the Dane. (Jonathan / Rasmussen 2007:1990)

And in the same passage he reasserts his love, a love that has undergone too many extreme stages of metamorphosis, from utter abandonment, to denial, rejection and reacceptance: 
I loved Ophelia: forty thousand brothers

Could not, with all their quantity of love,

Make up my sum. What wilt thou do for her? (Jonathan / Rasmussen 2007:1991)

Misogyny, another pattern in gender dynamics, becomes omnipresent in his relationship with women, Ophelia now being constantly rejected, treated with arrogance, insulted and disrespected, while Gertrude is denied as a mother-figure and seen as an incestuous being who is unworthy of his filial affection. Since for the common societal frame sexuality entails danger and “violates property, Gertrude's impropriety ('her 'o'erhasty' marriage') [...] provokes a crisis which overturns the sexual identity of the central male character of the drama. Hamlet, in response to his mother's 'flagrancy', projects the same flagrancy onto the image of the innocent Ophelia" (Rose 1985:97). For Hamlet, Gertrude's blatant sexuality makes her less than human, lacking "discourse of reason" (III. ii. 150), being the victim of infatuation and lust for power.

Therefore, Ophelia is the person that suffers longer-term, since her conflict with Hamlet is not her only problem, her father's death being another reason for her grief. The death of the loved person is the only possible end to the path of vengeance. The prince does not stop until he has destroyed Ophelia, since all he can perceive now in the essence of femininity is the lack of this essence, namely "nothingness". It is as if Hamlet had eradicated a feeling that was potentially going to evolve from sheer infatuation to a pure and requited love. He disrupts with his spite the naturalness of a gradually growing intensity, and everything in his perception converges around the void that remains after Ophelia's love is thrust aside, which he naively hopes to fill again by avenging his father. The love-vengeance association is an archetypal one, and as history and literature have taught us, this is not the first time that the latter has prevailed, stirred by inherent hubris. It seems that the love between Hamlet and Ophelia was a mere combustion that once ablaze burned itself to ashes. Polonius warns Ophelia about the transience of mere infatuation:

When the blood burns, how prodigal the soul

the tongue vows: these blazes, daughter,

Giving more light than heat, extinct in both, 
Even in their promise, as it is a-making,

You must not take for fire. (Jonathan / Rasmussen 2007:1978)

The two women, Gertrude and Ophelia, are equally important for Hamlet's existence, but they differ and are actually opposites in terms of their personalities: one is weak and transparent, while the other is powerful. They both end up dying for the protagonist's sake, for his understanding of the true meaning of things, for the ending of all his questions and dilemmas. However, is Hamlet really in love with Ophelia? And conversely, does Ophelia ever say or do anything to indicate she loves Hamlet or is it all a matter of egocentric infatuation?

Hamlet tells the story from the standpoint of the void itself. The mysterious opacity, the central recalcitrance which baffles and resists interpretation, is none other than woman and desire. In Hamlet that opacity, while closely related to female sexuality, is quite evidently the protagonist himself, whose enigmatic nature is legendary in world literature. The particular form of negativity which Hamlet experiences is melancholia, augmented by hubris which, rather like paranoid jealousy, drains the world of value and dissolves it into nauseating nothingness:

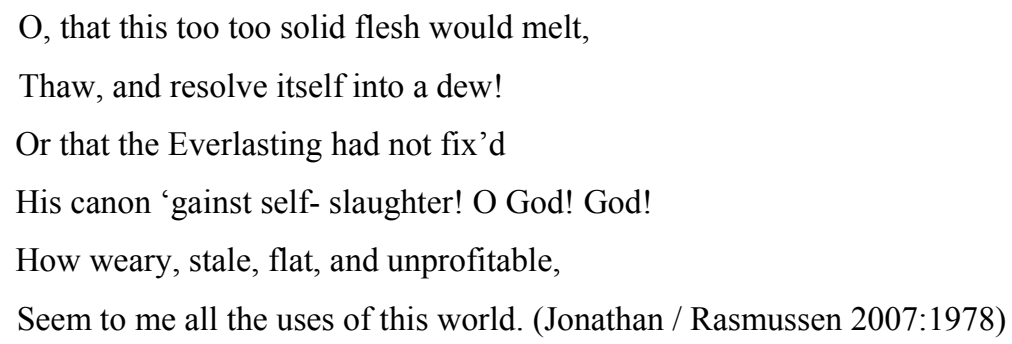

What Hamlet has importantly lost appears to be less his father than his mother, who has committed at least two grievous errors: she has revealed herself capable of desire, a scandalous thing in a woman, let alone in a mother, and that desire is not for Hamlet himself, but for another man. Once the imaginary relation between Hamlet and Gertrude has been ruptured by the entry of Claudius, Hamlet teeters hesitantly on the brink of the symbolic order (the system of allotted sexual and social roles in society), unable and unwilling to take up a determinate position within it. Indeed he spends most of his time eluding whatever social and sexual positions society offers him, whether as 
chivalric lover, obedient avenger or future king. This inner being, as he coldly informs Gertrude, evades the mask of the signifier:

Tis not alone my inky cloak, good mother,

Nor customary suits of solemn black,

Nor windy suspiration of forc'd breath,

No, nor the fruitful river in the eye,

Nor the dejected haviour of the visage,

Together with all forms, moods, shapes of grief,

That can denote me truly. These, indeed, seem;

For they are actions that a man might play;

But I have that within which passes show -

These but the trappings and the suits of woe. (I .ii.77-86)

Hamlet's reluctance or inability to re-enter the symbolic order, and his revulsion from the sexuality which reproduces it, are in one sense regressive states of being. His Oedipal attachment to his mother fragments his being, since it swerves round all determinate objects (Ophelia, filial duty, political power) that cannot be represented other as a lack. But this psychological regression is also, paradoxically, a kind of social progressiveness. Hamlet is a radically transitional figure, stretched out between a traditional social order to which he is marginal, and a future epoch of achieved bourgeois individualism which will succeed it. Because of this we can glimpse in him a negative critique of the forms of subjectivity typical of both these regimes. It is his regressiveness which makes him so modern: eccentric to the traditional order but still oppressed by it, unable to transgress its definitive limits into a fully alternative style of being. This is why many commentators have discerned something peculiarly "modernist" in Hamlet, apart from being one of the earliest representations of the Freudian Oedipal complex and its somewhat extreme manifestations. The French critic Henri Fluchère, who sees Hamlet as "the first Shakespearean drama which can lay claim to both extremes in personality and universality", interprets the play as a symbolic representation of the battle between man and his destiny, his temptations and contradictions. (Johnson, A Lecture on Shakespeare's Hamlet). 
The character of Hamlet could easily be placed in a distant sphere of the incomprehensible and the unknown, since to understand Hamlet is to reflect on the constitution of the human mind. Being a victim of mere meditation, Hamlet has lost his capacity, his natural power of action, thus becoming the drama of a man who does not hesitate to confront his own imperfections and who refuses illusions and idealistic appearances:

What piece of work is a man, how noble in reason, how infinite in faculties, in form and moving how express and admirable, in action how like an angel, in apprehension how like a god: the beauty of the world, the paragon of animals - and yet, to me, what is this quintessence of dust? Man delights not me [...] (Jonathan / Rasmussen 2007:1970)

- Hamlet's response to his friends, Rosencrantz and Guildenstern, when he realises that they are acting on the King's behalf. Hamlet associates the human immanent imperfection of character with that of love, thus rejecting this only redeeming feeling. The tragedy, Fluchère tells us (Johnson, Lecture on Hamlet), takes place above all in Hamlet's consciousness, as all the events which form the play's framework are reduced to a symbolic representation, to an internal unrest which no action will resolve and no decision will quell. The deepest theme, masked by that of vengeance, is none other than human nature itself, confronted by the metaphysical and moral problems moulded by love, time, death, perhaps even the principle of identity and quality, not to say being and nothingness.

The troubles encountered by the young Prince are not only the result of his discovering the murder of his father and the incest committed by his mother and uncle, but also stem from his idealism that causes him to link the whole of humanity to the flaws of those around him. Throughout the play, Hamlet teaches the audience the depths of his depression through soliloquies that convey a very embittered and cynical outlook on life. The foremost cause for his exasperation is repulsion towards his mother's actions, as he cries out - "Frailty, thy name is woman". The Prince develops a burning hatred that goes beyond his mother and extends to women in general. It is this furious mindset that is responsible for his terrible treatment of sweet, innocent Ophelia in Act III. 
However, it is not always like that. Hamlet is theoretically very much in love with Ophelia up to that particular point. The only problem is that we do not see that stage of their relationship, "the very ecstasy of love"; we see neither Hamlet as a lover, nor Ophelia expressing her affection for the Prince of Denmark, because the days when he supposedly expressed his love were before the opening of the drama, before his father's spirit revisited the earth. We only see him as drowning in a sea of trouble, of perplexities, of agonies, of terror. It is as if the reader or the spectator is presented with the ashes of a love prematurely buried in the ground of human flaws.

It has been stated that "in the case of love, the object's image is corrected at the innermost level because of the subject's desire to harmonize it with their most secret aspirations" (Percec 2006:227). What is somewhat sinister is that Hamlet's idealism paradoxically exhibits nihilistic hues, since although powerful enough to create almost palpable associations in his mind it is blinded by hubris and thus lacks the power to redeem Ophelia in his eyes. He admits to Ophelia:

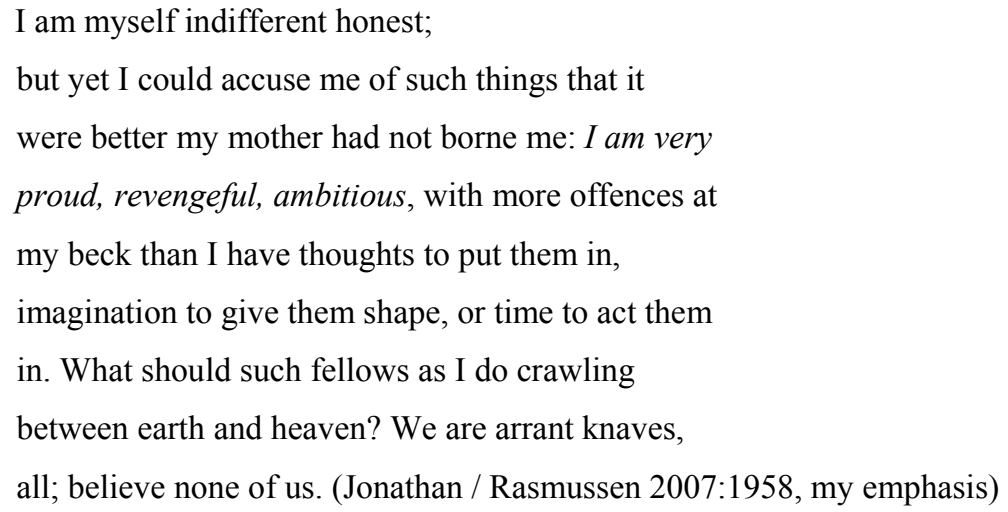

This excessively idealistic ambition might actually be a representation of the Greek term hamartia, a term more properly understood as an error in action rather than as a fatal weakness of character. To think of the tragic hero as afflicted with a 'fatal flaw' is to simplify and misunderstand the complex problem of the tragic protagonist and the society with which he or she is in conflict. "Defining the tragic hero mainly in terms of a flaw makes it too easy for us to pigeonhole the experience of a complicated character and thus insulates us from complicity in that character's responsibility or guilt." (McDonald 1996:169). Hamlet is frequently described as flawed by an inability to make up his mind, 
but the Prince of Denmark is a staunch seeker after truth, a subtle thinker who wants to know the facts and then to act rightly on the basis of what he knows. The play represents the collision between the hero's admirable aim and the traps and obstacles that the world places in his way. Hamlet's hesitation may derive from a "laudable moral repugnance at undertaking the role of the avenging son. [...] But his idealism carries a tragically high price - the death of Polonius, the suffering and suicide of Ophelia, and the entrapment of the hero in the very world he has set out to oppose" (McDonald 1996:170).

During the Middle Ages and subsequently, in the Renaissance period, many questions were asked regarding the human being. On the one hand, the focus of these questions were men and Giovanni Pico della Mirandola considered that when God said man was free to decide for himself about the way in which he wished to live, He was referring to Adam only. Women were considered filthy and were associated with sexuality and sin by the Fathers of the Church, who thought Eve was to be blamed for the original sin. Men who longed for atonement had to stay away from women and women had to stay away from themselves (Verdon 2009:50). Tertullian answers the question "What is a woman?" by listing a long series of vices (the enemy of friendship, a necessary evil, the essence of evil, the primal temptation).

It was very frequent at that time to make a Manichean distinction between the sexes: active-passive, soul-body, good-evil, valuable-useless, and although this distinction was diminished, for Aristotle, woman was considered an error of nature, while for Thomas Aquinas she was "an imperfect man" (Verdon 2009:51). Both Thomas Aquinas and Aristotle thought woman played a very important part in the house, always depending on male authority; the fact that women were indispensable did not mean they were equal.

However, in Shakespeare's dramas women play an important role. Love is a matter that brings about conflicts and interior tensions, but it is definitely needed in order to show the humane side of the characters in general and the protagonist in particular. Hamlet falls in love with the beautiful Ophelia despite the fact that this unleashes a battle between sexes, between Hamlet's highly rational life and Ophelia's instincts, between his philosophical judgment and her romantic vision. 
Ophelia is generally considered the victim of the play. She is a victim of her own weaknesses first of all, a victim of Hamlet, of Gertrude, of her father Polonius and even of King Claudius - Claudius' killing of Hamlet's father brings about Hamlet's scheme to make people think he is mad which brings about the death of Polonius, which leads to Ophelia's death. Her death also raises questions - was it an accident or a suicide?

She is a rather static, one-dimensional character; she is manipulated by most of the people she cares for and although she has the potential to become a tragic heroine, she does not manage to overcome fear and instead crumbles into insanity, becoming merely tragic. Like King Lear, Ophelia finds that in madness she can think and say things that would be impossible in the sanity of a supposedly ordered society. Does she use the language of flowers to attack Gertrude and Claudius? Ophelia's madness, brought on by her frustrated love and the bizarre way her father was killed by her loved one, seems less ambiguous than Hamlet's for her language and behaviour are clearly irrational. Gertrude is, more so than any other character in the play, the antithesis of her son, Hamlet. Hamlet is a scholar and a philosopher, searching for life's most elusive answers. He cares nothing for this "mortal coil" and the vices to which man has become slave.

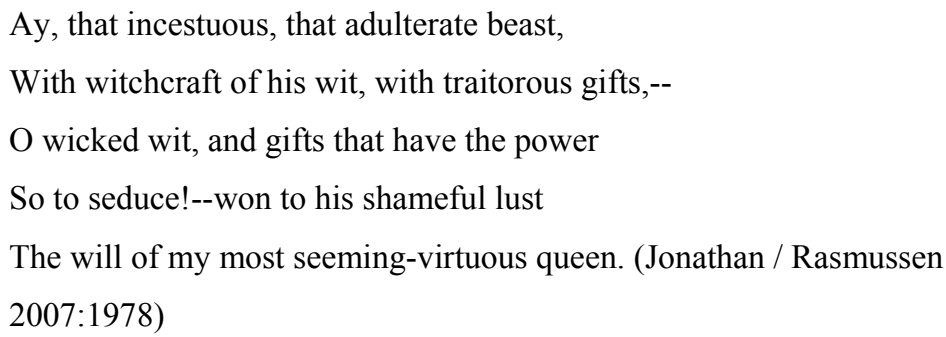

The philosophy of Shakespeare's plays is a careful observation and meditation upon human beings, life and a kaleidoscope of human relations, "by the assimilation of the ancient wisdom; morals is conveyed either in laughter or in the moments of solemn resignation, hesitation or despair. Shakespeare wrote for people's most secret tastes for comedy and tragedy, man's ascent and decline" (Olaru 1976:398). And "the rest is silence".

\section{References}


Bate, J. and E. Rasmussen. 2007. William Shakespeare. Complete Works. Houndmills Basingstoke, Hampshire: Mcmillan.

Johnson, I. 2001. Introductory Lecture on Shakespeare's Hamlet, A Lecture prepared for English 200 and revised for English 366: "Studies in Shakespeare”. [Online]. Available: http://records.viu.ca/ johnstoi/eng366/lectures/hamlet.htm [2011, November 6].

McDonald, R. 1996. The Bedford Companion to Shakespeare. An Introduction with Documents. Boston, New York: Bedford Books of St. Martin's Press.

Olaru, A. 1976. Shakespeare şi Psihiatria Dramatică. Craiova: Editura Scrisul Românesc.

Percec, D. 2006. The Body's Tale. Some Ado about Shakespearean Identities. Timişoara. Editura Universităţii de Vest.

Rose, J. 1985. Sexuality in the Reading of Shakespeare. Hamlet and Measure for Measure, 97-120 in Drakakis, J. Alternative Shakespeares. New York: Routledge.

Verdon, J. 2009. Dragostea în Evul Mediu, Trup și sexualitate. București: Humanitas. 


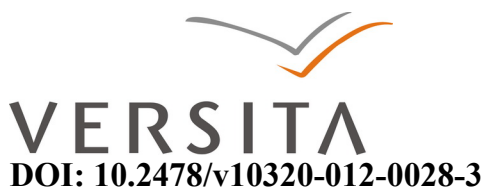

“IN THE HEAD OF THE WORTHIEST WOMEN":

AMAZON QUEENS AND PERFORMING HEROINES IN

JACOBEAN COURT MASQUES

\title{
MICHELE DE BENEDICTIS
}

University of Cassino

\section{Via Guglielmo Marconi, 10, 03043 Cassino Frosinone, Italy michelergo@alice.it}

\begin{abstract}
Queen Anne of Denmark's role - as actress and patroness - in emancipating womanliness onstage by direct performance is strictly connected to the emerging trend of fashioning masques in the early Jacobean court. My paper will focus on the connection/contamination of this dramatic phenomenon with the current imagery of acting warlike heroines, conflicting Anne's policy for entertainments with masculine and royal anxieties.
\end{abstract}

Keywords: Amazons, Ben Jonson, Jacobean court, masques, Queen Anne

THESEUS Hippolyta, I woo'd thee with my sword, And won thy love doing thee injuries; But I will wed thee in another key, With pomp, with triumph, with revelling.

(William Shakespeare, A Midsummer Night's Dream, I.i.16-19)

In Act I scene II of Timon of Athens, Shakespeare - probably with Middleton's collaboration - introduces on stage his sample of disguised Amazons as masquers for upper-class entertainment. During the banquet, a group of dancing ladies, halfway between modern showgirls and classical prostitutes, enact a licentious spectacle of flattering sensuality before the euphoric Timon, while Apemantus's asides condemn them as emblems of the corrupt debauchery of contemporary Athens, since he perceives contact with their revelling bodies as an infective source of physical and moral contagion 
for society (Fulton 1979:288-90). There are no stage directions or textual details for their costumes and specific movements during this teasing show, but the routine prejudice against female performers for displaying their moving (theatrical) bodies as magnets for pleasing male gazes seems here partially lessened by the fact that actually these Amazons, apart from the dramatic diaphragm provided by the stage, were not women at all (in Jacobean revenge tragedies by Webster and Middleton, female characters attending court festivals and masquing revels are often charged with over-indulgence in dissolute pastimes and sexual incontinence. Cf. Butler 2008:128-29).

Indeed, in English Renaissance drama all female roles were canonically filled by professional male players suitably cross-dressed: formally, the acting stage was forbidden to real women, who did not at that time put their own identities and reputations at risk in common playhouses in order to attract attention as theatrical artefacts, even if within a fictional context. Their appeal as fetishised objects of male desire proved to be less tangible in theatres precisely because of the concrete absence of real female bodies on display.

This angle, projected towards theatrical seduction, proves to be further complicated if we consider that Amazon imagery already includes many ambivalent elements that lie on the borderline between genders, often with implications of repulsion (Carney 2003:117-18). Commonplace sources, ranging from classical mythography to Early Modern accounts from exotic lands, describe them as unruly women committed to transgress those formal codes imposed by men on their sex, subverting a (supposed) natural and patriarchal order in exercising male prerogatives. Thus Amazons were generally portrayed as aggressive un-domestic women, cruel devotees of hunting and war, fiercely proud in their self-seclusion from male communities, and free to exercise their androgynous chastity or brutish lust without men's consent. Their femino-centric attitude was commonly branded as a barbarous instance of rebellion against the precepts of a traditional civilisation which was still dependent on the ideal paradigm of passive women, subjected to male control and bereft of "performative" places to exhibit their warlike virtues through an antagonistic stance.

During Elizabeth I's reign this paranoid bias against the unwomanly monstrosity inherent in Amazonian tropes had been reduced by the crucial impact of a powerful 
female ruler - remembered as divina virago for her celebrated speech at Tilbury on the eve of the battle against the Spanish Armada, and retrospectively depicted as an Amazonian queen (during her lifetime, probably to avoid any allusive inconvenience, Elizabeth I was never officially compared to, or associated with, Amazon warriors, both in panegyric works and public entertainments).

These bellicose masculine elements related to Elizabeth's virtues enhanced her popularity, yet without impairing her womanly identity. Amazons no longer met with scornful overtones, while their militant heroism was progressively rehabilitated through oblique correlations with the Tudor sovereign (Jackson 1988:49-52). In this period diverse entertainments offered as official tributes to Elizabeth featured Amazons in a more favourable light, though their roles were still performed by male actors as in public theatres (Schleiner 1978:163-68).

James's accession to the English throne by 1603 - as a king well-known for his misogynistic attitudes and strategic hostility to war - justified the tendency to invert this process, and Amazons were increasingly re-perceived as a symbolic threat to ruling male sovereignty, and accordingly condemned for being agents of disorder/subversion who fostered male anxieties about gender hegemony through their illegitimate appropriation of manly privileges - as well as evoking by parallel the nostalgic spectre of Elizabeth's militant heroism, so dangerous for James's policy of self-propaganda (Orgel 1990:12326).

Theatrical Amazons in Shakespeare and Fletcher's Jacobean tragicomedies, after a riotous preamble of conflict, are conventionally tamed to be re-shaped as respectful consorts, subaltern to their triumphing husbands and rulers (see, for instance, The Two Noble Kinsmen (1614) and The Sea Voyage (1622), once they have shed their inborn warlike attitudes to fulfil a romantic happy ending of familial reconciliation and incorporation (Carney 2003:121-26). The first relevant encounter between Shakespeare's drama and mythical Amazons, however, dates back to his comical production in Elizabethan period. In A Midsummer Night's Dream, the character of the warrior-queen Hippolyta anticipates that condition of obedience to her husband (Teseus) recurring for Amazons in future tragicomedies. (Cf. Carney 2003:119-21) 
Those who try to resist this scheme are doomed to ill-famed banishment giving way to self-destruction, as in the tragic case of Fletcher's Boadicea, the martial Queen of the Iceni fighting against the Roman occupier, protagonist of The Tragedie of Bonduca. Her defiant and Amazon-like attempts to subject the enemy (male) soldiers to an emasculating form of disarmed captivity turns out to be condemned even by her countrymen as an immoral war crime; militant heroism seems here to repel women's deviant intromission into warfare, previously regarded as exclusive territory for male authority (Crawford 1999:362-66). Obviously, this attitude, once transposed from the stage to the contingent self-assumption of kingship, could properly conform to James's absolutistic and misogynistic perspective of patriarchal rule, imposed as a norm on all his subjects, including his restless wife (formerly princess of Denmark, and Queen of Scotland when her husband had reigned there as James VI) Queen Anne. Nevertheless the queen consort - the first after more than fifty years in England, and actually James's first loyal subject and closest courtier - did not acquiesce in submissively accepting this position, and now and then reacted to this autocratic male policy with strategic acts of resistance, more or less implicitly, always circumventing a strenuous posture of overt antagonism.

The first auxiliary channel elected by Anne to counterbalance a super-imposed male-centric scenario at court consisted in the cultural activities promoted by her own private circle and household, a centre of influence and political identity alternative to that of the King. The Queen was surrounded by eminent scholars and artists in her private court; she was universally renowned as a patroness of culture, extending the promotion of her power and dignity through the renowned contribution of cultural innovation. This dynamism could be plainly ascribed to the contingent interplay between different circles within the Jacobean court which, far from being a monolithic structure of uniform interests, actually involved a complex network of factions competing for primacy in influence and lustre. Furthermore, during their years in England, Anne gradually lost a conspicuous amount of James's esteem and attention - carnally too - becoming gradually detached from his private life, to be replaced by his male favourites, and barely tolerated for her meddling in the King's public affairs. In this context of increasing distance and disaffection she sponsored a particular type of dramatic entertainment to voice her 
(female) authority and disturb, without a direct offensive, the rhetorical monologue of James's masculine assertiveness (Lewalski 1993:19-23, 43).

By 1603 the court masque was a theatrical genre still uncoded and open to experimentation. Being considered an instrument for royal propaganda, whose task consisted in allegorically celebrating the royal majesty at suitable annual festivities and state events, these court entertainments were commonly deemed direct emanations from the throne, liable to mirror its inherent priorities within a context of stately revels. Nevertheless, Queen Anne strove to modify this implied canon, aiming primarily to promote her royal persona in opposition to previous standards, taking part in a radical recontextualization of conventions for masques which can be seen as evidence of female influence over court activities (Wynne-Davies 1992:80-82).

The usual formula of court masque provided a dramatic interaction between professional actors playing speaking parts and mute gentlemen disguised as masquers. Elaborate dances and songs matched their acted performances, which canonically culminated in inviting the noble audience to an inclusive ritual of revels, alongside the feasting banquet. Generally, the initial section of these ceremonial exchanges between playing characters and the noble audience respected a specific gendered etiquette: each gentleman masquer took from the onlookers a (pre-selected) noble lady - married or not - to involve her in dancing, according to the eminence of their position or factional partnerships (a complete analysis of the ritual scansion of masque in specific choreographic phases is discussed in Barroll 2001:84-88, 94-97).

Beyond political concern, this ritual of union symbolically celebrated the prolific alliance between the two sexes, a harmonious instance of heterosexual integration projected to symbolise fertility and social continuity through generative conjunction. The official occasions for masques were also often associated with strategic marriages among the prominent members of the nobility (Lanier 1999:328-31). The first source of sensual desirability in this practice, however, depended strictly on the exclusive ability of masquing lords to show their bodily skill in extremely refined dancing - reserved to male courtiers - and combined with the elaborate pomp of their theatrical costumes: the overall extent of female display, in this case, was overshadowed by the Lords' performative 
preeminence, and circumscribed barely to complement this affected parade of male masquers, through the modest hubris of a deferential attitude (Ravelhofer 2009:108-11).

When, as main patroness, Queen Anne appointed Samuel Daniel and Ben Jonson as official dramatists for writing court masques, this fashion evolved into an innovative multi-gendered perspective during the following decade, the period remembered for Anne's leadership in court entertainment. This cycle began with Samuel Daniel's The Vision of Twelve Goddesses (1604), the first court masque - and likely also a public theatrical work in Renaissance England - to include a group of women playing a series of female characters. Differently from England and according to the sixteenth century tradition of Scottish court entertainments, female performers were already tolerated on public occasions, which James and Anne directly enjoyed during their regency in Scotland. (Cf. McManus 2002: 68-90)

These performers weren't ordinary courtiers, but the choicest ladies of the Queen's circle, playing the part of twelve ancient deities - among them Venus, Diana and Astraea - before an audience composed of the highest ranks of the kingdom along with eminent diplomatic guests (McManus 2002:101-105). Anne chose for herself during the staging the independent role of Pallas/Athena, the warlike and virginal goddess reputed to represent wisdom and learning: she deliberately rejected the part of Juno, queen consort of Jupiter in Olympus, to give specific emphasis to her autonomous image, once disconnected from the ordinary conjugal subtext intended to celebrate the royal couple.

In his dedication to Lucy, Countess of Bedford, Daniel did not omit to illustrate how worthily Pallas's part was played by 'the magnificent Queen' also remembered for her 'heroicall spirit' (Daniel 1981:25) in embodying this mythical figure. In the main masque, moreover, her praiseworthy profile is enhanced by the description of the armed Anne/Pallas, as viewed by her charmed audience, who shows off onstage supplied with all the symbolic paraphernalia typically related to this goddess, including veiled allusions to the Elizabethan imagery of the warrior queen, whose militant aura Anne seems here to inherit as figurative echo. Probably Anne adapted for this masque an old dress from Queen Elizabeth I's wardrobe as costume for Pallas, exactly to express a sign of female continuity inside the English court by re-embodying the features of her illustrious predecessor. (See McManus 2002: 107-109) 
She feels more inclined to be inspired by the previous Queen's divine attributes than to mirror any simplified version of male heroism within a womanly dramatic body:

\footnotetext{
Next war-like Pallas, in her helmet dressed

With lance of winning, target of defence:

In whom both wit and courage are expressed,

To get with glory, hold with providence.
}

(The Vision of the Twelve Goddesses , 11. 294-7)

No longer marginalised to (co-)operate merely as ideological support for complementing royal male agency, through Anne's involvement, the noble ladies in the guise of silent performers achieved an unprecedented centrality in court entertainments by exposing onstage their moving bodies to signify their self-sufficient priorities and virtues evoked by a female-only pantheon. This opportunity permitted them to establish a physical contact directly with spectators' senses unprecedented for court gendered theatricality, upsetting even the traditional sequence of taking-out for revels, because in this case ladies were assigned to invite their lords to dance. Moreover, this rearrangement of masquing roles enacts a dual display of performance never allowed to noblewomen till then: at once they could both interpret a fictional part and represent their own stately identity as illustrious ladies in public events of lofty prestige (Gossett 1988:96-97).

These features were significantly expanded and amplified by Anne's creative partnership with Ben Jonson for his first exploits in the composition of court masques. Prefaces and dedicatory addresses to the Queen are explicit in the published version of these scripts: Jonson himself declares that Anne's contribution to the dramatic invention was determining as an agent of inspiration for topical choices (on Anne's self-assumed authorial agency over the text, contrasting with the exclusive notion of male writer/printer, see Wynne-Davies 1992:79-80; and Bernadette 1999:247-49).

No inert patroness limited to raising funds for the staging, the Queen became involved in conditioning the parameters of theatrical representation, adding new ideas and imprinting her personal contribution of female authorship on the overall production: her interventions in the conceptualisation of masques ranged from the supervision of 
scenery, theatrical properties and the styling of costumes to the selection of players and the tactful policy of official invitations. Anne's scrupulous regard for these spectacles is further substantiated by her personal involvement in the rehearsals and scenic tests before the "debut" of her masques (Lewalski 1993:36-37), signalling the crucial weight of a successful exploit in these events for the Queen's renowned status, which clearly also depended on the theatrical arena of court entertainments produced by herself.

The first outcome of this fruitful collaboration with Jonson took place at Whitehall, in the Banqueting House, for Twelfth Night 1605 (see also Barroll 2002: 99104). In the Masque of Blackness the Queen and her ladies are downgraded from Daniel's goddesses to the semi-divine degree of fair Nymphs of the River Niger, who introduce themselves onstage with a distinctive remark, self-evident at first sight: by explicit order of Anne, all the Nymphs appeared disguised as blackamoors, their faces and skin painted with dark makeup to embody exotic origins from sunburned lands.

Needless to say, this provocative novelty was planned to disappoint the traditional expectations of the audience, by stirring their routine sense of decorum coupled with the aesthetic agenda of court entertainments: is it legitimate for a woman, especially for the Queen, to embody the signifiers of ambiguous "otherness" as ciphers of her royal beauty before a public of illustrious guests? Does it seem appropriate to show off her arms and shoulders naked to express freely the fertile sensuality of the royal consort's body - six months pregnant during those weeks - in a black hue? Dudley Carleton's contemporary response, in his famous epistolary accounts of this masque, witnessed the occurrence of anxious and hostile perceptions in reaction to such an innovative stance. Carleton associated the lady masquers more with dissolute courtesans than with pure nymphs, and finally turned to blame the ugly sight of blackness as unworthy of noble individuals, above all if they were representatives of the English court before visiting diplomats (Carleton 1972:68).

Apart from prejudicial embarrassment about gendered etiquette, Carleton's remarks signal the difficulty of digesting Anne's unorthodox approach to theatrical femininity, which implies a provocative transgression of codes here defied by new forms of aesthetic misrule imposed by a (ruling) woman, who compensates for the denial of speaking parts with the eloquent rhetoric of mute bodies, put in evidence onstage by their 
spectacular revision of female beauty. Instead of a mannered form of Amazonian bravery, the Masque of Blackness proposes a thorough management of womanly - and unstable beauty as a major resource/weapon for stating the militant voice of highborn ladies outside a male-only chorus of agreement (Aasand 1992:278-80). In Anne's dramatic project of self-fashioning, femaleness thus collides implicitly with previous representation of royalty and, besides, thanks to their emblematic entry, her mute masquing ladies collapse the canonical dichotomies of beauty (black/white, exotic/native) to put into question even the central authority of male personifications in a context where female expressive energy tends to prevail (Bernadette 1999:252-56, 264-67).

Finally, the miraculous Sun, as allegory for the King, is theatrically ineffectual and removed to the margins: he doesn't bleach the Nymphs' skin as promised, and leaves their problematic quest for definitive beauty unresolved. Moreover, as usual in Jacobean royal masques, James didn't establish any bodily contact during the final revels because he refused to dance in public, thus showing, as static observer, his different condition from the Queen's multimediatic poetic, fulfilled by means of visual agency and kinetic measures of dancing. The key characters and living celebrities onstage remain therefore women playing other women, who generously lavish the spectacle of their polymorphic grace within a theatrical frame.

Three years later, a new masque sponsored by Queen Anne and written by Ben Jonson was staged at Whitehall: the Masque of Beauty (1608) takes up the same Nymphs as the previous scenario, who this time appear already whitened, completing their progress towards another form of beauty applicable to their flexible royal status. The cathartic process of bleaching has occurred off-stage and the effective merit has been ascribed to the moon goddess Aethiopia, who prevailed over envious Night in a singlegendered conflict between female deities which, even if not represented, represents the turning point in the dramatic structure of this entertainment verging on the redemptive force of chromatic metamorphosis. In her essay about confessional dissimulation and chromatic disguising in masques, Molly Murray intriguingly argues for a metaphoric connection between cosmetic mutability and masking of religious sectarianism - above all considering Anne's recent (and delicate) conversion to Roman Catholicism (Cf. Murray 2007: 437-43; and Schwarz 2000:119-20). 
To confirm women's dramatic priority in this sense, in one of the closing songs, Jonson emphasises the dignity of the masquing ladies by commending the importance of female performance within that cosmic harmony here theatrically adumbrated:

\section{SONG}

Had those that dwell in Error foul,

And hold that Women have no Soul,

But seen these move; they would have then

Said, Women were the Souls of Men.

So they do move each Heart, and Eye,

With the World's soul, true harmony.

(The Masque of Beauty, 11. 307-12; see Jonson 1969:73; for all quotations from Jonson's masques in this essay the reference edition is Orgel's complete collection reprinted in 1969).

Each gentleman masquer has to acknowledge his dependence on the prestigious contribution of women for the dynamics of court society: only impious people may believe women have no souls, while it is repeatedly demonstrated that, by permeable influence, they represent men's soul instead, out of their faculty for inspiring lively movement and noble vocations. This ideal faculty can be translated figuratively to the dramatic body of the Queen's masques as well, where woman's acting constitutes the animating principle, the proper soul of masque, that gives life to magnificent delight and "moving" the senses of the involved audience with the appeal of performative transport (Tomlinson 2005:19-20, 29-30).

A more striking approach to gender issues is exposed in Jonson's third contribution to the Queen's masque, entitled the Masque of Queens and presented for Candlemas 1609. Anne asked Jonson for a 'spectacle of strangeness' for the sake of variety, a grotesque prelude of (attempted) disorder and subversion working as introduction to the virtuous queens impersonated by her ladies; something similar to a foil conceived to exalt their positive qualities by contrast. This successful formula, baptised as antimasque, from then on became an indispensable element in the structure of court masque. In this case the antimasque features a meeting of ugly witches trying rather ridiculously and vainly - to subvert natural order and conformist ethics to disrupt the king's official celebrations. Their bizarre movements and deformed appearance, 
although purposely unrealistic, disclose that utmost degeneration of female dignity much feared by the other sex in a preposterous milieu (Ravelhofer 2009:190-94).

As conventional for speaking parts, all the roles in this antimasque were assigned to professional male actors, fitly cross-dressed in the frightful guise of twelve malicious witches as emblems of chaotic indecorum. What Jonson combines here through the Masque of Queens - for the first time in English court entertainments - is a duplicitous stance of femininity that takes place onstage, where the negative pole is figured by lower class players disguised as women, with their systematic abuse of dramatic license in their manners or speeches. On the other hand, facing this theatrical turmoil, the ideal paradigm of positive femininity belongs exclusively to the real cast of aristocratic ladies performing historical and mythological Amazon-warrior queens, although without speaking parts. This strategy of theatrical juxtaposition contributes to complicating any standard perception of a single femaleness, whose fluid exegesis reveals, nonetheless, how the different representations of gender have been fluidly interpolated by the artificial filter/layers of those dramatic devices - intensely encouraged by the Queen - the audience is fully aware of, but fascinatingly perplexed by as well.

To enact a brief interlude of male intervention between these (seeming) polarized extremes of femininity, as well as to exorcise womanly hegemony in this masque, Heroic Fame appears onstage in the garments of Perseus, who does not miss the chance to vaunt his execution of Medusa - as embodiment of archetypical feminine Terror to be obliterated by masculine heroism. This linear form of implicit triumph, however, does not succeed in concealing all the ambiguities pertaining to Perseus's alleged singlegendered victory when untied from womanly influence. On the contrary, the classic myth demonstrates how Perseus mediated between two greater forms of female power only to strengthen the more virtuous one (about Perseus's troublesome relationship with female paradigms of power in mythology, see also Orgel 1990: 128-9; and Butler 2008: 139-40; for the feminine implications of the Gorgon's archetype, see Meskill 2005: 198202).

Accordingly, he was usually portrayed as mere human agent of the will of Pallas, who presided over the achievement of his mission; after slaughtering the Gorgon, he offered the spoils of Medusa's head as a votive gift to Pallas, and it promptly became an 
emblem of female power once it was appropriated by Pallas and incorporated into her powerful shield - the Agis (Schwarz 2000:122-23).

Heroic Fame/Perseus's dramatic task in the Masque of Queens, analogous to a theatrical scarecrow, consists of dispelling the anarchic Sabbath imported by the witches, in order to make room for introducing the majestic setting of the House of Fame, where the twelve heroic queens reside, whose epic reputation has been declared sublimate by male poets and historians. The names of these queens evoke glorious deeds over the centuries: it is her Majesty's grace to offer their Amazon-like spirits the chance to revive onstage by pervading the acting bodies of twelve illustrious ladies, including the Queen herself.

The composite array of these heroines heralded by Perseus includes, among the eleven women monarchs, the evocative name of Penthesilea - the proud Amazon Queen - whose fame still resounds as leading figure amongst the Trojan army for her brave duel against Achilles; Artemisia, militant regent during the absence of her husband, and always celebrated for her chaste fidelity; the noble queen Boadicea, eulogized for the tenacious defence of her people's freedom in wartime; the bold Valasca, legendary queen of Bohemia, leading the rebellion of a triumphant female-only army against male unjust tyranny. The (pseudo)historical nature of their deeds precludes a restrictive reading of these figures limited to the allegorical dimension of masque: the evidence of narrated facts testifies to the eminence acquired by the queens, whose belligerent and androgynous spirit has bereft men of their typical sphere of rhetorical exercise in warfare (Lewalski 1993:37-39).

The sum of these exemplary queens is achieved by the twelfth one, Bel-Anna, the ultimate reference for all heroic queens, the all-embracing embodiment of womanly majesty epitomised in the actual uniqueness of the living Queen Anne, who here interprets herself as repository of female militant virtues and great contemporary myth at James's expense, even when, 'far from self-love', she is described as honouring her husband's solar magnificence as primary dispenser of her radiant worth:

PERSEUS. These [Queens] in their lives, as fortunes, crowned

Of womankind, and 'gainst all opposite voice, [the choice

Made good to time, had, after death, the claim 
To live eternized in the House of Fame.

Where hourly hearing (as, what there is old?)

The glories of Bel-Anna so well told,

Queen of the Ocean; how, that she alone

Possessed all virtues, for which one by one

They were so famed.

(The Masque of Queens, 11. 386-96) Jonson 1969: $136{ }^{i}$

After Perseus's announcement the last scene begins, during which the Queens proceed descending from the House of Fame to sanction directly their celebrative grandeur. They mount three chariots drawn by fanciful beasts and by the witches, now yoked to the service of the Amazon sovereigns, but taking part in the general revelling thanks to Bel-Anna's fascinating power, which seems here able to conflate into a single collective form the negative feminine, associated with these inoffensive witches, and the noble womanhood of warlike queens, by incorporating low class players of antimasque still disguised as horrible hags - into the final dances without a hint of conflict or challenge (Tomlinson 2005:31-33). This inclusive instance of silent, and heterogeneous, sisterhood materialises into a theatrical vision the moving outcome of women's political agency in the masque, when all surface polarisations of femaleness are dissolved to allow the coexistence of disturbing factors coalesced against patriarchal conformism (Cf. Wynne-Davies 1992: 84-65; and Orgel 1990: 131-34, for an interpretation more in accordance with James's final (and fulfilled?) need of preponderance over womanly selfassertion, at the closure of this masque).

The suggestive import of transgression enacted previously by the witches does not disappear at last, but turns out to be inherent within the frame of heroic queenship which, on the other hand, has already displayed its predisposition to visual sensationalism through the conscious eroticism of the noble ladies' Amazon-like bodies, clad in seethrough dresses embroidered with martial symbols.

It is interesting to discern in these masques the controversial position of Ben Jonson, a dramatist well-known for his misogynistic satire, and pressed at court between James's - who was anyhow his principal sponsor for those entertainments not organised by the queen consort - and Anne's concerns for theatrical control of masque content (and 
styling). Jonson afterwards attempted an inconsistent policy of partial mediation to contain Anne's theatrical exuberance by suppressing some gendered elements that had seemed to him too conflictual during the performance to be tolerated again, especially in the published retrospective of these masques. His prevailing textual stratagem here consisted in subtly erasing part of the ladies' visual magnificence in order to endorse James's obscurantism about female worth.

As already said, being silent characters, the lady performers had to circumscribe all their signifying stances on the figurative plan. Yet, while masque-writers such as Daniel and Campion reserved detailed descriptions of rich costumes worn by gentlewomen during masques as organic to their solemnity - either textually in their authorial report of the show, or by the indirect accounts by speaking characters within the masque - Jonson put to silence these fashioned elements by employing only brief and deferred hints about the ladies' acting bodies or wardrobe, the extant information about which today is deduced mainly from Inigo Jones' graphic sketches or from the reports written by viewers who attended the performances. In place of women's meaningful clothes, Jonson's descriptive sections focus more on stage machinery, symbolical devices and allegorical tropes. This restrictive unease appears more problematic if we consider how much attention the Queen and her ladies devoted to selecting materials, garments, colours and the style of costumes to personify their figurative priorities onstage (McManus 2002:122-33).

What is more, a biographical and scholarly summary, with notable deeds and worth of the Amazon-like rulers in The Masque of Queens, is barely appended to the margin of the edited text in the form of erudite footnotes and glosses: in practice, during the performance, their heroic depth was only slightly - and intuitively - inferred by their legendary names, but no detailed allusion took place in the dramatic speeches. All the martial narrations related to their virtuous acts remained actually unbreathed and implicit during the staging, which rather relied on the audience's cultural background and swift aptitude in meta-historical associations.

For almost a decade Queen Anne's theatrical "alliance" with masque writers tried to resist a male form of despotism in taking over the management of court entertainment: yet, James's notorious homoerotical fondness for gentlemen highly skilled in dancing 
represented a continuous threat for women's agency over dramatic spectacles. It is not a coincidence that the increasing influence of royal favourites over James, such as Robert Carr and George Villiers, contributed to gradually suppressing the presence of female performers within court masques. After 1612 the Banqueting House, as main location for court masques, became the sole property of a homosocial coterie celebrating the King's delight, whose emasculated priority took pains to remove from the Whitehall stage the masculinised and Amazonian valour of performing ladies, now displaced by the effeminised rule of the King's "pet" courtiers.

Queen Anne's gradual withdrawal from court entertainments proceeded parallel to the twilight of her political and cultural influence. Daniel's Tethys' Festival (1610) and Jonson's Love Freed from Ignorance and Folly (1611), both patronised by Anne, still contain noble ladies as masquers: their main function in these spectacles, nevertheless, consists in honoring Prince Henry's official investiture into the world of adults, or in eulogising James's redeemed ability as ruler of his country (Butler 2008:36-37). The claim for womanly self-sufficient authority onstage was subordinated to the contingent (but illusory) sense of a united royal family.

Nevertheless, a few masques featuring noble ladies as performers were staged after Anne's climatic zenith, although, in these cases also, their topical pattern was not oriented to a militant revanche of female theatrical heroism. Thomas Campion in his Lords' Masque (1613) included eight female statues brought back to life by an almighty male deus ex machina, whereas Lucy Russell, Countess of Bedford, the Queen's chambermaid and performing lady in Anne's previous masques, paid homage to her here remembered as Pallas again - through a masque written by Robert White and entitled Cupid's Banishment (1617). This spectacle, which emphasised the chaste beauty of gentle love, was exceptionally enacted by the students of the Ladies' Hall, in Deptford, generally considered the first girls' school in England: its staging took place at Greenwich Palace, the country residence of Queen Anne, a more informal and private location than Whitehall court, as an alternative site of factional authority dislocated from James's theatrical regimen of supervision. Probably Cupid's Banishment featured the first dramatic verses spoken in public by an English woman -Ann Watkins in the role of 
Fortune (for an exhaustive study of Cupid Banishment related to Anne's involvement, see McManus 2002:188-201).

The same year Lady Lucy Hay proposed a Masque of Amazons - now lost featuring a mainly female cast for James's court, but it was preventively censored so as not to alter the outline of new royal male-centric festivals, for which Jonson had to become the chief dramatist in the matter of court entertainments for all the remaining years of James's reign.

\section{References}

Aasand, H. 1992. "“To Blanch an Ethiop, and Revive a Corse": Queen Anne and The Masque of Blackness' in Studies in English Literature 1500-1900, Vol. 32:2.

Barroll, J. L. 2001. Anna of Denmark, Queen of England: a Cultural Biography. Philadelphia: University of Pennsylvania Press.

Bernadette, A. 1999. 'Black Skin, The Queen's Masques: Africanist Ambivalence and Feminine Author(ity) in the Masques of Blackness and Beauty' in English Literary Renaissance, Vol. 29.

Butler, M. 2008. The Stuart Court Masque and Political Culture. Cambridge:

Cambridge University Press.

Carleton, D. 1972. Dudley Carleton to John Chamberlain, 1603-24: Jacobean Letters, ed. by M. Lee jun. New Brunswick, N.J.: Rutgers University Press.

Carney, J.E. 2003. “"Honoured Hippolyta, most dreamed Amazonian”: The Amazon Queen in the Works of Shakespeare and Fletcher' in C. Levin, J. E. Carney and D. Barrett-Graves (eds.). "High and Mighty Queens" of Early Modern England: Realities and Representations. Basingstoke: Palgrave Macmillan.

Crawford, J. 1999. 'Fletcher's The Tragedie of Bonduca and the Anxieties of the

Masculine Government of James I' in Studies in English Literature 1500-1900,

Vol. 39:2.

Daniel, S. 1981. The Vision of Twelve Goddesses (1604) in J. Rees in A. Nicoll, T.J. Spencer and S.W. Wells (eds.). A Book of Masques: in Honour of Allardyce Nicoll. Cambridge: CUP Archive.

Dunningan, S. 2002. 'Discovering Desire in the Amatoria of James VI' in D. Fischlin and M. Fortier (eds.). Royal Subjects: Essays on the Writings of James VI and I. Detroit: Wayne State University Press.

Fulton, III, R.C. 1979. 'Timon, Cupid, and the Amazons' in Shakespeare Studies, Vol.

9.

Gossett, S. 1988. “"Man-maid, begone!”: Women in Masques’ in English Literary

Renaissance, Vol. 18. 
Jackson, G.B. 1988. 'Topical Ideology: Witches, Amazons and Shakespeare's Joan of Arc' in English Literary Renaissance, Vol. 18.

Jonson, B. 1969 (1965). The Complete Masques, ed. by S. Orgel. New Haven: Yale University Press.

Lanier, D. 1999. 'Fertile Visions: Jacobean Revels and the Erotics of Occasion' in Studies in English Literature 1500-1900, Vol. 39:2.

Lewalski, B.K. 1993. Writing Women in Jacobean England. Cambridge, MA: Harvard University Press.

McManus, C. 2002. Women on the Renaissance Stage: Anna of Denmark and Female Masquing in the Stuart Court (1590-1619). Manchester: Manchester University Press.

Meskill, L.S. 2005. 'Exorcising the Gorgon of Terror: Jonson's Masque of Queenes' in English Literary History, Vol. 72:1.

Murray, M. 2007. 'Performing Devotion in The Masque of Blackness' in Studies in English Literature 1500-1900, Vol. 47:2.

Orgel, S. 1990. 'Jonson and the Amazons' in E. D. Harvey and K.E. Maus (eds.). Soliciting Interpretation: Literary Theory and Seventeenth-Century English Poetry. Chicago: University of Chicago Press.

Ravelhofer, B. 2006. The Early Stuart Masque: Dance, Costumes, and Music. Oxford: Oxford University Press.

Schleiner, W. 1978. 'Divina Virago : Queen Elizabeth as an Amazon' in Studies in Philology, Vol. 75:2.

Schwarz, K. 2000. Tough Love: Amazon Encounters in the English Renaissance. Durham: Duke University Press.

Shepherd, S. 1981. Amazons and Warrior Women: Varieties of Feminism in Seventeenth-Century Drama. Brighton: Harvester Press.

Tomlinson, S. 2005. Women on Stage in Stuart Drama. Cambridge: Cambridge University Press. 


\title{
N \\ VERS IT $\Lambda$ \\ DOI: 10.2478/v10320-012-0029-2
}

\section{JOSEPH HALL'S MUNDUS ALTER ET IDEM AND CROSS-DRESSING IN EARLY MODERN ENGLAND}

\author{
CSABA MACZELKA \\ University of Szeged, \\ 6722-H Szeged Egyetem u. 2., Szeged, Hungary \\ maczelka@gmail.com
}

\begin{abstract}
This paper argues that early modern English utopias in general, and Joseph Hall's Mundus alter et idem (1605/1606) in particular, engage in the contemporary debate on cross-dressing. After a look at the problem of early modern cross-dressing, the paper introduces Hall's work, together with some of the opinions about it. Out of the four books of the work, only the second part (the description of Viraginia/Shee-landt) is discussed here in detail, since it abounds in instances of cross-dressing and related phenomena (for example, sexual licence and hermaphroditism). In my reading, Hall's work readily joins the ongoing debate, but because of its masterful rhetorical strategies and its satirical perspective, the text poses a great challenge if one tries to accurately identify its position in that debate. Yet the text and some of Hall's other works testify to a serious interest in cross-dressing and other gender-related issues.
\end{abstract}

Keywords: Australia, cross-dressing, early modern, England, hermaphroditism, utopia

\section{Introduction}

It is quite obvious that in the early modern era, when dress code was centrally regulated by the so-called sumptuary laws prescribing the attire to be worn by people of different social ranks, both male to female and female to male cross-dressing posed a threat of some kind to established power relations. The precise extent and nature of this threat is heavily debated in critical accounts of the phenomenon, but the complexity of the issue is generally acknowledged. The secondary literature on cross-dressing is enormous. I will only refer to some of the many available critical opinions (for a recent treatment of the phenomenon, see Szönyi 2012, which lists a lot of related works in his bibliography). 
The problem is all the more complicated when dealing with English Renaissance theatre, which employed exclusively male actors, a feature that Stephen Orgel sees as "anomalous" in comparison to other European countries where either women were allowed to act, or theatre in general was forbidden (Orgel 1996:1-2). With only male actors present on the stage, and boys performing the female roles, cross-dressing is universally present in the English public theatre of the time. However, the true complexity of the problem is only revealed when cross-dressing is also directly employed in the performed play's plot, as in Shakespeare's Twelfth Night and As You Like It. Confusion is further exacerbated if the playwright goes yet one step further and himself refers to the strange gender configuration represented on the stage, as in the frequently quoted aside in the epilogue of the latter play, uttered by a boy actor actually performing a female cross-dresser's role:

If I were a woman, I would kiss as many of you as had beards that pleased me, complexions that liked me, and breaths that I defied not (Latham 1975:131).

With this said, it is no surprise that English Renaissance theatre is one of the predominant areas of critical discussion of the phenomenon. In the 1980s, important works by Laura Levin, Stephen Greenblatt, Jean E. Howard and others addressed the problem in the context of the stage. Another corpus particularly relevant to the issue is, quite logically, the $16^{\text {th }}-17^{\text {th }}$ century Puritan anti-theatrical polemic literature. When giving voice to their harsh critique of theatres (and, it cannot be emphasised enough, of many other "abuses" as well), William Prynne, Philip Stubbes, John Rainolds and similar authors frequently touch upon the issue of cross-dressing, as in the quotation below from Stubbes:

Our apparel was given us as a signe distinctive to discern betwixt sex and sex, \& therefore one to weare the Apparel of another sex, is to participate with the same, and to adulterate the veritie of his owne kinde (Stubbes quoted in Howard 1988:422).

The third corpus pertaining to the subject is of a vastly different nature. These are actual court records of cases against cross-dressers, a body of text which Jean Howard makes extensive use of in her seminal article published in 1988. It must be immediately 
noted that in the newer version of her article, Howard has added some preliminary notes, the most important probably being that "I no longer speak of a sex-gender system as a single phenomenon (Howard 1994:162, n.1.)." However, the basic structure and the conclusion are not significantly altered.

Interestingly, while in Howard's interpretation, such cases are another proof of a “sex-gender system under pressure (Howard 1988:418)," in the historian David Cressy's evaluation of similar material, they appear in a completely different light. Cressy revisits Howard's claims, and based on the "remarkably mild" sentences in the legal cases examined by him, as well as on a different interpretation of cross-dressing in some contemporary plays, he arrives at the conclusion that "neither the records of ecclesiastical justice nor the London comedies reveal, in my reading, a sex-gender system in crisis (Cressy 1996:450, 464)." Howard and Cressy represent the two extremes in the evaluation of cross-dressing, and many other positions can be found between the two poles. Without going any further into the matter right now, here I would only like to highlight that analyses of Renaissance cross-dressing predominantly rely on the abovelisted types of sources, namely: plays, anti-theatrical tracts, and juridical records, occasionally complemented by other types of texts (anatomical tracts, royal proclamations, homilies etc.) as well (on contemporary anatomical views, see Greenblatt (1988:esp.73-86), and also Orgel (1996:esp.18-24)). Royal proclamations and the homily Sermon against Excess of Apparel are studied by Garber (1992:25-28).

In what follows, I propose that another group of texts may further refine our perception of cross-dressing in particular and early $17^{\text {th }}$ century sexual and gender relations in general. Let us start from an author much cited in the literature on crossdressing: Philip Stubbes. Although he is frequently referred to in relevant studies, one aspect of his work is habitually overlooked, and this is already represented by the commonly used reference to the work, which runs simply as The Anatomy of Abuses. However, the fuller version of the otherwise lengthy title is The Anatomy of Abuses in Ailgna. Ailgna is, of course, a rather simplistic anagram for Anglia, and the book is in fact a fictional travel book in dialogue form, as is clarified right at the beginning, when Philoponus reminisces in the following way: 
I have lead the life of a poore Travayler, in a certaine famous Ilande ... presently called Ailgna, wherein I have lived these seven Winters, and more, travailing from place to place, even all the land over indifferently (Stubbes 1583:Bi ${ }^{\mathrm{v}}$ ).

Travel book in dialogue form, recounting a trip to an imagined land, Stubbes' work has easily found its way into the authoritative bibliography of utopian texts compiled by Lyman Tower Sargent (1988:3). In the present paper, I do not intend to scrutinise Stubbes' text, but following this trajectory from cross-dressing to utopias, I will turn my attention to another specimen of English utopian literature from Shakespeare's time.

\section{Mundus alter et idem and The Discovery of a New World}

The book entitled Mundus alter et idem sive Terra Australis ante hac semper incognita longis itineribus peregrini Academici nuperrine illustrate (henceforth: Mundus), purportedly published in Frankfort and authored by "The English Mercury," came out in late 1605 or early 1606 . Although there have been debates concerning its author, it is now proved to have been written by Bishop Joseph Hall (1574-1656), and also that, notwithstanding the inscription on its title page, it was printed in London (on the rather complicated publishing history of Mundus, see Wands 1980.) According to its modern editor, John Millar Wands, the text was immediately connected to Thomas More's Utopia (the German translation even renamed it to "Utopia Pars II"), and its initial popularity was comparable to that of More's book (Wands 1980:1). Its English translation, a rendering by John Healey, was published in 1609, and there also appeared plagiarised editions in 1664 and 1684. Since the critical discussion on cross-dressing seems to make almost exclusive use of English sources, in the present paper I will primarily rely on Healey's translation, which is entitled The Discovery of a New World or a Description of the South Indies. Hitherto unknown. Where only page numbers are provided, I refer to the 1614 edition of Discovery.

Nonetheless, at times I will mark important differences between this and the more faithful translation by Wands, who claims that Healey's version "might perhaps be more accurately called an adaptation" (Wands 1981:lv).

Generally, Mundus is a fictional travel book offering an exhaustive account of the protagonist's travels to the unknown Southern land, which was a fertile source of utopian 
imagination for a long time. The impact of the notion of an unknown Southern land on utopian imagination is discussed in David Fausett'book (Fausett 1993).

Its descriptive parts are preceded by a highly rhetorical and rather sarcastic debate about the usefulness of travelling (The Occasion of this Travel and the Introduction) between three characters: the French Peter Beroaldus, the Dutch Adrian Cornelius Drogius, and the English Mercury, the narrator. The debate concludes with Mercury's decision to set sail to the Unknown Southern Land in the good ship called "The Fancie", driven by the Columbus-like hope omnipresent in utopian texts of the time: "We must hope, and wee must dare (A4)" (on the so-called Columbus topos, see Appelbaum (2004:24-35)). It must be also be noted here that Fancy/Imagination is yet another frequent topos of early modern English utopias; authors often feel the need to refer to it in their prefaces, like in Francis Godwin's Man in the Moone (1638), or in Margaret Cavendish: The Blazing World (1666).

The ensuing travel account is divided into four books, each discussing a certain region of the continent, and according to the author of what is probably the most detailed monograph ever written on Hall, Richard A. McCabe, a certain group of human vices as well (McCabe 1982:100-1). The table below contains the names of these main regions in Hall's original and in Healey's translation, together with McCabe's dual division of the represented vices:

\begin{tabular}{|c|c|c|c|}
\hline Book & Hall & Healey & Vices (McCabe) \\
\hline 1. & $\begin{array}{l}\text { Crapulia } \\
\text { Yvronia }\end{array}$ & $\begin{array}{l}\text { Tenter-belly } \\
\text { Drink-allia }\end{array}$ & \multirow[t]{2}{*}{ sins of flesh } \\
\hline 2. & Viraginia & Shee-landt & \\
\hline 3. & Moronia & Fooliana & \multirow{2}{*}{ sins of mind } \\
\hline 4. & Lavernia & Thee-uingen & \\
\hline
\end{tabular}

The discussion of the regions strongly resembles contemporary travel books, and as a consequence, these sections are also quite similar to the second book of Utopia. Both textual connections are further strengthened by the beautiful maps provided with the text, which are hardly distinguishable from the famous contemporary maps by Ortelius and Mercator. Nevertheless, Hall's map of the unknown Southern Land also features a land 
called Terra Sancta. This may mark the basically moralising underlying scheme of the work, since contrary to the other depicted regions, this area seems to be uninhabited, and it bears the inscription "ignota etiam adhuc," which reinforces the moral of the descriptive parts (the vanity of all human activities - including the search for an earthly Paradise) on the level of topography as well (McCabe 1982:97-8). The English editions I accessed through the Early English Books Online did not contain any maps (on the relation of the work to contemporary maps and geographical knowledge, see McCabe $(1982: 85-90,98))$.

However, Hall's text is much more than a simple imitation of contemporary travel books or of More's masterpiece. The complexity of Mundus, with its myriad of allusions to classical and contemporary authors and works, is generally acknowledged in the critical assessments of the book. One of its early admirers, Sandford M. Slayer, puts the text into the context of late Renaissance authors, and after complaining about the general neglect surrounding Hall's work, ventures so far as to claim that "judged merely as a clever piece of literary craftsmanship, the Mundus is superior to the Utopia (Sayler 1927:322-3)." He identifies important differences between Utopia and Mundus, and through specific textual analogies suggests that the impact of Erasmus', but above all, Rabelais' works is even stronger, a point reiterated six years later in Huntington Brown's book Rabelais in English Literature (Sayler 1927:327-32; H. Brown 1968 [1933]:103-5). Wands also highlights important links between Mundus and Utopia, and sees in Hall's work one of the first dystopias in English literature, though he finds the connection between Hall's work and Mennipean satire more vital (Wands 1981:xxv-xli). In a similar vein, McCabe reads Mundus in the context of the satirical revival of the late 1590s, but at the same time emphasises the allegorical nature of the work and identifies a consistent moral agenda which is, as noted above, also reflected by the topography of the work:

\footnotetext{
[...] we may say that Mundus is a Menippean satire upon the vices of Europe written in the guise of an allegorical travelogue recounting a fantastic journey to the great Southern Continent (McCabe 1982:74).
}

Besides the above positions, Mundus is also read by some as a representative of the popular "Land of Cokaygne" tradition of imaginary lands with infinite abundance. In J. 
C. Davis's fundamental work on English utopias of the sixteenth-seventeenth centuries, Hall's text is in effect excluded from the group of "proper" utopias precisely on this basis, an opinion many would find problematic (Davis 1981:19-22). In a more recent article, Davis approaches Mundus from a different perspective, calling it "a satiric inversion of the claims of travel literature (Davis 2008:8)". A similar perspective is employed in Peter Mancall's book on the great Elizabethan travel writer, Richard Hakluyt, in which Mundus is seen as an "attack on the idea of travel," implicitly positioned against the travel accounts so popular at the time, a work that "cast colonies as dystopias to be avoided at all costs (Mancall 2007:258).” David Fausett's book is unique in that it also touches upon the question of Mundus's gender reversal, and connects Hall's work to Thomas Artus and Béroalde de Verville, who also showed interest in gender issues and hermaphroditism. According to him, Hall was one of the initiators of the "austro-hermaphrodite theme," perfected later by Gabriel de Foigny, whose La Terre Australe connue (1676) is an important piece of hermaphroditic utopianism (Fausett 1993:48-51).

As this short review of critical opinions has hopefully revealed, Mundus is informed by multiple literary traditions (utopian writing, Mennipean satire, travel writing), and this multiplicity is unified by an overarching, progressive moral agenda against vices of all sorts. Especially because of this moralising aspect, it is quite obvious that to some extent at least, the text can be read as a commentary upon contemporary social conditions, even if the commentary is expressed in an indirect way. Thus the second book of Mundus, which describes the land of woman, and includes Hermaphrodite Island, as well as Shrewes-burg, a city where gender roles are completely reversed, clearly has something to contribute to the discussion quoted at the outset of my paper.

\section{The description of Shee-landt/Woman-decoia}

Since by definition every utopia is informed by a desire to rearrange the received social order, questions of gender inevitably arise from the very beginnings of the genre. Plato's Republic is renowned for its controversial views on women's role: whereas education and ruling are open to women, they are, through the abolition of private 
families, shared in common in Socrates' system(for a clear-cut overview of feminism in Plato's Republic, see E. Brown 2010). Aristophanes, and above all his Ecclesiazusae, had a discernible influence on Hall's work, and especially on the way he depicts the political system of the land of women. While in general the Renaissance successor of the genre, More's Utopia, includes a rather conventional patriarchal order, some more novel ideas are also found in it, like the examination of the man and woman by a third party before marriage, or a rather reasonable attitude to divorce. Almost invisible in utopian scholarship, one of the early English successors of More's work, A Pleasant Dialogue between a Lady Called Listra, and a Pilgrim (1579) is a conventional utopian dialogue between the traveller and the interrogator with the slight but important change of featuring a female interrogator (A Pleasant Dialogue between a Lady Called Listra, and a Pilgrim. Concerning the Gouernment and common weale of the great province of Crangalor, London, 1579, STC $\left(2^{\text {nd }}\right.$ ed.) 18335.5$\left.)\right)$. The text appeared anonymously, but a certain Thomas Nicholas is sometimes suggested as its author. It seems to be completely neglected in utopian studies, although it is to my knowledge the first instance of a utopian text where one of the utopian stock characters is a woman. The text follows the usual pattern of utopias, describing the political-ecclesiastical conditions in Crangalor. Particularly because of the unique authorial/narrative configuration (the narrator is a Corinthian woman who even argues for writing in English in the preface - in a book with all probability written by an English man), a detailed analysis of this text would be highly desirable.

Gender relations are obviously in the spotlight in the first English utopia written by a woman, Margaret Cavendish's The Blazing World (1666), where fiction is explicitly treated as a means of gaining powers otherwise only accessible to men. As Anne M. Thell puts it, "She [M. Cavendish] attains her speaking position by locating the early modern loci of power-namely, the discourses of imperialism, science, religion, discovery, and travel - authorizing herself through them, and then harnessing them to fuel an absolute textual conquest" (Thell 2008:441).

Mundus, on the other hand, is involved in the question of gender relations in a somewhat different way, and while we are directing our attention towards the land of woman, we should keep in mind McCabe's opinion that Hall was "neither philosopher nor 
theologian, but an impassioned devotionalist deeply convinced of the moral efficacy of imaginative literature (McCabe 1982:2)."

The part devoted to the description of the land of women begins with a rather short general description of the land, performed in the usual manner of travel books, but it also contains a rather ambivalent remark:

The soile thereof is very fruitful, but badly husbanded: It is divided into many Provinces, both large and ritch, yet all of severall conditions, habites and languages $\left(\mathrm{H}^{\mathrm{r}}\right)$.

The first clause obviously submits itself to utopian conventions, plenty being one of the persistent features of utopian landscapes. However, through the inventive pun on the double meaning of the word "husband," Hall suggests that the land of women cannot be an ideal place, and the reason for this is the diversity of "conditions, habites and languages," which in turn is caused by the lack of proper cultivation. The text implies here that a land ruled by women, or rather, unruled by men, necessarily leads to confusion, but on a less institutional level, it simply means that the "unruly" woman represents danger. Correspondingly, Howard argues that female to male cross-dressing was interpreted as a sign of unruliness, which not only represented the danger of sexual licence but was also seen as a threat against the state (Howard 1988:425). The concept of unruly women as dangerous in Mundus clearly initiates a remote link with cross-dressing already at this early point, and therefore it is all the more remarkable that besides conditions and language, the third area of confusion is "habites," and also that Wands's translation only includes "character and custom" in the same place (Wands 1981:57).

This preliminary opinion gains more relevance after a crafty rhetorical twist in the second chapter, which lends some instability to the narrator's position. Since Mercury arrives from the land of the arch-enemies of women, Lecheretania, he enjoys a rather cold welcome, and only the name and the fame of his country can save him: "Well to warde I went, and but that my countries name (the true Paradise of women) pleaded for me, I had never come home alive ( $\left.\mathrm{H}^{\mathrm{v}}\right)^{\prime}$ ". Despite England's favourable gender reputation (which Wands traces back to a saying popular in the 1590s), the narrator has to accept certain laws, and thus we encounter another typically utopian textual element. Catalogue 
of laws are found in many early modern utopias (see for example Gabriel Plattes's The Description of Macaria (1641) or Henry Neville's The Isle of Pines (1668)).

The laws are incorporated into the chapter, and open a rather wide window upon general contemporary stereotypes about women, reflecting a set of supposed female desires like the possibility of talking without interruption, being the ruler of the house, male constancy and monogamy, and respect for female privacy. From the perspective of the narrator's position, the last law is of paramount importance:

That I should continually give women the prick and praise for beauty, wit and eloquence, and defend it against all men $\left(\mathrm{H}^{\mathrm{r}}-\mathrm{H} 3^{\mathrm{v}}\right)$.

Mercury thus subjects to a law which imposes on him certain narrative rules. Since this happens at the very beginning of a book dedicated to the description of the land of women, the rest of the book must be taken with a grain of salt, since negative judgments must by agreement be suppressed (or they must be uttered in indirect ways). The narrator himself refers to this ambiguous position, claiming that "my tongue is tied by mine oth [...] Somewhat I may say, but no harme $\left(\mathrm{H}^{\mathrm{v}}\right)$," and this admonition becomes all the more important when we are moving towards chapters describing more sensitive issues.

The narrative commences in the usual utopian pathway, displaying the form of government and the system of elections. This part is again full of negative stereotypes of women, and introduces a totally confused, inconstant system, where the two most important virtues are Beauty and Eloquence. In a sense, this chapter is the illustration of the very beginning of the book, suggesting once again that if women are their own rulers, confusion inevitably arises. This basic tenet is expressed almost word for word when this strange sort of female democracy is described in the following manner, right in the first sentence of the chapter:

Their state (for ought I could observe) is popular, each one seeking superiority, and avoiding obedience $\left(\mathrm{H} 3^{\mathrm{r}}\right)$.

Remarkably, the Latin original uses the word democraticus instead of popular, yet from our present perspective it is more important that the self-ruling women of Shee-landt seek 
the privilege of men (superiority), and consequently, lose what seems to be in Hall's opinion their own principal virtue, obedience. As we get closer and closer to the heart of Shee-landt, the picture of Hall's ideal female gradually emerges - but because of the satiric tone, the picture is in negative, and it was apparently taken in black-and-white, too.

Thus the position of the narrator has become rather problematic by the time we arrive at those parts which are directly relevant to the topic discussed here. The title of chapter six is Of Double-Sex Isle, otherwise called Skrat or Hermaphrodite Island, and it represents a land where everything has a "double kind," even nature itself is full of weird dualities with fruits like cherry-apple and date-almond. But it is the inhabitants of this island who are particularly interesting for the problem of cross-dressing:

Yea in so much that the very inhabitants of the whole Iland wore all their habits as Indices of a coaptation of both sexes in one. Those that bare the most man about them, wore spurres, bootes and britches from the heels to the hanshes: and bodies, rebates and periwigges from the crupper to the crowne; and for those that were the better sharers in woman kind, they weare doublets to the rumpe, and skirts to the remainder $\left(\mathrm{H} 8^{\mathrm{r}}\right)$.

Needless to say, Indices is the keyword in this passage, as it refers to the primary function of the sumptuary laws in effect at the time, which was to render class and wealth positions legible (Garber 1992:26). However, on the Isle of Hermaphrodites, dress code is not a marker of rank or wealth, but rather an outward sign of the dual sex of the island's inhabitants. The cross-dressing acted out here is very different from the cases discussed by Howard, Cressy and others, where cross-dressing means appearing in the opposite sex's attire. In Mundus, hermaphrodites wear male and female clothes simultaneously, a condition quite similar to a case noted in the mid-seventeenth century diary of the physician John Ward, which is recounted in Ruth Gilbert's monograph on early modern hermaphrodites:

An hermaphrodite at a place 4 miles of Worcester: his testicles large and his penis out of measure big yet unfit for generation as my Landlord said he did believe. I and Mr.Trap saw him. Hee goes dressed upward as a woman in a kind of wastcoat and Bodies: but Breeches on (John Ward quoted in Gilbert 2002:2). 
On the Isle of Hermaphrodites, this type of "dual" cross-dressing is not so much a means of transgressing gender boundaries, but an outward sign of the double-sexed nature. In "their conceite" the inhabitants of the isle consider themselves to be in possession of "the perfection of nature," and it must be strongly emphasised that the narrator himself comments upon this duality in the following manner: "truly you may observe in them all, besides their shapes, both a mans wit, and a womans craft $\left(\mathrm{H} 8^{v}\right)$." At first glance, we seem to encounter here an island where the hermaphrodite is "an elevated ideal, the perfect union of opposites" (Gilbert 2002:9).

Yet, despite the narrator's apparent approval, ambiguity lingers in the concept of hermaphrodites in Mundus. Remnants of conventional sexual distinctions can be observed, and these govern the direction of the "dual" cross-dressing. Some "bare the most man about them," while others are "the better sharers in woman kind," and the kind of dress he/she/it wears is an indicator of the dominant sex in the given individual. The dominant sex is also indicated by their names: "Mary Philip, Peter-alice, Iane-andrew, and George-audry $\left(\mathrm{H}^{\mathrm{r}}\right)^{\mathrm{y}}$ ”. It is clear that dressing, cross-dressing, naming, and sexual identity are closely linked in the description of the hermaphrodites in Mundus, and there are similar instances of this association in Hall's other books. Both in his early satirical work Virgidemiarum (1597-8), and in his later sermons, he engages in somewhat fervent attacks against cross-dressers, and at least in one place he refers to them as "the hermaphrodites of our times" (Wands 1981:158). The same association appears in other works written against cross-dressers, as in the famous Hic Mulier tract of 1620, where cross-dressing women are referred to as "new hermaphrodites" (Hic Mulier quoted in Howard 1988:425). Therefore, the allegedly idealised image of hermaphrodites in Mundus must be handled with caution. Although the narrator seems to be approving, he also refers to the hermaphrodites" "conceite" and "deformity," and in the typical satirical inversion of values, retells the hermaphrodites' opinion about single-sexed persons: "what a coile they keepe about them, shewing them as prodigies \& monsters, as wee doe those that are borne double-headed, or other such deformed birthes $\left(\mathrm{H} 8^{\mathrm{r}}\right)$." All in all, the isle of hermaphrodites in Mundus reinforces Gilbert's observation about the plurality and instability of the meanings associated with the early modern concept of hermaphroditism (Gilbert 2002:ch. 1, esp. 9-10). 
The last chapter of Book II is an account of the country called Shrewes-bourg, where gender roles are completely interchanged. Here again, dress and outward appearance is of central importance; indeed, these make Mercury initially realise that the land is out of joint:

\footnotetext{
Here was I truly guld; for espying persons in the habites of men, masse thought I, this is good, I am now gotten out of Womendecoia: but when all came to all, I was flat cousned with a borrowed shape: for in this countrie women weare britches, and long beards, and the men goe with their chinnes all naked, in kirtles and peticoates; spinning and carding wooll, whilest their wives discharge the main affaires of the state $\left(\mathrm{I} 1^{\mathrm{r}}\right)$.
}

The very first sign marking the mixed-up gender configuration is once again the garments worn, and only after this comes the transposition of functions, as if this were but a consequence of cross-dressing. Yet the interchange of functions is rather far-fetched: in fact men do everything that conventionally women were supposed to do, while women enjoy all the privileges that were inaccessible for them in the contemporary patriarchal system.

Dressing and cross-dressing play a pivotal role in the rest of the chapter as well. At one point Mercury compares the enslaved men of Shrewes-burg to Turkish slaves, and finds "that these distinction of habites assured mee this was a more base kinde of captivity $\left(\mathrm{I}^{\mathrm{r}}\right)$ " - but the section may be more straightforward in the modern translation:

It would have appeared to me that I was walking among some Turkish slaves, had not the dress that distinguishes them showed me it was an even baser kind of slavery (Wands 1981:64).

Slavery is all the more insufferable because of the humiliating attire, which is once again mentioned later, the men's clothes being the only filthy object in the otherwise neatly cleaned houses.

In the secondary literature on cross-dressing, charivaris and skimingtons are quite often mentioned, for example, Howard treats them as unofficial occasions where "unruly women were disciplined and insufficiently dominating husbands reproved" (Howard 1996:103). No further description of this strange collective enactment of gender tensions 
is needed, since we can rely on a similar episode in the chapter on Shrewes-burg - but with the role of the man and the woman exchanged:

\footnotetext{
She must first change attires with her husband, and then shave off all her haire, and so being ledde through the market place must stand for one whole daie upon the pillorie, as an object unto all the fleering scoffes of the beholders, nor shall the man escape scot-free, for being so audacious, as to take the favours offered by his wife without a modest refusal $\left(\mathrm{I}^{\mathrm{r}}\right)$.
}

Once again, the importance of dressing and cross-dressing is re-confirmed, the change of attire being the most substantial part of the punishment of the wife who lets her husband loose: she can only put her normal clothes back on after she produces a cudgel covered with the blood of the unruly man to the court. Let me add here that descriptions quite similar to this (as well as the topic of wives beating their husbands - but later duly punished) appear in an earlier text, in Thomas Lupton's Siquila. Too good to be true... (published in 1580 in London, STC [2nd ed.] 16951, esp. 49-50, also 60-66), which is also included in Sargent's utopian bibliography. The debt of Hall's book to this work, and to other pieces of Tudor social criticism (like Stubbes' quoted work, or the Pleasant Dialogue... ) deserves further examination.

Because of the total symmetry of the perspective employed (man do everything that would "naturally" pertain to women, and vice versa), Shrewes-burg reflects gender tension of a peculiar kind, one based on imagining a complete reversal of conventional gender roles. Through this, Mercury comes to realise that these roles are based on nothing but custom, in accord with Szönyi's conclusion about Renaissance cross-dressing, which, as he claims, "suggested that gender differences resulted only from social practice and cultural representation" (Szönyi 2012). Mundus is an apt illustration of this point, particularly in the passage below, where the narrator explicitly ponders upon this idea:

\footnotetext{
Now you would thinke it incredible if I should tell you of the neatnesse of their houses, yet the men are all their drudges to wash, wipe, scoure and sweepe all that is done: yea and dresse all the meate besides: so that I imagine that it is but mans esteeme of the undecency of such bussinesses, (not any of his unablenesse to discharge them) that makes him eschew such employments $\left(\mathrm{I} 3^{\mathrm{v}}-\mathrm{I} 4^{\mathrm{r}}\right)$.
} 
The shift of roles evidently arouses empathy in the narrator, but most of the time one feels that this empathy is reserved for the effeminated men, so cruelly humiliated by the roles imposed upon them. Here, for the first time, the narrator seems to come close to realising that male and female roles are not necessarily determined by biological sex, but are culturally and politically sanctioned. And this rather progressive stance is reinforced by other works of Hall. In one of his sermons entitled The Women's Veil, Hall condemns men who rule over their wives in a tyrannical fashion that reduces them to the level of slaves (Wands 1981:159).

\section{Conclusion}

To sum up, Joseph Hall's satirical dystopia, and especially its sections concerned with the land of women, seem to be heavily informed by contemporary gender issues, and, more specifically by the topic of cross-dressing. Whenever some sort of gender reconfiguration takes place in the text, it begins with the mixture (Isle of Hermaphrodites) or exchange (Shrewes-burg) of gender-specific attire. And the image of the cross-dressed female in Mundus readily conforms to many of the claims found in secondary literature. Let us here once again recall the two extremes in the evaluation of the phenomenon. Howard sees in cross-dressing a sign of a sex-gender system under heavy pressure, even if in her later article she calls attention to the non-monolithic nature of this system. Cressy, on the other hand, thinks that cross-dressing was much more marginal in its importance. Since Hall's book reiterates almost all the anxieties connected to cross-dressing (the unruly woman, the monster-woman, the effeminate man, the conventional basis of gender roles), it is beyond doubt that Mundus is engaged in the same discourse. However, because of the crafty rhetorical structure, the problematic position of the narrator and the satirical tone, it is not always possible to precisely identify the stance of the text.

It might also have some relevance that the anatomical aspects of sex change are left almost completely unmentioned. While in the above quoted description of a hermaphrodite by John Ward, besides the strange dual dress, private parts are also mentioned, nothing like this appears in Mundus. Even on the Isle of Hermaphrodites, we learn nothing specific about the anatomy of the inhabitants, except that they are "prefect 
both in begetting, \& bringing forth" $\left(\mathrm{H} 8^{\mathrm{r}}\right)$. The biological differences seem to be less important for Hall than the social implications of gender trouble. And this is in agreement with the supposed moralising purposes of the work, as well as with Hall's image as a typical Elizabethan figure, whose fundamental characteristic was his "learned modesty" (Wands 1981:XX). And even though it was precisely the work discussed here that Milton attacked so fervently in his An apology against a pamphlet called A modest confutation of the animadversions upon the remonstrant against Smectymnuus (1642), calling it the "idlest and the paltriest mime that ever mounted upon bank," and a "universal foolery," from this inquiry into the text from the aspect of cross-dressing, it has by now hopefully become clear that the text is an infinite source of information on many different contemporary social phenomena (Wolfe 1953:880-1).

In fact, cross-dressing has a fundamental place in the description of the land of women in Hall's book. Mundus reinforces the notion that cross-dressing was a heavily discussed phenomenon at the time, and the text readily joins this discourse. The text reveals two important aspects of contemporary cross-dressing. The first is the realisation that like dress-codes, gender roles are also customary. The other is that their interdependence is so tight that a change in one necessary causes an effect on the other. Whether these considerations refer to a general crisis in contemporary gender relations is another question. If we juxtapose the rest of the book with the chapters discussed here, we may reach the conclusion that even if there were serious problems with gender relations, there were serious problems with many other aspects of contemporary life too (at least in Hall's opinion). Thus, although here we have focused almost exclusively on gender issues, we should never forget that as Hall's book demonstrates, in contemporary culture such issues were always inextricably intertwined with numerous other aspects and contexts as well.

Acknowledgement: The publication is supported by the European Union and co-funded by the European Social Fund. Project title: "Broadening the knowledge base and supporting the long term professional sustainability of the Research University Centre of Excellence at the University of Szeged by ensuring the rising generation of excellent scientists." Project number: TÁMOP-4.2.2/B-10/1-2010-0012. 


\section{References}

Appelbaum, R. 2004 (2002). Literature and Utopian Politics in Seventeenth Century England. Cambridge: Cambridge University Press.

Brown, H. 1968 (1933). Rabelais in English Literature. London: Routledge.

Brown, E. 2010. 'Plato's Ethics and Politics in The Republic' in E. N. Zalta (ed.). The Stanford Encyclopedia of Philosophy (Winter 2010 Edition) [Online].

Available: http://plato.stanford.edu/archives/win2010/entries/plato-ethics-politics/

[2011, December 8].

Cressy, D. 1996. "Gender Trouble and Cross-Dressing in Early Modern England” in Journal of British Studies 35.4, pp.438-465.

Davis, J. C. 1981. Utopia and the Ideal Society: a Study of English Utopian Writing 1516-1700. Cambridge: Cambridge University Press.

Davis, J. C. 2008. “Going Nowhere: Travelling to, through, and from Utopia.” Utopian Studies 19.1, pp.1-23.

Fausett, D. 1993. Writing the New World. Imaginary Voyages and Utopias of the Great Southern Lands. Syracuse, New York: Syracuse University Press.

Garber, M. 1992. Vested Interests. Crossdressing and Cultural Anxiety. New YorkLondon: Routledge.

Gilbert, R. 2002. Early Modern Hermaphrodites. Sex and Other Stories. Basingstoke: Palgrave.

Greenblatt, S. 1988. Shakespearean Negotioations. The Circulation of Social Energy in Renaissance England. Berkeley: University of California Press.

Hall, J. 1614 (1609). The Discovery of a New World or a Description of the South Indies. Hitherto unknown. By an English Mercury. Translated by John Haley. London. STC (2nd ed.), 12686.3.

Howard, J. E. 1988. "Crossdressing, the Theatre, and Gender Struggle in Early Modern England" in Shakespeare Quarterly 39, pp.418-440.

Howard, J. E. 1994. The Stage and Social Struggle in Early Modern England. London: Routledge.

Latham, A. (ed.). 1975. As You Like It. The Arden Edition of the Works of William Shakespeare. London and New York: Methuen.

McCabe, R. A. 1982. Joseph Hall. A Study in Satire and Meditation. Oxford: Clarendon.

Mancall, P. C. 2007. Hakluyt's Promise: An Elizabethan's Obsession for an English America. New Haven - London: Yale University Press.

Orgel, S. 1996. Impersonations. The Performance of Gender in Shakespeare's England. Cambridge: Cambridge University Press. 
Sayler, S. M. 1927. "Renaissance Influences in Hall's Mundus alter et idem" in Philological Quarterly VI, pp.321-334.

Sargent, L.T. 1988. British and American Utopian Literature: 1516-1975. New York: Garland.

Stubbes, P. 1583. The anatomie of abuses (...) in a verie famous ilande called Ailgna. London. STC ( $2^{\text {nd }}$ ed. $), 23376$.

Szönyi, G. E. 2012. "Order and Its Subversion in Dress-Code: Crossdressing” in A. Kérchy, A. Kiss, G. E. Szönyi (eds.). The Iconology of Law and Order. Szeged: JATEPress, Papers in English and American Studies, forthcoming. Since only a manuscript version was made available, I could not provide page numbers.

Thell, A. M. 2008. “The Power of Transport, the Transport of Power: Margaret Cavendish's Blazing World' in Women's Studies 37, pp.441-463.

Wands, J. M. 1981. (trans., ed.) Another World and Yet the Same. Bishop Joseph Hall's Mundus Alter et Idem. New Haven and London: Yale University Press. (Yale Studies in English, 190.)

Wands, J. M. 1980. "The Early Printing History of Joseph Hall's Mundus Alter et Idem." The Papers of the Bibliographical Society of America 74, pp.1-12.

Wolfe, D. M. (ed.). 1953. Complete Prose Works of John Milton 1. 1624-1642. New Haven, Yale University Press. 


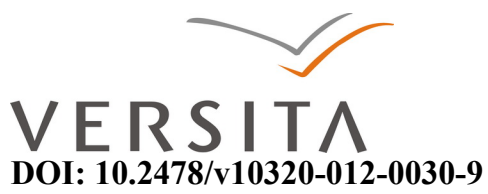

\title{
WOMEN UNDER SIEGE. THE SHAKESPEAREAN ETHICS OF VIOLENCE
}

\author{
DANA PERCEC and ANDREEA ŞERBAN \\ West University of Timișoara \\ 4, Pârvan Blvd, Timișoara, Romania \\ danachetri@email.com \\ anyon1981@yahoo.com
}

\begin{abstract}
This paper discusses notions of physical violence, domestic violence, and sexual assault and the ways in which these were socially and legally perceived in early modern Europe. Special attention will be paid to a number of Shakespearean plays, such as Titus Andronicus and Edward III, but also to the narrative poem The Rape of Lucrece (whose motifs were later adopted in Cymbeline), where the consumption of the female body as a work of art is combined with verbal and physical abuse.
\end{abstract}

Key words: consumption, rape, sexual assault, siege, violence

\section{Introduction}

The fourth act of William Shakespeare's Titus Andronicus opens with the raped and mutilated Lavinia chasing Lucius' son, gesturing at the book in the boy's hand, Ovid's Metamorphoses. She manages to turn the pages to the story of the rape of Philomela, thus informing her father and uncle about Tamora's sons' deeds. Starting from this scene, which is one of Ovid's most prominent influences on Shakespeare's plays, the paper will discuss notions of physical violence, domestic violence and sexual assault and the way in which they are socially and legally perceived in premodern and early modern Europe. Special attention will be paid to such Shakespearean plays as Titus Andronicus and Edward III, probably the best example of sexual harassment in early modern fiction, but also to the narrative poem The Rape of Lucrece (whose motifs were later adopted in 
Cymbeline), where the consumption of the female body as a work of art is combined with verbal and physical abuse. In analysing the male-female relations in these plays, the paper makes use of a series of gender metaphors: the "not-quite-dead-body" (Aebischer 2004:6), the evacuated body (Bronfen 1992:45), the besieged body, the obscene and obscene body (Nead 1992:25), where the body, consumed as a work of art, is an artistic and contained one, while the aggressed body, open and leaking, is a sign of excess and an incentive to aggressive action.

\section{The siege as a gendered notion}

The potentially double role of silence is also illustrated by a play such as Titus Andronicus, in which Lavinia's enforced muteness is, for men, both a requirement and a disquieting condition. In The History of Sexuality (1995:27), Foucault argued that silence is not just the absolute limit of discourse, but also an element that functions alongside the things said, in relation to them. We must try to determine the different ways of not saying things, which type of discourse or which form of discretion is authorised in particular situations: there is not one silence, but many. Emily Detmer-Goebel (2001:75) notices that Lavinia's silence is not only brutally oppressive (from the point of view of the rapists), but also troubling (from the point of view of the men in her own family). In this sense, both speaking and silence can be threatening. If she could speak, her testimony would endanger the criminals' freedom and life. The fact that she can't speak prevents her father from avenging his stained honour. Men depend on the young woman's ability and willingness to 'tell' about the rape. As Detmer-Goebel puts it (2001:76), "Titus Andronicus dramatically registers the culture's anxiety over men's increased dependence on women's voices and, in doing so, shapes and sustains early modern England's contradictory attitude toward a woman's accusation of rape".

Lavinia's body is, in John Hunt's formulation about Hamlet, "catastrophic" (1988:27). Hunt explains his choice of the epithet: "The human body in Hamlet forms human experience, being the medium through which men suffer and act. But the body also deforms human beings and threatens ultimately to reduce them to nothing. The nonbeing lurking at the material center of being announces itself everywhere in the play's corporeal imagery, and occupies Hamlet's mind as he tries to find his way from the regal 
death that initiates the action to the regal death that concludes it". Likewise, we may argue that Lavinia's mutilated body, and later her corpse, mediate her family's living experience and also deform their humanity (especially in Titus' case).

Lavinia's silence, unlike Kate's in The Taming of the Shrew, brings up more than just the issue of an oppressive gendered ideal of feminine decorum. Disclosing rape has a different impact from that of revealing the results of a domestic argument. Shakespeare does illustrate the fact that Lavinia's 'talking' cannot do her much good - in a way similar to Kate's problem - when he has her plead with the rapists in the 'wrong' way. She denies their masculinity by evoking images of nursing: "The milk thou suck'st from her did turn to marble;/Even at thy teat thou hadst thy tyranny." (II, 3)

The metaphorical argumentation is similar, in a way, to that of Lady Macbeth, who evokes images of sucking babes to deny her own femininity. But, in the critical situation Lavinia finds herself in, her talk is excessive because it lacks eloquence. After the mutilation, however, Lavinia does become eloquent: she persuades through the pathos of her body language, her "martyred signs" (III, 2). She becomes a discursive body - with the term used elsewhere (Percec 2006:211) to characterise Hippolyta's meaningful absence in A Midsummer Night's Dream or the marginality of the figure of the Amazon in literature. Lavinia's verbal silence helps her more than her ability to talk. Her voice is, however, potentially powerful. The rapists cut out her tongue (and not her nose, for instance - a quite common form of mutilation in times of war) not (only) to disfigure and humiliate her, but (also) out of a desperate need to silence her. After she is silenced, the rapists, relieved, mock her disability. It is true that, even before the mutilation, Lavinia is unable to talk about the rape - in this case, a moral inability - when she entreats Tamora to kill her rather than to leave her in Demetrius's and Chiron's hands:

Tis present death I beg; and one thing more

Than womanhood denies my tongue to tell:

$\mathrm{O}$, keep me from their worse than killing lust,

And tumble me into some loathsome pit,

Where never man's eye may behold my body: (II, 3) 
If the rapists need Lavinia's silence, her family needs her voice. However, as Emily Detmer-Goebel (2001:81) points out, this need is eclipsed by the way Marcus and Titus repeatedly ignore Lavinia's attempts to 'tell' about the criminals. Although Marcus immediately evokes mythological images of rape when he sees Lavinia in the forest ("But sure some Tereus hath deflowered thee,/ And lest thou shouldst detect him, cut thy tongue", II, 4), this clairvoyance disappears very soon. When Lavinia points to Ovid's Metamorphoses in the library, Marcus has already forgotten his Ovidian exclamations of some time ago. He is also shocked when Lavinia finally scratches the Latin word for rape in the sand. Titus also proves to be familiar with Ovid's story only after Lavinia's scratching of words in the sand: "Lavinia, wert thou thus surprised, sweet girl?/ Ravished and wronged, as Philomela was?" (IV, 1), and not when she shows him the Latin poet's book. Because Lavinia is unable to speak or write, both Titus and Marcus give up asking her questions very soon after the mutilation. This illustrates the fact that the recognition of women as a source of knowledge is underrated in a patriarchal society. She is not unable to communicate (as we find out from her repeated attempts to 'tell'), yet it is true that her willingness to 'tell' is undermined by her shame. When Marcus first refers to the Ovidian rape scene, it would, perhaps, have been enough for Lavinia to nod. But, just as she can't name rape in front of a woman, she can't admit having been raped in front of a man ("Yet do thy cheeks look red", notices Marcus in II, 4). Blushing is not revealing to Marcus: he can't, or doesn't bother to, read nonverbal signs on Lavinia's martyred body. The raped woman, unable to nod when asked directly, is a typical representative of a culture that prescribes silence to women in all embarrassing situations. Her cultural disability only prolongs Lavinia's torments (Scarry 1985:27).

Titus repeatedly tries to understand Lavinia (he compares her to a text or a painting several times), but it is his prejudices that prevent him from being successful. For Titus and Marcus, Lavinia cannot be a source of knowledge. And, in fact, the woman depends on the men's ability and willingness to 'read' her. Titus is too confident about his own ability to interpret what Lavinia 'tells' him to actually pay attention to her:

Hark, Marcus, what she says -

I can interpret all her martyred signs -

She says she drinks no other drink but tears, 
Brewed with her sorrow, mashed upon her cheeks.

Speechless complainer, I will learn thy thought; (III, 2)

Just as Marcus promises to "speak for thee" (II, 4) and then ignores the body language crucial for a proper translation, Titus boasts about how perfect he will be in knowing the meaning of Lavinia's 'dumb action', annihilating her as a reliable source. Through the two poor interpreters, the play emphasises men's anxiety about being dependent on women's authority, on information from them. When Lavinia has finally announced the crime and the criminals, Titus and Marcus completely forget about her. Instead of trying to comfort her, they order her to kneel for the solemn moment of swearing revenge, being more preoccupied with their own honour than hers, with the consequences of their own deeds (killing the rapists) rather than the consequences of the rapists' deeds (Lavinia's suffering and shame).

By comparison, Shakespeare's comedies deal with the theme of violence in a more covert manner. A Midsummer Night's Dream is considered - probably also because of the implications in the title - the closest to a fairy tale, to the world of magic, a play about love as imagination, about creative relationships between humans. However, this first impression may be altered on a closer reading of Duke Theseus's declaration of love: "Hippolyta, I wooed thee with my sword, /And won thy love doing thee injuries (I, 1). 'Winning love' is a common courtship trope, being found in texts that rehabilitate, in a way, the image of woman, so unfavourable in pre-modern Europe. It appears in the tradition of the so-called amour courtois, which places the woman - provided she is loved - on a higher position than the man - provided he is hopelessly in love. Love, in the minstrels' literature, installs a relationship of dependence similar to that between a lord and a vassal, between the knight and the lady. In this context only (except for the religious cult of the Virgin) does the woman become a model of all virtues and respected more than anything else. But 'sword' and 'injuries' - the instrument of violence and its visible consequences - are not part of the tradition of courtly love. Although the forest around Athens where most of the action takes place is completely imaginary, the mythological reference of the play remains valid: Theseus' taking the defeated queen of the Amazons as a prisoner and then forcing her into marriage as a cruel symbol of his 
victory. The 'injuries' suggest that, in this battle, it was not only the ordinary soldiers who became war casualties, and that Hippolyta surrendered only after she was herself wounded. The Duke's courtship speech is similar to what Proteus tells helpless Sylvia when he finds her alone in the woods, in The Two Gentlemen of Verona: "Nay, if the gentle spirit of moving words/ Can no way change you to a milder form,/I'll woo you like a soldier, at arms' end,/And love you 'gainst the nature of love, - force ye." (V, 4), where a rapist's intentions are hidden behind the metaphorical excuse of "wooing" but aggression is not absent at the discursive level because of the implications given by the "soldierly" type of treatment. The paradoxical connection between love and violence suggested by Theseus in A Midsummer Night's Dream is enhanced by Helena's comparison of the ideal relationship between herself and Demetrius with that between a spaniel and an authoritarian, even cruel master: "Use me but as your spaniel: spurn me, strike me,/ Neglect me, lose me; only give me leave,/ Unworthy as I am, to follow you (II, 1).

If there is uncertainty regarding the true attitude behind Hippolyta's silence or about the way in which Kate really sees her marriage at the end of The Taming of the Shrew, when she tells the other women that "Thy husband is thy lord, thy life, thy keeper" and that wives should "place their hands below your husband's foot" $(\mathrm{V}, 5)$, there cannot be any doubt about Helena's masochistic acceptance of Demetrius' brutality and boorishness. (We see, again, correspondences here between images of violence such as that evoked by dog imagery or Kate's placing fingers under men's shoes and those explicitly depicted by Anne in Thomas Heywood's A Woman Killed with Kindness). In Othello, when Desdemona suffers, with a similar masochism, her husband's fury, jealousy, and abuse, Emilia suggests an alternative attitude for women - that of secretly cheating on a husband as the only chance of asserting their rights and obtaining if not justice at least compensation in an epoch when divorce was inconceivable:

Why, we have galls; and though we have some grace,

Yet have we some revenge. Let husbands know

Their wives have sense like them: they see, and smell,

And have their palates both for sweet and sour,

As husbands have. [...] 
Then let them use us well: else let them know,

The ills we do, their ills instruct us so. (IV, 3)

Desdemona's misfortune is that Othello is, above all else, a soldier. Despite traditional criticism that has always presented Othello as a primarily noble character (Bradley 1970), his aggressiveness in the domestic sphere turns him into an uncouth man. From the very beginning of the play, his military career affects his love life, then his marriage. First, this happens in a positive way, as it is the Moor's very prowess on the battlefield that attracts the fair Venetian lady, accustomed to sweeter, but less spectacular talk. Then, Othello admits that his military duty makes their wedding bed one of steel when he asks her to accompany him to Cyprus. However, Desdemona proves very little affected both by this martial setting for their honeymoon and by the events that she has to face immediately after leaving her home and starting to adapt to a rougher life - the storm and the Turks that make their voyage difficult, the drunkards' roistering that wakes her on her first night in Cyprus (II, 3). Othello's problem is not that Desdemona is not 'military' enough: she understands her husband's duties and she also takes all these inconveniences much less dramatically than, perhaps, other women of her rank and breeding would have done. When the Turkish fleet is destroyed (without Othello's military intervention), the Moor is almost left out of work. Since he can no longer prove his manhood on the battlefield or, in general, in the public sphere, he grows uneasy about his private life. Iago, indeed, will characterise Othello's fits of jealousy as "unsuiting such a man" (IV, 1), that is, unsoldierly. As the security of his military identity has crumbled, Othello feels desperate that his identity as a lover and husband may go in the same downward direction. The violent drives - typical, the racial clichés go, of Muslim men - which the black general used to unleash on the battlefield will be aimed now at the person who accepted Othello's military fate with complete devotion and will destroy both the victimiser and his docile victim.

War, if not directly connected to the characters, is often a background to the comedies, suggesting, just as in the case of A Midsummer Night's Dream, a potentially violent or offending attitude men may develop towards women (Dash 1997). In All's Well That Ends Well, Bertram finds an excuse for abandoning his bride by joining in a war in 
Italy as a mercenary. Much Ado about Nothing starts with the return of the victorious army led by Don Pedro to Messina. Claudio and Benedick, the lovers in this comedy, are two of these victorious soldiers. The latter compares his friend's former enthusiasm at the sight of a war scene with his current thrill at the thought of his beloved: "I have known where he would have walked ten mile a-foot to see a good armour; and now he will lie ten nights awake carving the fashion of a new doublet" (II, 3). This is to say that a hardened soldier cannot but help having his life permanently influenced by the experience of the battlefield. The way Claudio will treat his bride has everything to do with the hardiness the ideal soldier has to display in all the events of his life.

Even Petruchio in The Taming of the Shrew proves to have experienced war when he compares the artillery "thunder in the skies", "loud alarums, neighing steeds, and trumpets' clang” (I, 2) to Kate's 'tongue'. The men who have been rejected by Kate are, for Petruchio, only 'boys', cowards who don't know that a woman has to be treated like a battlefield on which there can be only winners and losers after a brutal combat. Fierceness is the best quality of an efficient warrior and he should not give it up even in his private life - a piece of advice that Castiglione gives noblemen, unlike Shakespeare's Henry V who, before the siege of Harfleur, makes a distinction between manly domestic qualities ("modesty") and martial ones (a "tiger's" conduct). Claudio in Much Ado about Nothing makes no such distinction by preserving the tiger's cruelty when he humiliates and abandons a down-hearted bride on the day of their wedding without even caring if she is still alive or has been killed by the shock. Just like Othello, Claudio starts suffering for Hero's death only when he finds out that she had not flirted with men from the window of her room on the night before their wedding. In Hero's silence and obedience, as in that of Bianca, Kate's 'good' sister everybody wants to marry, or that of Hermione, Leontes's virtuous and faithful wife in Winter's Tale, we can immediately identify the potential victim. Faced with the 'tiger', these women have the spirits of a defeated army, of a fortress surrendering after a long and bloody siege. In Titus Andronicus, Aaron urges Tamora's sons to rape Lavinia in a metaphorical discourse that translates this crime into a hunt, as harmless as Orsino's romantic speech about hunting the hart in the opening scene of Twelfth Night. However, Aaron's presentation of the stratagem emphasises the word force: "Single you thither, then, this dainty doe,/And strike her home by force, if not by 
words:" (II, 2). The invitation to strike the hunted animal as an instruction for rape belongs to the same imagery as wooing a woman like a soldier. Men exert power over women in actions specific to their gender: fighting and hunting. The arithmetic of this strategy is simple, the equation being summed up by Demetrius in the same scene: "She is a woman, therefore may be woo' $\mathrm{d}$;/She is a woman, therefore may be won;/She is Lavinia, therefore must be loved.” (II, 1)

In a soldier's world, love is as compulsory as fighting, the very fact that the object of desire is a woman being enough to justify the tiger's conduct. Conquering a woman is not a metaphor; it is the physical translation of conquering a city or an army: by attacking, injuring, besieging, and annihilating the target. The metaphor of wooing as besieging is very powerful in Edward III, where it takes the form of both combined, as a social and political comment. The King wants to force the Countess of Salisbury to become his mistress just as he is forcing France to accept English supremacy. The armed invasion, the numerous casualties of the Hundred Years' War, increase the violent connotations of Edward's courtship. He forces the lady to swear she will obey him before she knows what he really wants. When she realises that his claim has sexual implications, she announces she will give the King her life together with the beauty of her body, her sacrifice - an indirect threat to commit suicide which is subtle enough not to voice clearly her refusal to keep her oath. The Countess's presentation of her rejection as readiness to die for the King can be compared with the token of loyalty a soldier offers his king when he dies on the battlefield, the gesture thus containing an inherent ambiguity as to the warrior's most intimate feelings (fear, disapproval of war, doubts about the leader's true intentions, etc., best illustrated by Falstaff in Henry IV and by the English soldiers at Agincourt in Henry V).

The Countess's comment on Edward's attempted rape as an "unnatural besiege" (II, 2) reflects both her disapproval of brutality in a man's relationship with a woman and a more general discontent with martial politics and with the heavy loss of human life they have as a consequence. The relationship, invested with great symbolic power, between a lord and a vassal is massively played upon here. According to Foucault (1995), docility and discipline is different from vassalage, as the former is concerned with the operations of the body, whereas the latter has to do with ritual signs of subjection, the product of the 
body's operations, and is performed from a distance. In the Countess's case, however, docility and vassalage seem to coincide, as both the King and the noble lady use a specific code and are tributary to a specific mentality, while manipulating each other in a more subtle way, supervising each other very closely.

In The Romance of the Rose, before the scene in which the jealous husband takes his innocent wife by the hair and drags her around the house, Jean de Meun contrasts the idyllic, simple life of the Golden Age when people lived without the tyranny of institutions (including royalty, army and marriage) with the age of "seigniory", of knighthood and of battles for royal claims when "High rule sets equal love aside" for "Never can love and seigniory / Travel together" (Vol. Two, C. XLVII, 8866, 8863-4). Theseus, Claudio, Bertram and Leontes are all seigniors or the King's soldiers, and their symptoms of chronic violence are immediately identifiable in Jean de Meun's descriptors. Henry V's call for equilibrium in his urging his soldiers to preserve a double nature (a "tiger's" conduct in war and "modesty" at home) remains a mere desideratum.

\section{The erased body}

Two plays that are more loosely focused on the treatment of the female body are Hamlet and King Lear. In the former, the woman's body is a vanishing body: object and improper property (Aebischer 2004), connoting instability, elusiveness, promiscuity, and ambiguity. Ophelia's deranged body and mind are presented as disruptions of the body politic. The dead female body is idealized and poetic (as shown in Gertrude's speech at Ophelia's funeral), in sheer contrast with the "regular" corpse, grotesque and decomposing (as shown in the gravediggers' scene, with Hamlet's casual disposal of Yorick's skull in the grave). Secondly, Gertrude's very presence in the play works as a sexual and political reminder ("None wed the second but who kill'd the first" III, 2), since the possession of the queen's body equals the possession of the crown. This is why the expected identification between the Player Queen and Gertrude is so crucial to Hamlet: it works as a coercion into complicity with the male-authored, male-played action. "If she should break it now" (III, 2), Hamlet muses, but Gertrude does not break, accepting the convention but being determined to remain detached, refusing to play the guilty part by identifying with the male - Claudius and the actor. "The Lady doth protest 
too much, methinks" (III, 2), she says, making herself an aesthetic and distanced member of the audience of the mousetrap, like Polonius, but unlike the empathic and involved response of Hamlet and Claudius.

In King Lear, the female characters are rudely marginalised (so little is known of Lear's daughters and their relationship with their father that their biography leaves room for endless speculation: "in need of Valium, psychoanalysis, or both," Gay 1994:177). The daughters' bodies, just like Kent's and Gloucester's, are instrumentalised only so as to amplify Lear's suffering. Thus, the play inflicts suffering both on the guilty and on the innocent, on the people involved and on the spectators. The relationship between body and speech is more conspicuous here than elsewhere: Lear has an absolute belief in the power of words, as shown in the opening scene, when he is ready to offer his daughters fortunes according to how much they claim to love him. This, combined with Cordelia's refusal to join the game and her "nothing"ness, leads to a loss of linguistic (and literal) power. Goneril and Regan usurp Lear's throne, as they usurp his power to use speech. Cordelia's initial "nothing"ness remains constant to the very end of the play, when she offers no more than a silent, unreadable body, unresponsive in her death as she seemed to be in her life: "Lend me a looking-glass;/If that her breath will mist or stain the stone,/Why, then she lives.[...] Cordelia, Cordelia! stay a little. Ha!/What is't thou say'st? Her voice was ever soft,/Gentle, and low, an excellent thing in woman. [...] Do you see this? Look on her, look, her lips,/Look there, look there! Dies.” (V, 3). Her body is a terminus, after which no restoration of a state of language is possible: "And thou no breath at all? Thou'lt come no more,/Never, never, never, never, never!” (V, 3).

\section{The body as work of art}

The Rape of Lucrece draws on the story described in both Ovid's Fasti and Livy's history of Rome. In 509 BC, Sextus Tarquinius, son of Tarquin, the king of Rome, raped Lucretia (Lucrece), wife of Collatinus, one of the king's aristocratic retainers. As a result, Lucrece committed suicide. Her body was paraded in the Roman Forum by the king's nephew, inciting a full-scale revolt against the Tarquins led by Lucius Junius Brutus, the banishment of the royal family, and the founding of the Roman republic. Ovid's poem is an extensive treatment of the official Roman calendar or Fasti, loosely imitating Hesiod's 
Works and Days, each book of which discusses one month of the Roman calendar.. In addition to some brief astronomical notes, its more significant portions look at the Roman religious festivals, the rites performed at them, and their mythological explanations. These explanations preserve much mythological and religious lore that would otherwise have been lost. Shakespeare retains the essence of the classical story, adding that Tarquin's lust for Lucrece is the result of her own husband's praise of her. Shakespeare later used the same idea in his late romance Cymbeline (circa 1609-1610). In this play, Iachimo bets Posthumus (the husband) that he can make Imogen commit adultery with him. Even though he does not succeed, he is able to convince Posthumus he has done so by using information about Imogen's bedchamber and body. Iachiamo hides in a trunk which is delivered to Imogen's chamber under the pretence of safeguarding some jewels, a gift for her father King Cymbeline. The scene in which he emerges from the trunk (II, 2) mimics the scene in The Rape of Lucrece. Indeed, Iachimo compares himself to Tarquin in the scene: "Our Tarquin thus, / Did softly press the rushes ere he waken'd / The chastity he wounded" (II, 2, 12-14). Lucrece is described as a work of art, objectified as if she were a material possession. Tarquin's rape is described in terms of besieging, with the man conquering the maiden's physical attributes. Although Lucrece is raped, the poem offers an apology to absolve her of guilt (lines 1240-46). Like Shakespeare's other raped women, Lucrece gains symbolic value: through her suicide, her body metamorphoses into a political symbol. The woman's political body is threatened by the man's natural inclination towards physical violence: the rape is presented as mutilation of Lucrece's flesh, while Tarquin's sex is a dagger or sword piercing through Lucrece's flesh. The political metaphor continues when the incident is evoked in the descriptive language of military campaigns, drawing on the violence of attacks: Tarquin's sexual impulses are equated with the spirit of a soldier marching on his foe ("By reprobate desire so madly led / The Roman lord marcheth to Lucrece' bed", 300-301); he threatens the young woman with his sword. The poem's rhetorical nature strengthens the notion of the woman's body as a work of art. The materiality of the language disrupts a rhetorical tradition oriented towards the pure idealisation of the victim and a legal tradition, and social practice, which keeps silent about rape narratives. Lucrece's own rhetorical eloquence proves that the victim seeks out a more active, violent retribution on the rapist 
and on the monarchical regime that he represents (even if the active revenge must be carried out by a male agent - Brutus).

Shakespeare's late play, Cymbeline, transforms the seduction scene into the inventory of the woman's body and bedchamber (a décor set for passion): statues of silver Cupids (as a sexual innuendo); hangings depicting Diana bathing and Cleopatra's first encounter with Antony (Diana is a chaste presence; in accordance with Imogen's good faith; Cleopatra is the embodiment of illegal love and sexuality, while Venus, passionate, seductive, and dangerous, offers an analogy between the Queen of Egypt, greeting her imperial Roman guest, and Imogen welcoming her Roman visitor in her intimacy). According to Catherine Belsey (1999:123): “Iachimo's account of the furnishings is surprisingly specific in a play which elsewhere depends on a broad generic distinction between court and countryside, punctuated by brief excursions into an equally stereotypical Machiavellian Italy". Thus, the function of the interior decorations is to enhance the credulity of Iachimo's version and to guarantee, through their symbolism, the sexual connotation of the seducer's boastfulness. In this version, Imogen's actual betrayal is of less importance than the face the husband loses in a man-to-man confrontation (symbolic or not) - Posthumus in confrontation with a man with whom he made a bet (therefore a commitment).

\section{Conclusions}

A major aspect of such plays as those mentioned above is the theatre's potential to reflect violence. They prove that tragedy not only represents an assault on the body but is also violent in its effect on the spectator, forcing a response from viewers, as well as from characters. Major motifs, such as guilt and victimisation, are embodied by characters who are rape survivors, harassed and neglected women, wives of victimisers. These characters are physical and discursive bodies: women using language to report, accuse, and avenge, women using language to claim attention or to negotiate it, men using language to perform actions upon more or less passive recipients, etc. Visualising bodies in pain (the mutilated body, the corpse, etc.) is an important part of the cultural history of their reception on the early modern stage. 


\section{References}

Aebischer, P. 2004. Shakespeare's Violated Bodies. Stage and Screen Performance. Cambridge: Cambridge University Press.

Belsey, C. 1999. Shakespeare and the Loss of Eden. London: Palgrave Macmillan.

Bevington, D. (ed.) 2003. Shakespeare's Comedies. New York, London: Pearson Longman.

Bevington, D. (ed.) 2003. Shakespeare's Sonnets and Poems. New York, London: Pearson Longman.

Bevington, D. (ed.) 2003. Shakespeare's Tragedies. New York, London: Pearson Longman.

Bradley, A.C. 1970. Shakespearean Tragedy. London: Macmillan.

Bronfen, E. 1992. Over Her Dead Body: Death, Femininity and the Aesthetic. Manchester: Manchester University Press.

Dash, I.G. 1997. Women's Worlds in Shakespeare's Plays. London: Associated Universities.

Detmer-Goebel, E. 2001. "The Need for Lavinia's Voice: Titus Andronicus and the Telling of Rape" in C. Barroll (ed.). Shakespeare Studies. London: Associated University Press, vol. XXIX.

Foucault, M. 1995. Istoria sexualităţii. Timişoara: Editura de Vest.

Gay, P. 1994. As She Likes It: Shakespeare's Unruly Women. London and New York: Routledge.

Hunt, J. 1988. "A Thing of Nothing: The Catastrophic Body in Hamlet” in Shakespeare

Quarterly, 39, 1.

Meun, J. de. 1999. The Romance of the Rose. New York: Oxford World's Classics.

Nead, L. 1992. The Female Nude: Art, Obscenity and Sexuality. London and New York: Routledge.

Percec, D. The Body's Tale. Some Ado about Shakespeare's Plays. Timişoara: Editura Universităţii de Vest.

Scarry, E. 1985. The Body in Pain: The Making and Unmaking of the World. Oxford: Oxford University Press. 


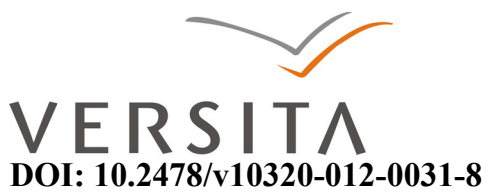

\title{
SHE'S THE MAN: GENDER DYNAMICS IN WILLIAM SHAKESPEARE'S TWELFTH NIGHT
}

\author{
ECATERINA HANŢIU \\ University of Oradea \\ 1, Universitatii Str., 410087, Oradea, Romania \\ liahantiu@yahoo.co.uk
}

\begin{abstract}
More than any other Shakespearean play, Twelfth Night demonstrates hogender can be performed and impersonated with the use of voice, costume and mannerisms. The play explores the relationship between gender and desire, allowing us to understand the complex ways in which Shakespeare responded imaginatively to sex, gender and sexuality as determinants of human identity. The article also discusses various movie versions of the play.
\end{abstract}

Key words: Elizabethan performance, gender, identity, movie versions

William Shakespeare's comedy Twelfth Night (ca. 1601-2) is an improbable but entertaining fantasy that hides beneath its merry surface some of life's deepest truths. Indeed, behind all the humour displayed in this work of genius, a major truth that is both happy and sad is expressed: life is short and full of unpleasant events, so it is our duty to recognise and cherish real happiness if it comes our way.

In Shakespeare's time celebrating Christmas only began on December $25^{\text {th }}$, the twelfth night after Christmas being January 5-6, which marked the end of the festive season with the arrival of the Wise Men in Bethlehem. Even if the theme of the play has little or nothing to do with the gifts of the Magi, it is well known that the period was one of gift-giving, partying and having fun even by breaking rules and conventions. People were allowed to play whatever roles they wanted, so that sometimes masters waited on their servants just for fun, while music, entertainment and riotous disorder were quite natural on such an occasion. The subtitle of Shakespeare's play is What You Will, which 
may be a reference to free options and choices as fit for the occasion, rather than reflecting condescension.

It is obvious that in order to enjoy the play we must accept some impossible situations and use our willpower to change Shakespeare's land of make-believe into a real world. For instance, we must pretend that successful long-term relationships and lasting happiness can occur even in cases of mistaken identity, and we must strongly believe that fraternal twins of opposite sexes, dressed identically, are indistinguishable. We must also accept Illyria, the setting of Twelfth Night, as a real country, although it is obvious that it is important for the play's romantic atmosphere and nothing more. Illyria may have been suggested by the Roman comedy Mencechmi, the plot of which involves a pair of twins who are mistaken for each other like Shakespeare's Sebastian and Viola, but the play's setting has several Elizabethan English characteristics. For instance, the cry of $16^{\text {th }}$ century London boatmen is used in the play by Viola:

Then westward, ho! Grace and good disposition 'tend your ladyship! (Act 3, Scene I, 66),

while The Elephant, a pub not far from the Globe Theatre, is recommended by Antonio to Sebastian as the best place to lodge in Illyria:

In the south suburb, at the Elephant, Is best to lodge. (Act 3, Scene III, 67)

However, in this comedy, just as in some other Shakespearean plays such as $A$ Midsummer Night's Dream,, space is irrelevant. Shakespeare's Illyria is but an illusion, just like Duke Orsino's falling in love with Olivia (which is actually falling in love with the idea of love) or Olivia's falling in love with Cesario (who is not a man, but Viola, a woman in disguise).

Viola and her twin brother, Sebastian, are separated as their ship sinks and reunited only later after having passed through various unusual situations. The play actually focuses on mistaken identity, but unlike in Shakespeare's Comedy of Errors, where the errors are purely fortuitous, as nature alone has conspired to ridicule human complacency, in Twelfth Night Viola intentionally disguises herself as a man and takes the name of Cesario. Her twin brother, Sebastian, is also mistaken for Cesario, but only at 
the end of the play. In both plays, the doppelgängers come out of the sea, the supreme Shakespearean symbol of mysterious uncontrollable nature, as the result of an accident, a shipwreck: it is Nature that has arranged for two people to look so alike, it is Nature again that separates them and later on reunites them. But in Viola's case, one can observe the way in which human will interferes with Nature's pranks. The theatrical device of mistaken identity that Shakespeare used so deftly in his Comedy of Errors takes on a more realistic shape in Twelfth Night: the mistakes are caused by intentional disguise. Viola's disguise as a man, besides contributing to the complexity of the plot, seems to convey additional messages as well, by suggesting that sexes are arbitrary and women are just as resourceful as men in finding a way to solve problems.

Viola arrives at the palace of Duke Orsino of Illyria disguised as Cesario and soon (s)he becomes indispensable to the Duke, who regards this charming young courtier as his confidante and messenger to the fair Olivia, the lady the Duke is fond of.

As women could not perform on the Elizabethan stage, Viola's part had to be played in those days by a young man, which made disguise much easier. Almost every human society throughout history has made distinctions between male and female gender by the type of clothing they were expected to wear, and most societies have had a set of norms or even laws defining what type of clothing was appropriate for each gender. The Elizabethan era was a period of time dominated by class structure, with the consequemce that people were not allowed to dress as they liked. They had to obey the so-called Sumptuary Laws, dictating the kind of clothing people had to wear according to rank, status or social position. For instance, the English Sumptuary Law of 1574 (The Statutes of Apparel) stated the following:

Note that also the meaning of this order is not to prohibit a servant from wearing any cognizance of his master, or henchmen, heralds, pursuivants at arms; runners as jousts, tourneys, or such martial feats, and such as wear apparel given them by the Queen, and such as shall have license from the Queen for the same. (http://www.elizabethan-era.org.uk/elizabethan-costume.htm)

The clause applied to actors and their costumes too. Historical realism was to come as late as the $19^{\text {th }}$ century, so on the Elizabethan stage, whatever the play and whichever era the play was set in, the actors wore the costumes of their own time. 
Different coloured clothing, the types of materials and fabrics (velvet, silk, lace, cotton and so on) represented codes the meanings of which could be easily deciphered by the audience. For example, yellow was associated with envy, greed and treachery - this is why Olivia is so shocked to see Malvolio wearing the yellow stockings and crossed garters recommended to him by drunken Sir Toby and the clever Maria, who together engineer his downfall.

The distinction between men and women in the way of clothing helped the young male actors of the time to successfully impersonate women on the stage. Cross-dressing, which was used as a sign of protest by a number of emancipated $19^{\text {th }}$ century women, did not in this case reflect a rebellious countering of norms; on the contrary, it meant obeying the rules of performance making, especially when the play dealt with mistaken identities.

The concept of mistaken identity is doubled in this play in a more complex way and on a different level than in The Comedy of Errors, in which two pairs of male twins contribute to creating the imbroglio; Shakespeare sticks to just one set of twins in Twelfth Night, but by making Viola disguise herself as a man, he establishes a second kind of mistaking identity: the other characters in the play mistake Viola for a man, and later they mistake Sebastian for Viola/Cesario. Gender ambiguities are inherent in the play's crossdressing. Viola's disguise places her in confusing situations: on the one hand she falls in love with Orsino and cannot reveal her true feelings, as he treats her as a man, and on the other hand beautiful Olivia falls in love with Viola/Cesario at first sight, also mistaking her for a man.

As Viola has put on a mask to create another self, she cannot give up her disguise, even though she feels sorry for deceiving Olivia while experiencing personal distress of the same kind. Viola/Cesario tries to behave like a man, and although she is described by Malvolio as "not old enough for a man, nor young enough for a boy" (Act 1, Scene V, 59), (s)he knows how to obtain what (s)he wants.

Still, in comparison with other Shakespearean women in disguise, such as Portia in The Merchant of Venice or Rosalind in As You Like It, who seem to be completely comfortable in their impersonations and always in control, Viola is more vulnerable, more hesitant. Sometimes she seems very boyish, but there are times when there is some awkwardness in her trying to fill the role that she has to play, just as there are cases when 
Viola/Cesario behaves like a woman. During her first encounter with Olivia she refers to her assumed identity and suggests that she is playing a role:

OLIVIA: Are you a comedian?

VIOLA/CESARIO: No, my profound heart: and yet, by the very fangs of malice, I swear, I am not that I play. (Act 1, Scene V, 60)

As Olivia has previously covered her face with a veil, Viola's female curiosity can no longer be repressed. It is both the curiosity of any woman and that of a woman in love, who needs to see the face of her rival and compare it with her own, that makes her quite abruptly ask Olivia to let her see her face. Under any other circumstances, Olivia would have regarded Viola's behaviour as suspicious, but apparently she is already too fascinated by the looks and the voice of the young messenger to hesitate, especially as she takes Cesario's request as the proof of his interest in her.

VIOLA: Good Madam, let me see your face.

OLIVIA: Have you any commission from your lord to negotiate with my face?

You are now out

of your text: but we will draw the curtain and shew you the picture. (Act 1,

Scene V, 60)

Olivia has long been accustomed to the admiration of men and expects to receive compliments praising her attractive looks, yet she hears something quite unexpected from Viola/Cesario, who - like a jealous woman - doubts the natural quality of Olivia's beauty, suspecting a counterfeited beauty.

OLIVIA: Look you, sir, such a one as I was, this presents: Is't not well done?

(Unveiling)

VIOLA: Excellently done, if God did all. (Act 1, Scene V, 60)

The discourse then takes a rapid shift from female maliciousness to the seriousness of a messenger's duty, the flattery of euphemistic talk replacing the venom of envy, because Viola is honest enough to admit that she is in the presence of true, genuine 
beauty and Cesario has a message to deliver. Viola/Cesario recites a text that conforms to all the conventional codes of courtly manners, including admiration for the lady's beauty and praise of her virtue under the form of a complaint about her cruelty, to which the well-known Shakespearean idea of transmitting beauty to the next generations is added, just as in his so-called procreation sonnets (Sonnets 1 to 17):

\footnotetext{
VIOLA: 'Tis beauty truly blent, whose red and white

Nature's own sweet and cunning hand laid on;

Lady, you are the cruel'st she alive,

If you will lead these graces to the grave,

And leave the world no copy. (Act 1, Scene V, 60)
}

The idea of same-sex attraction and gender blending, presented in a roundabout way that makes some of Shakespeare's sonnets cryptic, is a characteristic of this play too. Olivia feels an irresistible attraction for Viola/Cesario, in spite of the latter's numerous warnings, while Duke Orsino is continually demanding to have Cesario by his side, in spite of his declared love for Olivia. At the end of the play each of them actually gets the correct version of the same person, as the twins are described as indistinguishable:

ANTONIO: An apple, cleft in two, is no more twin

Than these two creatures. Which is Sebastian? (Act 5, Scene 1, 60)

The relationship between Sebastian and Antonio, which has often been neglected and placed in the background of Viola's relationship with Orsino, is also interesting and somewhat confusing. Antonio had saved Sebastian's life, and his deep affection is expressed in words that reveal feelings deeper than mere friendship:

ANTONIO: That most ingrateful boy, there, by your side,

From the rude sea's enrag'd and foamy mouth

Did I redeem: a wreck past hope he was;

His life I gave him, and did thereto add

My love, without retention or restraint,

All his in dedication: for his sake,

Did I expose myself, pure for his love, 
Into the danger of this adverse town; $[\ldots]$

And for three months before

(No interim, not a minute's vacancy),

Both day and night did we keep company. (Act 5, Scene 1, 73)

The emotional language in which he describes Sebastian, and his anger at his betrayal, have led some commentators to suggest that there is a homoerotic attachment between the two characters - at least on Antonio's side.

ANTONIO: If you will not murder me for my love, let me be your servant.

SEBASTIAN: If you will not undo what you have done - that is kill him whom you have recovered - desire it not. (Act 2, Scene I, 61)

Other commentators have criticised this attempt to impose $20^{\text {th }}$ century sexual and emotional categories on the world of Renaissance drama. They argue that Antonio's impassioned expressions of friendship do not have any suspicious connotations, and that the relationship between these men is nothing but an example of the strong and celebrated tradition of close male comradeship in the English Renaissance. It is suggestive, however, that Antonio's demand let me be your servant sounds like the courtly love rhetoric of lover as servant which Petrarchan love poetry had popularised. (http://jembloomfield.suite101.com/antonio-in-twelfth-night-a29871)

Antonio is apparently taken with Sebastian as an epitome of Renaissance beauty, a handsome youth, still uncertain about his tastes, feelings and/or sexual orientation. The beauty of Olivia appears so striking to Sebastian that he consents to marry her on the spot, without thinking twice. One of Shakespeare's favourite themes, the difference between appearance and reality, finds suitable illustration in Sebastian, who is quick to judge by appearances. Compared with her brother, Viola is a determined young woman who knows what she wants - and she wants to become Orsino's wife; still, when Malvolio tries to describe the disguised Viola to Olivia, he uses words which seem to describe not only an adolescent but also an androgynous person.

Viola and Sebastian may look very much alike, but their behaviour and ways of thinking are different. Viola is a clever, resourceful and independent person who 
deliberately disguises herself in order to protect herself and preserve her freedom. She never abandons hope and thinks of her brother as having been saved from drowning, just like herself.

VIOLA: And what should I do in Illyria?

My brother he is in Elysium.

Perchance he's not drown'd; - What think you, sailors?

CAPTAIN: It is perchance that you yourself were saved.

VIOLA: O, my poor brother! And so, perchance may he be. (Act 1, Scene II,

57)

By contrast with his sister, Sebastian is less optimistic and has lost all hope that Viola may be alive, so he sheds bitter tears when he thinks of her.

SEBASTIAN: [...] my stars shine darkly over me; the malignancy of my fate might, perhaps, distemper yours $[. .$.$] some hour before you took me from the breach of the sea, was my sister$ drowned. [...] she is drowned already, sir, with salt water, though I seem to drown her rememberance again with more. (Act II, Scene 1, 61)

$\mathrm{He}$ is also an accommodating character. This is why he needs the protection of a mature friend like Antonio and then submits to Olivia's decision that they should be married. Olivia, as suggested by Jean Howard in her Crossdressing, the Theater, and Gender Struggle in Early Modern England, is in a way a masculinised woman. Olivia, she writes,

is a woman of property, headstrong and initially intractable, and she lacks any discernable male relatives $[\ldots]$ to control her or her fortune (Howard, 1988: 432).

Seen in this light, Olivia appears to be the dominant presence in her relationship with Sebastian, just as Antonio had been in his relationship with the youth. The ambiguous words Sebastian uses when telling Olivia:

You are betrothed both to a maid and a man (Act 5, Scene 1, 74) 
may also be interpreted as him acknowledging that he has had a passionate relationship with Antonio. This is the last line Sebastian speaks in the play, a cryptic statement that sounds like a warning, presaging a questionable domestic atmosphere.

Beautiful and sweet as she might seem, Olivia is very much like Viola, a woman of action, strong-willed, intelligent and capable of taking care of herself. Both Olivia and Viola fight for what they want, leaving contemplative meditation to men like Orsino and Sebastian.

Just like Sebastian, Orsino - who is older but none the wiser - readily agrees to marry Viola/Cesario, without even having seen her in her maiden's weeds, while the words he utters upon making such a hasty decision sound as cryptic as Sebastian's:

[...] Cesario, come:

For so you shall be, while you are a man:

But when in other habits you are seen,

Orsino's mistress and his fancy's queen. (Act 5, Scene 1,75)

Orsino's love declaration is rather bizarre or at least strangely phrased, as he continues to address Viola by her assumed male name, even after her true identity is revealed. He never calls her by her real name, continuing to recognise Cesario as a legitimate identity for his future wife. A possible continuation of the disguise in their home is alluded to, in which Viola, dressed up as a woman, would meet the expectations of Orsino's desire to have a mistress.

The complexity of the play has always been regarded as making it challenging for actors, stage and movie directors - hence the large number of performances given all over the world, as well as the numerous adaptations of it for the stage, the silver screen, radio and television. It is interesting to observee that in all cases the stage and/or movie directors have chosen actresses to perform the double role of Viola and Sebastian, that some of the very best actors and actresses have tried to match up to the demands imposed by the mix-ups of the comedy, and that some of themost lasting achievements in this genre are still regarded as great movies today. 
A short silent adaptation was released by the Vitagraph Studios as early as 1910, with Florence Turner playing the part of Viola.

The 1996 Twelfth Night movie directed by Trevor Nunn and adapted to be set in the 19th century employed a group of excellent actors, including Imogen Stubbs as Viola, Helena Bonham Carter as Olivia, Toby Stephens as Duke Orsino and Ben Kingsley as Feste, the Clown. The film also features Mel Smith as Sir Toby, Richard E. Grant as Sir Andrew, Imelda Staunton as Maria and Nigel Hawthorne as Malvolio.

The Shakespearean spirit is present in spite of the $19^{\text {th }}$ century setting, with references to swords and other weapons being carefully preserved and strengthened by the assumed military ranks of the male characters. The movie director's vision is rather a gloomy one, as observed by Peter Holland in an article entitled "The Dark Pleasures of Trevor Nunn's Twelfth Night", published in the Shakespeare Magazine:

The darkness of the play is palpable on screen. It is there not just in the gloomy autumnal landscape of the film's world but also in the oppressive interiors of the buildings. Viola transforms Olivia's house from a house of mourning by the simple expedient of opening the curtains to let light flood in. It is also there in the militarism of Orsino's kingdom, where soldiers chase Antonio when he is recognized, and where the shipwrecked Viola and sailors scurry for cover when a troop of Orsino's horsemen investigate the debris of the wreck on the seashore. (http://www.shakespearemag.com/spring97/12night.asp)

As a specialist in staging Shakespeare, Peter Holland (Director Designate of the Shakespeare Institute, Stratford-upon-Avon, England) observes that Trevor Nunn's choice of the $19^{\text {th }}$ century for his movie was dictated by the fact that this was the most relevant period for gender contrast in all respects: clothes, attitudes, and interpersonal relationships.

\footnotetext{
Nunn has chosen to set the film in a 19th-century Illyria (actually mostly filmed in Cornwall) because it is a world where the gender gap is strongly seen both in the extreme contrast of clothing (Nunn calls it "the dress silhouettes") and in social attitudes. It is a society where the class structures of the play's world are immediately comprehensible, where it is genuinely transgressive for Maria, Olivia's servant, to marry Sir Toby, Olivia's kinsman, and where Malvolio's final public humiliation is all the more painful for being witnessed by the servants over whom he would normally have had authority. (http://www.shakespearemag.com/spring97/12night.asp)
} 
The efforts Viola makes in order to get into not only the shape of a young man but also the world of men, which are never clearly revealed by Shakespeare, are made obvious in the movie and can be visualised in detail:

\begin{abstract}
But, above all, the choice of period makes clear and powerful the journey Viola has to make. Nunn shows Viola changing her silhouette into Cesario's: cutting her hair, binding her breasts, putting on men's clothing. But she then has to negotiate the world of male activity: she must relearn how to walk or how to yawn and learn new skills like fencing or, most awkwardly for her, how to have a conversation with her master while Orsino is in the bath. The distance she travels to make that transformation is clear, and the profundity of its effects on her and on all who come into contact with her is equally striking. (http://www.shakespearemag.com/spring97/12night.asp)
\end{abstract}

Shakespeare in Love (1998), directed by John Madden and written by Marc Norman and the playwright Tom Stoppard, contains several references to Twelfth Night. It is a charming story which attempts to put together an imaginary account of the period in which the young Shakespeare, lacking money and suffering from writer's block, is trying to write Romeo and Juliet. Against this background of writing about love and desperate lovers, he meets Viola, the daughter of a wealthy merchant, a strong-willed and independent young woman, who disguises herself as a boy to become an actor in spite of all restrictions, and she becomes his true Muse. Near the end of the movie, Queen Elizabeth I (Judi Dench) asks Shakespeare (Joseph Fiennes) to write a comedy for the Twelfth Night holiday, which he starts with Viola (Gwyneth Paltrow) on his mind.

One of the most interesting recent adaptations is Andy Fickman's 2006 film She's the Man, which modernises the story as a contemporary American teenage comedy (as 10 Things I Hate About You did with The Taming of the Shrew). It is set in an American prep school named Illyria where Duke Orsino (Channing Tatum) is sharing his room on the campus with the newly arrived Sebastian Hastings (Amanda Bynes). In fact the Duke's new room-mate is Viola, Sebastian's twin sister, whose girls' soccer team has just been disbanded and who desperately wants to play in order to beat the Cornwall team and humiliate her ex-boyfriend, Justin. While Viola is playing soccer with the boys, she is 
also covering for Sebastian (James Kirk), who has gone to a music contest in London with his new band.

Unlike Viola, who is a fine athlete and very good at playing soccer, Sebastian is a romantic boy, fond of music and poetry. When he meets Olivia (Laura Ramsey) for the first time he is impressed not only by the passionate kiss he receivess from her but also by finding out that this girl can recite his poems.

Besides using the Shakespearean device of making the fake Sebastian the Duke's friend and confidante, the movie director also included here the "courtship rehearsal" employed in As You Like It, when Rosalind/Ganymede pretends to counsel Orlando to cure him of being in love.

Amanda Bynes as Viola/Sebastian is simply charming, if not always convincing. In a much sunnier atmosphere than that of Trevor Nunn's movie, the American Viola binds her breasts, tries on wigs and make-up, men's $\mathrm{T}$ shirts, blue jeans and suits. Disguise in itself not being enough for this modern background, the young girl freely uses boyish gestures and language in order to make her campus-Sebastian more credible. She follows various men in the street, trying to imitate their movements and gestures, with her efforts at times resulting in ridiculous situations. Extra help is provided by adding to the cast a couple of Viola's friends who pretend to be dumped girlfriends, to increase Sebastian's credibility as a ladykiller among his dorm mates. Shifting roles in a hurry, Viola tries to run around and do both her and her brother's jobs at the Junior League carnival, performing a genuine tour de force, dressing and undressing, changing places, avoiding in turn her mother and Monique, Sebastian's ex-girlfriend and managing to fool both of them. In expanding the basic premise and adding comedic elements, the movie director used both Mack Sennett chase elements and the snowball effect, common clichés in cartoons and modern theatrics.

The American Viola is a real tomboy, although she is supposed to be and behave like a Southern belle. Her behaviour at the course for débutantes is outrageous, shocking and even disgusting (on purpose) at times. She hates the artificial pretended delicate feminine gestures taught there and protests by entering the room at a totally ungraceful pace and by eating in a distasteful manner. The course is a fiasco, culminating in Viola, Olivia and Monique fighting in the restroom in a most unladylike way. 
Sebastian/Viola succeeds in playing soccer with the boys, her team is victorious, and the game ends with the Duke quoting the words of Malvolio in Shakespeare's play:

Be not afraid of greatness. Some are born great, some achieve greatness and some have greatness thrust upon them. (Act 2, Scene V, 65)

The final part of the movie takes everybody to the débutante ball where Olivia comes in accompanied by the real Sebastian and Viola - finally agreeing to wear a dress - has the Duke as her formal date.

Although inspired by Shakespeare's Twelfth Night, She's the Man is a much lighter version of the story, in which it is entertainment and not serious considerations about life and its problems that comes first. Some of the important characters in Shakespeare's play (Sir Toby, Andrew Aguecheek, Maria, Feste etc) are merely shadowy presences in the movie, acting as necessary but not indispensable class or dorm mates, while Malvolio simply becomes Malcolm, Feste's pet: a hairy tarantula. Much of Shakespeare's philosophical thought and wit is in this way lost, the intention of the producer being directed towards providing amusing situations and images instead of entertaining but at the same time deep dialogues.

Nevertheless, the main message of this Shakespearean romantic comedy is still there: love comes in various shapes, love means trouble and pain - or, as the Duke puts it in the movie: when you're in love you have issues, but love can also be the most beautiful thing in the world. Moreover, unless we experience a certain situation, we do not know what it is like; unless we walk in somebody else's shoes we don't know what he/she really feels. Shakespeare's comic, romantic tale of loss and love, disguise and gender continues to teach wise life lessons, no matter what shape it comes or will come in.

\section{References}

Howard, J. 1988. "Crossdressing, the Theater, and Gender Struggle in Early Modern England" in Shakespeare Quarterly 39, pp.418-40. Jenkins Logan, T. 1982. Twelfth Night: The Limits of Festivity. Studies in English Literature, 1500-1900, Vol. 22, Nr.2, Elizabethan and Jacobean Drama, Spring 982, pp.223-238. 
Kott, J. 1974. Shakespeare Our Contemporary. New York: W. W. Norton \& Company.

Shakespeare, W. 1993. Twelfth Night in The Complete Works of William Shakespeare.

London: Ramboro Books.

\section{Webography}

http://www.elizabethan-era.org.uk/elizabethan-costume.htm

http://jembloomfield.suite101.com/antonio-in-twelfth-night-a29871

Holland, P. The Dark Pleasures of Trevor Nunn's "Twelfth Night”, Shakespeare

Magazine, [Online]. Available:

http://www.shakespearemag.com/spring97/12night.asp

\section{Movies}

Twelfth Night (1996) Director: Trevor Nunn Writers: William Shakespeare (play), Trevor Nunn (screenplay). Stars: Helena Bonham Carter, Richard E. Grant, Imogen Stubbs, Steven Mackintosh.

Shakespeare in Love (1998) Director: John Madden Writers: Marc Norman, Tom Stoppard. Stars: Gwyneth Paltrow, Joseph Fiennes, Colin Firth, Geoffrey Rush, Judi Dench.

She's the Man (2006) Director: Andy Fickman, Writers: Ewan Leslie (story and screenplay), Karen McCullah Lutz (screenplay), Kirsten Smith (screenplay). Stars: Amanda Bynes, Laura Ramsey, Channing Tatum, James Kirk 


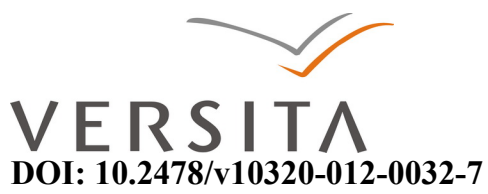

\title{
LADIES AND GENTLEMEN IN RENAISSANCE WESTERN EUROPE EROS VIA THANATOS
}

\author{
ELISABETA ZELINKA
}

West University of Timișoara, 4, Pârvan Blvd, Timișoara, Romania

elisabeta_zelinka@yahoo.com

\begin{abstract}
The present article offers a postmodern (re)interpretation of the $16^{\text {th }}$ century Renaissance set of social etiquettes versus the average citizen's Weltanschauung triggered by his most natural drives and impulses. The epicentral focus of our investigation is the social network(s) built by the different, sometimes oppositional ethical, theological and epistemological codes. What types of motivation triggered certain members of different social layers to observe or to break these codes? Was there any differentiation between clergymen and (fe)male aristocracy? Most importantly, why was the epistemological positionality of men different from that of (educated) women?
\end{abstract}

Keywords:collective consciousness, the French Revolution, "the politics of location", proto-liberation, Weltanschauung

\section{Introduction: Elizabethan phallocratic realities}

William Shakespeare presents the ravishing love story unfolding between the scions of two rival families in Verona: the Montagues and the Capulets. The Bard probably had little idea that the Romeo and Juliet motif would live as long as $21^{\text {st }}$ century cinema and drama, and appear over the signature of world-famous directors and actors: West Side Story, Romeo and Juliet, Shakespeare in Love. This love-related motif can be considered to be more deeply engraved in the collective conscience of the postmodern audience (whether as readers or viewers) than any other. 